\title{
EDIOVANI ANTÔNIO GABOARDI
}

$$
\begin{aligned}
& \text { A FENOMENOLOGUA } \\
& \text { ESPIRITOO DE LIEGEL }
\end{aligned}
$$

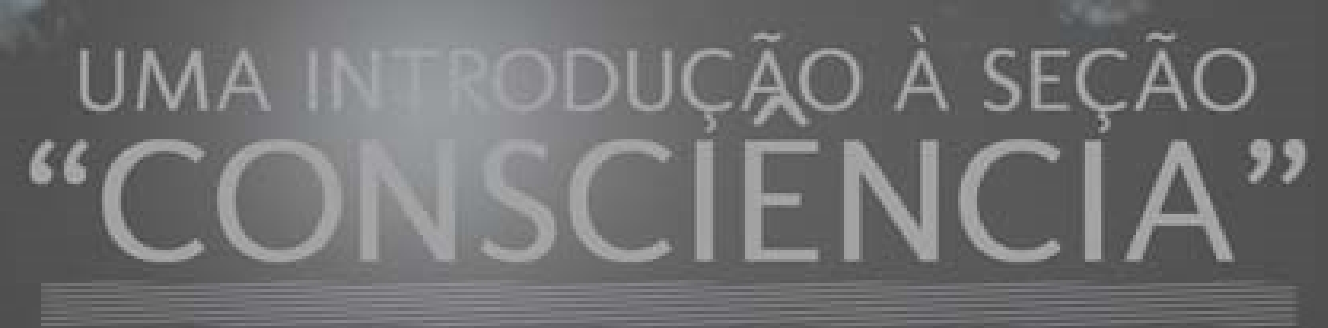




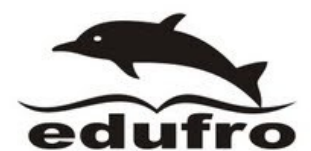

Editora da Universidade

Editora da Universidade
Federal de Rondônia
Campus Jose Ribeiro rılno

Campus Jose Ribeiro FIlno

CEP: $78900-000$

www.edufro.unir.br

edufro.unir@gmail.com 
Ediovani Antônio Gaboardi

\begin{abstract}
A FENOMENOLOGIA DO ESPÍRITO DE HEGEL:
UMA INTRODUÇÃO À SEÇÃO "CONSCIÊNCIA"
\end{abstract}

$1^{\circ}$ Edição

EDUFRO

Porto Velho - RO, 2013 
G116f Gaboardi, Ediovani Antônio

A fenomenologia do espírito de Hegel: uma introdução à seção "consciência" / Ediovani Antônio Gaboardi. Porto Velho-RO: EDUFRO, 2013.

$130 \mathrm{p}$.

ISBN 978-85-7764-059-1

1. Hegel 2. Fenomenologia 3. Consciência I. Titulo

CDU: 165.2

Bibliotecária Responsável: Ozelina Saldanha CRB 11/947

Preparo de originais: Autor(es)

Revisão Gramatical: Autor(es)

Revisão de Normas Técnicas: Autor(es)
Capa: Ícaro Santana

Composição: EDUFRO

Editor: Jairo André Schlindwein

Fundação Universidade Federal de Rondônia

\author{
Maria Berenice Alho da Costa Tourinho \\ Reitora \\ Maria Cristina Victorino de França \\ Adilson Siqueira de Andrade \\ Chefe de Gabinete \\ Ivanda Soares da Silva \\ Pró-Reitor de Administração
}

\author{
Osmar Siena \\ Pró-Reitor de Planejamento \\ Jorge Luiz Coimbra de Oliveira \\ Pró-Reitora de Graduação \\ Ari Miguel Teixeira Ott \\ Pró-Reitora de Pós-Graduação e Pesquisa \\ Rubens Vaz Cavalcante
}

Pró-Reitor de Cultura, Extensão e Assuntos Estudantis

Conselho Editorial da EDUFRO:

Jairo André Schlindwein (Prof. UNIR), José Lucas Pedreira Bueno (Prof. UNIR), Emanuel Fernando Maia de Souza (Prof. UNIR), Rubiani de Cássia Pagotto (Profa. UNIR), Osmar Siena (Prof. UNIR), Júlio César Barreto Rocha (Prof. UNIR), Marli Lucia Tonatto Zibetti (Profa. UNIR), Sirlaine Galhardo Gomes Costa (Bibliotecária. UNIR), Cléberson de Freitas Fernandes (EMBRAPA), Dante Ribeiro da Fonseca (ACLER).

Depósito legal na Biblioteca Nacional conforme Lei $\mathrm{n}^{\circ}$ 10.994, 14 de dezembro de 2004.

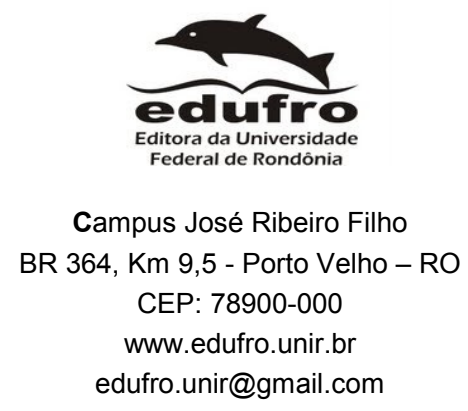




\section{SUMÁRIO}

Página

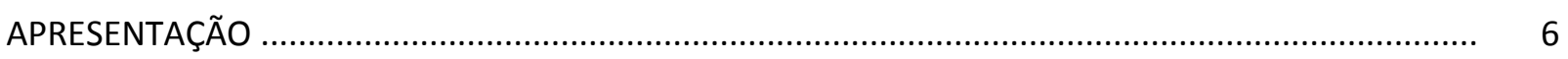

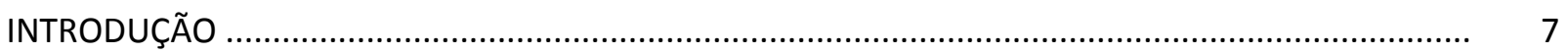

CAPÍTULO I - A CRÍTICA A KANT NOS ALICERCES DA FENOMENOLOGIA ….................................. 8

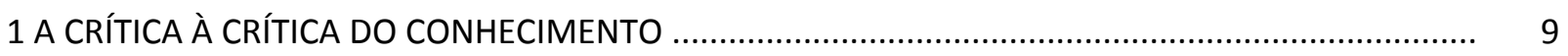

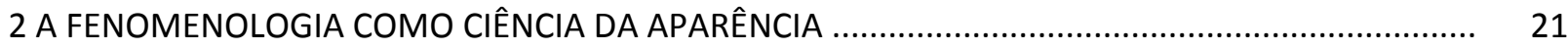

3 A ESTRUTURA DA CONSCIÊNCIA COMO BASE DA CRÍTICA ….................................................... 27

CAPÍTULO II - A AUTOCRÍTICA DA CERTEZA SENSÍVEL ...................................................................

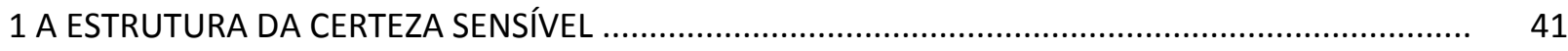

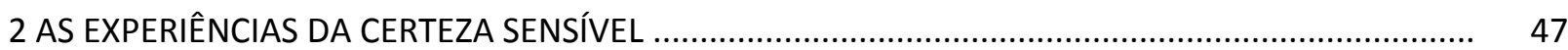

CAPÍTULO III - A AUTOCRÍTICA DA PERCEPÇÃO …......................................................................... 55

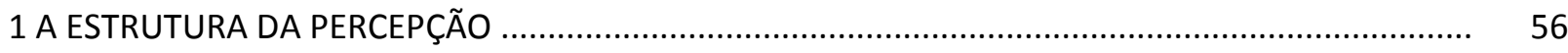

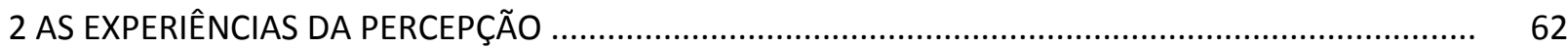

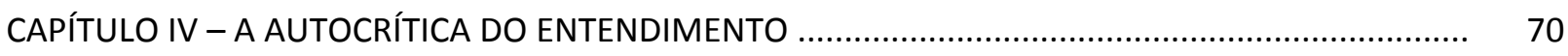

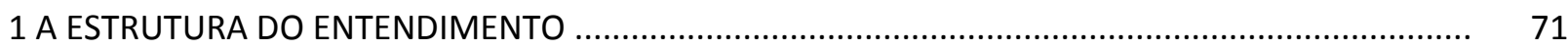

2 AS EXPERIÊNCIAS DO ENTENDIMENTO COM A FORÇA …..................................................... 80

3 AS EXPERIÊNCIAS DO ENTENDIMENTO COM O SUPRASSENSÍVEL …............................................ 93

4 AS EXPERIÊNCIAS DO ENTENDIMENTO COM O REINO DAS LEIS .............................................. 101

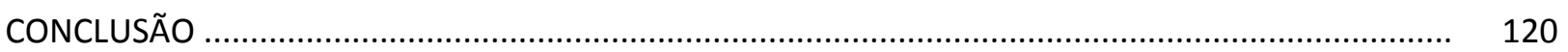

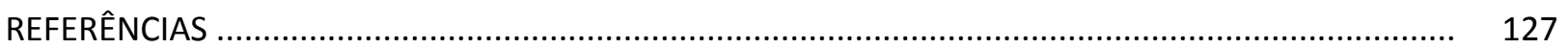




\section{APRESENTAÇÃO}

Este trabalho se destina a estudantes de filosofia que estejam vivenciando a difícil tarefa de ler e interpretar uma das obras mais densas e complexas do pensamento ocidental: a Fenomenologia do espírito de Hegel. Portanto, seu propósito não é oferecer uma interpretação nova, nem desenvolver uma leitura particular baseada em algum problema filosófico específico.

Por outro lado, não se faz aqui uma apresentação das fontes teóricas do pensamento hegeliano, nem um trabalho filológico ou ainda histórico. Também não se pretende oferecer uma visão sintética e ampla sobre as principais teses do autor. Todas essas abordagens estão mais ou menos disponíveis, embora em língua portuguesa haja ainda muito espaço a ser preenchido.

Nesta obra, buscar-se-á fazer aquilo que o próprio Hegel estabelece como prioridade ao filosofar: entregar-se ao conceito. Assim, a pretensão aqui é reconstruir a argumentação de Hegel, tentando interpretá-la a partir das referências que ele mesmo oferece ao longo do texto.

Talvez uma exceção deva ser considerada. No primeiro capítulo, em que se tematiza a introdução da Fenomenologia do espírito, adota-se como hipótese de leitura a ideia segundo a qual o modelo de filosofia criticado por Hegel ao longo do texto é o kantiano. Essa hipótese será importante apenas na medida em que serve para definir as experiências pelas quais passam as três figuras da consciência analisadas - a certeza sensível, a percepção e o entendimento - como formas de autocrítica, tornando Hegel um continuador (crítico) da filosofia crítica.

Com este trabalho, espera-se contribuir para a compreensão deste autor tão fundamental para diversas correntes de pensamento contemporâneas. 


\section{INTRODUÇÃO}

O presente trabalho tenta ler Hegel à luz da filosofia moderna. Certamente, a filosofia deste autor representa um marco singular na história do pensamento ocidental. É evidente que muitas das questões tratadas por ele, como ele mesmo admite, têm origem em outros pensadores. Entretanto, nenhum deles levou tão a sério a tarefa de fazer da filosofia um edifício sistemático capaz de, por um lado, abarcar coerentemente todo saber humano e, por outro, estabelecer seus fundamentos. Talvez seja justamente a grandiosidade das pretensões dessa filosofia a causa das maiores dificuldades daquele que quer compreendê-la.

Busca-se aqui encontrar a problemática basilar da filosofia hegeliana. Acredita-se que isso pode ser alcançado a partir da investigação da primeira obra de seu sistema filosófico - a Fenomenologia do espírito. Além disso, pensa-se que o que está em jogo aí é, antes de tudo, um conjunto de elementos surgidos a partir da crítica de Hegel a Kant. A partir desses elementos, portanto, deve ser possível criar as condições para se expor, de modo adequando, as linhas gerais da filosofia hegeliana, ao menos no que diz respeito à Fenomenologia.

A crítica de Hegel a Kant é apresentada aqui a partir do modo como ela é desenvolvida na introdução da Fenomenologia. Esse passo corresponde ao primeiro capítulo do trabalho. Em seguida, tenta-se reconstruir a argumentação de Hegel no próprio interior da Fenomenologia. Isso é feito através na interpretação de seus três primeiros capítulos dedicados à consciência, que abordam a Certeza sensível, a Percepção e o Entendimento. Compõem-se, assim, o segundo, o terceiro e o quarto capítulos deste trabalho. 
CAPÍTULO I

A CRÍTICA A KANT NOS ALICERCES DA FENOMENOLOGIA 


\section{A CRÍTICA À CRÍTICA DO CONHECIMENTO}

Neste primeiro capítulo, apresentar-se-á um estudo da introdução da Fenomenologia do espírito de Hegel. Este estudo está dividido em três seções: em primeiro lugar, a crítica à crítica do conhecimento; em segundo, a fenomenologia como ciência da aparência; e, for fim, a estrutura da consciência como base da crítica. O fio condutor desta investigação é a hipótese segundo a qual as críticas endereçadas por Hegel à filosofia crítica são articuladas enquanto decorrência do projeto de fundamentação do saber, construído no interior dessa mesma filosofia.

Nesta primeira seção, abordaremos a reconstrução hegeliana das teses essenciais da filosofia crítica, sua crítica a essas teses e as conclusões que dela deriva, interpretadas aqui enquanto radicalizações do projeto crítico de fundamentação do conhecimento.

\subsection{0 diagnóstico de Hegel sobre a filosofia de seu tempo}

Hegel inicia a introdução da sua Fenomenologia do espírito fazendo uma observação a respeito da filosofia de seu tempo. Segundo ele, era aceita como uma consideração natural a ideia de que a filosofia, para ser rigorosa, antes de tratar diretamente da verdade, deveria estudar as condições por meio das quais ela é contemplada ou dominada. Ou seja, à filosofia, como conhecimento do real, dever-se-ia antepor um estudo das condições do próprio conhecer, inscritas na natureza do sujeito. Como se pode ver, Hegel refere-se aqui basicamente à filosofia crítica de Kant.

Para Hegel, essa tarefa crítica justificava-se por dois motivos. Em primeiro lugar, porque, diante da existência de saberes diversos, era necessário estabelecer critérios a partir dos quais a eleição dos mais idôneos poderia ser realizada. Em segundo, porque, considerando o fato de que as faculdades cognitivas têm espécie e âmbito determinados, só mediante 0 estabelecimento de seus limites poder-se-ia conhecer o modo legítimo de proceder, em que a verdade, ao invés do erro, é alcançada (Cf.: FE' ${ }^{1}$, p. 63, § 73). Em outras palavras, Hegel pensa ter encontrado na filosofia de seu tempo duas características básicas: 0

\footnotetext{
${ }^{1}$ Por ser mais prático, usar-se-á a sigla "FE" para designar a obra hegeliana Fenomenologia do espírito (Trad. de Paulo Meneses. Petrópolis: Vozes, 1992. v. I e II). O número do parágrafo segue a classificação feita pelo tradutor, já que o original não apresenta numeração.
} 
propósito radical de encontrar uma base segura ao saber e a decisão de buscar essa base a partir da análise das estruturas cognitivas do sujeito (em sentido universal ${ }^{2}$ ).

Depois de fazer essas observações a respeito do ponto de partida da filosofia de sua época, Hegel considera seus resultados. Na sua interpretação, essa postura acaba levando à convicção de que há uma separação radical entre o absoluto (a verdade em-si mesma) e o conhecimento ao qual o sujeito pode ter acesso. Para Hegel, isso decorre do próprio ponto de vista adotado de saída por Kant. Como afirma Hegel, "se o conhecer é o instrumento para apoderar-se da essência absoluta, logo se suspeita que a aplicação de um instrumento não deixe a Coisa tal como é para si, mas com ele traga conformação e alteração" (FE, p. 63, § 73). Ou seja, se o conhecimento depende das estruturas subjetivas, o objeto conhecido será sempre diferente da coisa em-si mesma.

A questão é que uma crítica do conhecimento, na medida em que pretende fornecer uma base segura ao saber, só é viável mediante a pressuposição de que o conhecer é um instrumento que tem certa natureza e que essa natureza é indispensável à constituição do conhecimento mesmo. Se o conhecer não fosse tomado como uma estrutura determinada (e, portanto, com certos limites) e determinante, em relação ao conhecimento, não teria sentido estudá-lo na esperança de encontrar aí algum tipo de fundamento ao saber. Mas, simultaneamente, tomar o conhecimento como dependente de tal estrutura subjetiva (determinada e determinante) significa afirmar que há necessariamente uma diferença entre o que a coisa é na sua pureza e o modo como ela é representada pelo sujeito.

\subsection{A problemática da filosofia crítica de Kant}

Embora não seja possível aqui um aprofundamento maior, é importante ao menos observar genericamente como essa questão vem à tona no próprio pensamento de Kant. Para isso, é necessário iniciar pela análise dos desafios impostos por Hume ao desenvolvimento da ciência, pois em grande medida é em resposta a eles que a crítica de Kant é desenvolvida.

Como se sabe, este filósofo tentou demonstrar que o conhecimento humano é incapaz de fundamentar relações de necessidade e universalidade, na medida em que sua base é meramente empírica. Para Hume, em primeiro lugar, não se pode conhecer nada sem antes ter passado por uma experiência correspondente. Antes de ter contato com o mundo, não há a mínima possibilidade de saber como ele vai comportar-se. Para ele,

nenhum objeto descobre jamais, pelas qualidades que aparecem aos sentidos, as causas que o produziram ou os efeitos que dele derivarão; nem a nossa razão

\footnotetext{
${ }^{2}$ Cabe lembrar que Kant não investiga propriamente os mecanismos subjetivos do conhecer, em que entrariam em jogo elementos físico-psicológicos particulares aos indivíduos. Sua questão diz respeito àqueles elementos que se deve admitir para conceber a possibilidade da constituição do conhecimento como tal. Assim, o que é determinado como subjetividade não se refere às particularidades dos indivíduos, mas somente à estrutura subjetiva que deve necessariamente estar presente na constituição de todo e qualquer conhecimento.
} 
consegue alguma vez, sem ser assistida pela experiência, fazer uma inferência acerca da existência real e da questão de fato (HUME, 1989, p.33).

Ou então:

\begin{abstract}
Apresente-se um objeto a um homem de razão e capacidades naturais muito fortes; se esse objeto for para ele inteiramente novo, não será capaz, mediante o mais rigoroso exame das suas qualidades sensíveis, de descobrir qualquer de suas causas e efeitos. Adão, ainda que as suas faculdades racionais se suponham, logo de início, totalmente perfeitas, não poderia ter inferido da fluidez e transparência da água que ela o sufocaria, ou a partir da luz e do calor do fogo que ele o consumiria (HUME, 1989, p.33).
\end{abstract}

Como se pode observar, o primeiro passo de Hume é demonstrar que só a experiência empírica pode ser fonte do conhecimento. Para isso, ele se vale da simples observação de que, antes de se ter passado por ao menos uma experiência com o objeto, não se é capaz de qualquer consideração a respeito de suas propriedades. Isso significa, para ele, que nem na razão (na forma de ideias inatas, etc.), nem no objeto (como espécies inteligíveis, etc.), estão presentes elementos que possam tornar disponível ao sujeito o conhecimento dos objetos reais. Se existissem ideias inatas, seria possível deduzir a realidade do simples pensar. Se existisse algum tipo de espécie inteligível, captada a partir da simples observação do objeto, seria possível estabelecer previamente, a partir da simples posse dessa espécie, o comportamento do objeto em todos os eventos possíveis, prescindindo da observação direta desses eventos. Para Hume, essas duas hipóteses caem por terra a partir da simples constatação de que nada se pode dizer sobre o futuro senão a partir das experiências já realizadas.

Esse primeiro passo abre caminho para um segundo. Aqui Hume considera o status que qualquer conhecimento pode almejar levando em conta a constatação de que só a experiência sensível pode ser sua fonte ${ }^{3}$. Ora, se o conhecimento tem como base apenas a experiência, não é possível fazer qualquer previsão a respeito de fenômenos no mundo. Isso porque, pela observação o que se consegue, no máximo, é o catálogo completo de tudo o que já ocorreu no passado; não é possível extrair daí nenhuma consideração sobre o futuro, porque as ligações que se estabelece entre os eventos do passado são meramente empíricas. Ou seja, o fato de que só se conhece algo sobre o mundo a partir da experiência sensível implica que, a rigor, a ligação que se faz entre os objetos e suas propriedades ou entre certos acontecimentos e seus desdobramentos não pode ter sua necessidade demonstrada. À pergunta "por que as coisas se passaram assim?" só se pode responder dizendo que "as coisas se passaram assim, porque assim mostrou a experiência". Isto é, não é possível

\footnotetext{
${ }^{3} \mathrm{Na}$ verdade, para Hume, há duas formas de conhecimento: as questões de fato e as relações de ideias. O conhecimento tem sua fonte na experiência apenas no primeiro caso. No segundo, a base é a própria mente. Entretanto, aqui não se conhece nenhum objeto existente no mundo. Trata-se apenas da relação entre ideias, como ocorre na aritmética, na geometria, etc. Hume analisa, assim, o estatuto possível do conhecimento que se refere ao mundo real.
} 
encontrar nos acontecimentos do mundo qualquer elemento que indique a razão que torna necessário que de determinadas condições resulte necessariamente determinados desdobramentos. Se o conhecimento tem como fonte a experiência empírica, a ligação que se faz entre condições e desdobramentos têm como base apenas as experiências já realizadas. Consequentemente, a causalidade, por exemplo, categoria basilar da metafísica clássica, deve ser tomada apenas como o resultado do hábito de repetidas experiências, em que um fenômeno ocorre em sequência a outro. Ao verificar que um dado acontecimento ocorre sempre após outro, toma-se o antecedente como causa e o consequente como efeito. Mas essa relação está fundada não na natureza das coisas ou numa certa estrutura conceitual. Sua base não é nada mais do que o conjunto das experiências observadas no passado. E dos fenômenos observados no passado só se sabe que aconteceram, mas não por que aconteceram. Portanto, não é possível dispor de elemento algum que torne necessário concluir que aquilo que já ocorreu vai repetir-se da mesma forma no futuro.

Kant leva a sério a conclusão de Hume. Para ele, pela simples experiência sensível não se pode alcançar necessidade e universalidade no conhecimento. Desse modo, Kant aceita a premissa de Hume, segundo a qual o conhecimento que se funda na experiência não pode ser universal e necessário. Portanto, se Kant ainda quiser demonstrar a possibilidade da ciência (conhecimento universal e necessário) deverá atacar justamente a outra premissa humeana, isto é, a afirmação de que a fonte do conhecimento é meramente empírica.

Para isso, Kant parte de um ponto de vista diferente do de Hume. Como se pôde verificar, este pensador tentou compreender o processo do conhecer e seus limites a partir da pergunta pela sua gênese. A partir desse ponto de vista, ele pôde afirmar que, na medida em que o conhecimento só aparece no sujeito depois de ele ter passado por uma experiência correspondente, esta tem de ser tomada como, além de sua fonte, seu limite. Kant, por sua vez, toma outro fato como crucial. Para ele, era notória a existência de conhecimentos seguros nas ciências da época (lógica, matemática e física) ${ }^{4}$. Então, a pergunta fundamental deveria ser esta: como tais conhecimentos são possíveis?

Quer dizer, a tarefa para Kant era saber quais seriam as condições de possibilidade de um saber universal e necessário. Ele já sabia, mediante as conclusões de Hume, que tal saber não poderia basear-se apenas na experiência empírica. Mas também sabia que ela deveria ser seu ponto de partida, pois, como o próprio Hume mostrara, nada no mundo pode ser conhecido antes de se ter passado por uma experiência correspondente.

A necessidade da experiência e ao mesmo tempo sua insuficiência, somadas à crença na solidez das ciências da época, levam Kant a formular uma inversão metodológica. Se o conhecimento tivesse de se orientar pelos objetos, não haveria como fundamentar a ciência, enquanto conhecimento universal e necessário. Então, dever-se-ia partir do ponto de vista

\footnotetext{
${ }^{4}$ A rigor, a lógica não é tomada por Kant como uma ciência, pois não trata de elementos do mundo. Aqui Kant talvez continue seguindo, de certo modo, a distinção humeana, citada acima, entre relações de ideias e questões de fato. A matemática, por outro lado, é ciência. Para Kant ela depende da intuição e, portanto, não é simplesmente relação entre estruturas lógicas.
} 
oposto, segundo o qual os objetos do conhecimento é que se orientam pelo sujeito. Dever-seia admitir, portanto, uma estrutura subjetiva anterior a todo saber propriamente constituído, pela qual o material advindo da sensibilidade seria ordenado. A necessidade e a universalidade, assim, não viriam da experiência empírica, nem tão pouco seriam frutos do mero hábito. Em todo saber científico deveria estar presente uma parte empírica e uma parte pura. Aquela diria respeito ao material diverso colhido mediante a sensibilidade. Mas essa diversidade só poderia tornar-se conhecimento através da ação de estruturas previamente existentes no sujeito. Somente através da ação dessas estruturas, o diverso da sensibilidade ganharia a forma do saber e com ela tornar-se-ia conhecimento universal e necessário.

Nesse sentido, a Crítica da razão pura de Kant pode ser tomada como a tentativa de explicitar todos os elementos que têm de estar presentes a priori no sujeito para que o conhecimento seja possível. A explicitação desses elementos serviria também de critério para julgar a legitimidade das pretensões da metafísica clássica, pois mostraria que tipo de saber é possível e que tipo está para além do âmbito de abrangência das estruturas cognitivas do sujeito racional.

\subsection{A distinção entre fenômeno e númeno}

Pois bem, estes são os elementos que o próprio Hegel pensou ter encontrado na filosofia de seu tempo. Em primeiro lugar, a tentativa de estabelecer uma base segura ao saber. Em segundo, a decisão de buscá-la através da análise das estruturas subjetivas envolvidas necessariamente na constituição de qualquer conhecimento.

Mas Hegel, conforme se mostrou anteriormente, também fizera uma consideração a respeito das conclusões da filosofia kantiana. Para ele, esse modo de pensar acabava por estabelecer uma distinção insuperável entre a coisa em-si e o conhecimento que o sujeito poderia alcançar dela. Quer dizer, na interpretação de Hegel, a filosofia kantiana era obrigada a concluir que entre o objeto mesmo e o conhecimento que se refere a ele há um abismo intransponível. Se no conhecimento constituído é preciso que haja algo que advém apenas do sujeito, portanto estranho ao objeto como tal, não se pode dizer que a coisa mesma seja conhecida. $O$ sujeito só pode ter acesso ao que é por ele mesmo constituído na ação das estruturas a priori sobre o material advindo da sensibilidade. A coisa em-si, indiferente às condições e limites do conhecer, é inacessível.

$\mathrm{Na}$ verdade, o próprio Kant, a seu modo, assume essa conclusão. Na sua Crítica da razão pura, ele afirma o seguinte.

No entanto, quando denominamos certos objetos, enquanto fenômenos, seres dos sentidos (phaenomena), distinguindo a maneira pela qual os intuímos, da sua natureza em-si, já na nossa mente contrapomos a esses seres dos sentidos, quer os mesmos objetos, considerados na sua natureza em-si, embora não os intuamos nela, quer outras coisas possíveis, que não são objetos dos nossos sentidos (enquanto objetos 
pensados simplesmente pelo entendimento) e designamo-los por seres do entendimento (noumena ${ }^{5}$ ) (KANT, 1994, p. 268, B 306).

Kant distingue, assim, fenômenos de númenos. Para ele, como o conhecimento só é possível mediante a ação de estruturas transcendentais inerentes ao sujeito (formas puras da sensibilidade e categorias do entendimento) sobre o material proveniente da afecção sensível, os objetos tais como são em-si mesmos, indiferentes ao sujeito que os conhece, não são acessíveis. O objeto conhecido é, ao mesmo tempo, constituído pelo sujeito. Porém, como uma das exigências à constituição do conhecimento é justamente a afecção sensível, pode-se cogitar a existência de uma coisa em-si, ou seja, de um objeto anterior e indiferente ao modo como o sujeito o conhece. Assim, a coisa em-si tem sempre de poder ser ao menos pensada, embora jamais possa ser conhecida. Para conhecer a coisa em-si, seria necessário apreendêla sem a ação das estruturas subjetivas. Mas, o que não se submete à ação dessas estruturas é justamente o que não é possível conhecer.

Esse é o ponto de vista que a filosofia da época de Hegel assumia, segundo este autor, como necessário para resolver o problema indicado, ou seja, a delimitação e fundamentação do âmbito próprio do conhecimento científico. A partir desse resultado, poderse-ia de antemão saber que toda tentativa de encontrar como objeto do conhecimento a coisa na sua forma pura é ilegítima, pois pretende conhecer algo que está para além das possibilidades do entendimento humano. Para Hegel, entretanto, esse resultado não é em nada uma solução, mas antes um paradoxo. Para ele, o que se mostra aí é antes o fato de que "... usamos um meio que produz imediatamente o contrário de seu fim; ou melhor, o contra-senso está em recorrermos em geral a um meio" (FE, p. 64, § 73). Se o que torna possível o conhecimento é o meio e se a necessidade do meio significa que o conhecimento é algo produzido com influência (seja ela qual for) da atividade subjetiva, então já está afirmado que à coisa mesma, indiferente ao sujeito, não se pode ter acesso. Isso significa que o que no conhecimento alcança-se não é, na verdade, o objeto ao qual ele se refere e que se encontra na base da apreensão cognitiva, na forma de afecção sensível (como concedia Kant). 0 sujeito tem acesso apenas ao que é, de certa forma, produto de seu próprio "aparato cognitivo", que inicia sua ação a partir do múltiplo recebido da sensibilidade. Assim, considerar que o sujeito se vale de uma estrutura cognitiva para conhecer equivale, do ponto de vista hegeliano, à afirmação de que o conhecimento, a rigor, não é possível.

Poder-se-ia, entretanto, buscar a verdade descontando do conhecimento a parte que cabe ao sujeito, para assim permanecer com a coisa como é em-si mesma. Se isso fosse possível, o trabalho crítico teria seu verdadeiro valor no fato de possibilitar ao sujeito a consciência de que nem tudo que ele conhece refere-se à coisa conhecida. Sabendo quais elementos são acréscimos seus, ele poderia retirá-los do resultado e permanecer apenas com o que diz respeito ao objeto. O problema é que, levando em conta a afirmação de que esses

\footnotetext{
${ }^{5} \mathrm{Na}$ sequência do texto, os termos noumena e phaenomena serão traduzidos respectivamente por númeno e fenômeno.
} 
elementos subjetivos são condições à constituição do conhecimento, o desconto da parte que cabe ao sujeito, no resultado final, acaba anulando o próprio conhecimento (FE, p. 64, §73).

Desse modo, para Hegel a filosofia crítica, a partir de seu modo próprio de desenvolver a tentativa de encontrar um fundamento seguro ao saber, acaba levando à conclusão de que ele não é viável. A partir da constatação desse paradoxo fundamental, a análise de Hegel passa, então, a concentrar-se sobre os pressupostos da filosofia crítica. Na verdade, não parece que ele queira simplesmente refutá-la, mas antes radicalizá-la, levá-la às últimas consequências. Para ele, é preciso ir além do criticismo, é preciso “... introduzir uma desconfiança nessa desconfiança..." (FE, p. 64, § 74), investigando aqueles elementos que o próprio ponto de vista crítico aceita acriticamente.

\subsection{Os pressupostos da filosofia crítica}

A filosofia crítica kantiana buscou investigar as condições de possibilidade do conhecimento humano para estabelecer, sobretudo, seus limites. Um dos propósitos mais importantes de Kant era verificar em que medida a metafísica poderia ser ciência. Sua conclusão, como se sabe, foi negativa. Para ele, a metafísica pressupunha o conhecimento de elementos que na verdade, segundo os resultados de sua investigação, estão para além da capacidade humana de conhecer ${ }^{6}$. Isso significa que a filosofia kantiana pôs-se como filosofia crítica por questionar aquilo que até aquele momento era aceito tranquilamente - a possibilidade do intelecto humano ter acesso, em sentido teórico, a realidades extrassensoriais. Hegel, por sua vez, quer aplicar esse procedimento ao próprio Kant. Para ele, a própria crítica kantiana só é possível mediante a aceitação acrítica de certos pressupostos. Assim, em certo sentido, Hegel quer levar adiante o projeto crítico, mediante o qual o que se aceita como pressuposto tem de ser tematizado completamente para que o resultado da investigação a ser empreendida possa ser considerado absolutamente legítimo.

$\mathrm{Na}$ introdução da Fenomenologia, Hegel aponta três pressuposições fundamentais da filosofia crítica: em primeiro lugar, "representações sobre o conhecer como instrumento e meio" (FE, p. 64, § 74). Essa é, evidentemente, uma ideia fundamental do modelo kantiano. A busca das condições de possibilidade do conhecimento pressupõe que o conhecer seja certo instrumento à disposição do sujeito, mediante o qual a atividade cognitiva pode desenvolverse.

O segundo elemento diz respeito à distinção entre o conhecer e o sujeito, ou seja, entre as estruturas transcendentais que condicionam o conhecimento e o sujeito mesmo, que as investiga. Nas palavras de Hegel, trata-se da "diferença entre nós mesmos e esse conhecer" (FE, p. 64, § 74). Isso teria de ser pressuposto na investigação transcendental, pois

\footnotetext{
${ }^{6}$ É claro que com Kant a metafísica não é de modo algum abandonada. Kant na verdade pretende, com a Crítica da razão pura, encontrar também para a metafísica a via segura da ciência. Mas, de acordo com os resultados da Crítica, isso só será possível mediante uma mudança radical de seu conceito. Isso, entretanto, não pode ser tematizado no presente contexto.
} 
o sujeito que analisa as faculdades cognitivas age como se fosse indiferente a elas. Como seria possível verificar quais são as condições de possibilidade do conhecimento humano se, ao supor a existência de tais condições, está-se admitindo que todo conhecimento, e assim inclusive o que resultar desta investigação, está condicionado por essas determinações subjetivas? Ou seja, ter-se-ia de admitir que o sujeito que desenvolve a crítica do conhecimento situa-se num ponto anterior ao ato mesmo de conhecer, pois só assim o resultado poderia ser tomado como legítimo.

Por fim, na sua terceira pressuposição, a filosofia crítica considera ainda verdadeiro um saber separado da coisa a que ele se refere. Como afirma Hegel, pressupõe "que o absoluto esteja de um lado e o conhecer de um outro lado - para si e separado do absoluto - e mesmo assim seja algo real. Pressupõe com isso que o conhecimento, que, enquanto fora do absoluto, está também fora da verdade, seja verdadeiro" (FE, p. 64, § 74). Segundo os resultados da Crítica da razão pura, o sujeito só tem acesso ao âmbito fenomênico. Isso significa que o objeto em-si mesmo, que deve ser pressuposto como base da afeç̧ão sensível, está fora do campo de ação do entendimento. O conhecimento, assim, não expressa o objeto na sua forma pura. Essa restrição, entretanto, não tem papel simplesmente negativo na filosofia crítica. Pelo contrário, ela é justamente a base a partir da qual se pode determinar a legitimidade de um conhecimento. A coisa em-si torna-se o limite externo da atividade cognitiva. Qualquer atividade teórica que quiser apossar-se do que está para além do âmbito fenomênico comete o equívoco de aplicar as categorias do entendimento numa esfera em que isso não é legítimo por definição. O que está para além do conhecer pode apenas ser pensado. Delineiam-se aqui outros usos para a razão, diferente do teórico, em que o fim é o conhecimento. A filosofia crítica, desse modo, propõe como critério para julgar a legitimidade do saber científico a ideia segundo a qual o objeto na sua forma pura não pode ser conhecido. O saber mais adequado, assim, é justamente aquele que não pretende alcançar a coisa no modo como ela é em-si mesma.

A filosofia crítica tem, então, de pressupor que não há incompatibilidade entre o fato de o conhecimento estar condicionado ao modo subjetivo de apreensão e a afirmação de que ele é, justamente quando tomado dessa forma, verdadeiro. Isso se torna ainda mais radical quando se leva em conta o lugar teórico de quem pratica a investigação crítica. Por um lado, é preciso tomar como verdadeiros os resultados da crítica, quer dizer, é necessário admitir que expressam adequadamente a verdade. Mas, por outro, é preciso aceitar também o conteúdo desses resultados, considerando o conhecimento condicionado a certa estrutura subjetiva e, portanto, inadequado à coisa mesma a que ele quer referir-se. É justamente essa dualidade que Hegel vai explorar.

\subsection{A imanência da crítica hegeliana}

É importante observar ainda, antes de tratar dos elementos que dizem respeito diretamente à crítica hegeliana, que a argumentação desenvolvida por Hegel toma por pressuposto a ideia de que "só o absoluto é verdadeiro, ou só o verdadeiro é absoluto" (FE, p. $64, \S 75)$. Ou seja, só o que não é condicionado por nada é verdadeiro, e a verdade só pode 
estar naquilo que "é" por si mesmo. Sendo assim, um saber que não alcança a coisa mesma (o absoluto) não pode ser tomado como verdadeiro. E, da mesma forma, o que é tomado como verdadeiro não pode estar condicionado a certo modo de apreensão. É isso que faz Hegel criticar a radical cisão kantiana entre sujeito cognoscente e coisa em-si. Para ele, na ideia de saber verdadeiro já está incluída a noção de que ele deve expressar completamente a coisa a que ele se refere.

Mas Hegel não pretende resolver a questão apenas com uma afirmação dogmática. Sua pretensão é mostrar que, a partir da própria filosofia kantiana, sua conclusão torna-se inevitável. Ou seja, ele pretende desenvolver uma crítica imanente ao modelo kantiano. E faz isso explicitando o que para ele está implícito na própria argumentação de Kant.

\subsection{0 caráter condicionado da fundamentação crítica do conhecimento}

Como já se mostrou, a filosofia kantiana estabeleceu uma diferença entre o modo com que o sujeito se relaciona com a coisa em-si (simples pensar) do modo com que apreende a verdade cognoscível ou fenômeno (a atividade da sensibilidade e do entendimento). Mas, para Hegel, "no final esse falatório vai acabar numa distinção obscura entre um verdadeiro absoluto e um verdadeiro ordinário; e [vemos também] ${ }^{7}$ que o absoluto, o conhecer, etc., são palavras que pressupõem uma significação; e há que esforçar-se por adquiri-la primeiro" (FE, p. 65 , § 74). Ou seja, para distinguir exatamente qual verdade é possível ao sujeito racional, Kant tem de fazer uso de determinações que desde o início têm de ser consideradas verdadeiras. Ele só pode realizar sua crítica do conhecimento pela via conceitual. Para dizer o que é o conhecimento, ele mesmo tem de fazer uso de um saber já existente. Isso significa que a crítica do conhecimento já é, ela mesma, conhecimento. Não pode legitimamente querer situar-se antes do próprio ato de conhecer. Consequentemente, para ser radicalmente crítica, como pretendia, essa filosofia deveria refletir também sobre seus próprios pressupostos, sobre aquilo que, por eles, acaba tomando como verdadeiro. Ou seja, como afirma Hegel acima, "são palavras que pressupõem uma significação; e há que esforçar-se por adquiri-la primeiro".

Como se pode verificar, o que Hegel faz é mostrar que há uma incompatibilidade entre aquilo que a crítica tem de pressupor e o que ela ao final toma como conhecimento legítimo. Para salvaguardar a possibilidade do conhecimento científico da crítica humeana, Kant teve de afirmar que há uma estrutura racional a priori envolvida necessariamente em todo saber. $O$ ônus dessa determinação é estabelecer uma diferença entre o modo como as coisas são emsi e o modo como elas podem ser conhecidas pelo sujeito. Mas esse na verdade não é apenas um ônus indesejável. Pelo contrário, é a pedra de toque do sistema kantiano, o critério com o qual todas as elaborações da metafísica clássica poderiam ser avaliadas.

O problema, apontado por Hegel, é que todo o edifício crítico depende da, ou está condicionado pela pressuposição de certos conceitos. E esses conceitos só podem servir de

7

Os colchetes são, em todos os momentos, acréscimo do tradutor. 
base legitimadora na medida em que são verdadeiros, ou seja, na medida em que expressam de modo adequado o que ocorre no ato mesmo de conhecer. Assim, ao menos aquele que realiza a crítica tem de estar de posse de um conhecimento incondicionado.

Desse modo, Hegel parte da ideia de que, em Kant, o conhecimento é um instrumento e de que isso implica uma distinção entre a coisa mesma e o que o sujeito pode apreender. Em seguida, sugere que é absurdo tomar um saber como legítimo, considerando-o ao mesmo tempo distinto da coisa a que se refere. Mas este passo está condicionado à ideia de que só o absoluto (saber incondicionado, isto é, que não está submetido a condições) é verdadeiro. Esta tese sem dúvida serviria de crítica a Kant. Mas ela mesma tem ser fundamentada. Hegel tenta fazer isso mostrando que no fundo o próprio Kant acaba assumindo-a sem saber quando tenta tomar a crítica como critério para julgar os demais saberes. Para ele, nesse momento ela mesma, no conjunto de conceitos que a constitui, acaba tendo de pôr-se como um saber absoluto, ou seja, não condicionado. Logo, ela mesma está em desacordo com seus resultados.

\subsection{As exigências hegelianas para uma fundamentação crítica do saber}

Dessa crítica hegeliana é possível deduzir a forma própria desse autor encarar a tarefa que a filosofia crítica pretendia realizar - delimitar completamente o conceito de ciência. Se o próprio ato de determinar o que é o conhecer já implica conhecimento, isto é, só pode realizarse por via conceitual, então ele mesmo tem de tornar-se objeto da crítica. Esse é o ponto de partida de Hegel.

A crítica a Kant faz-se, portanto, mediante a acusação de arbitrariedade na eleição do suporte conceitual da crítica. Mas, com isso, se o próprio Hegel quiser levar a cabo a tarefa de fundamentação da ciência, terá de assumir uma tríplice dificuldade. Em primeiro lugar, não poderá simplesmente escolher outro pressuposto fundamental, pois se fizesse isso acabaria sendo vítima de sua própria crítica. Em segundo lugar, não poderá apenas manter a tarefa crítica como um propósito permanente. Nesse caso, o que fosse tomado como fundamento teria, ele mesmo, de ser fundamentado, levando a uma busca sem fim, impedindo que a tarefa crítica chegasse a um termo. Em terceiro lugar, não poderá simplesmente mostrar que o que é pressuposto na crítica está fundamentado nela mesma. O que é fundamentado não pode servir de base para seu fundamento, justamente porque só na pressuposição de que este já está fundamentado pode ser tomado como legítimo para fundamentar algo. Como, então, estabelecer algo que seja, ao mesmo tempo, base do conhecimento seguro e capaz de resistir à busca por seus pressupostos? Isso só é possível quando esse elemento for capaz de fundamentar a si mesmo. Mas, o que poderia possuir tal capacidade? Somente a verdade, no sentido já expresso por Hegel - o absoluto, o incondicionado.

Pode-se pensar que a ideia de verdade como absoluto, usada por Hegel na introdução da Fenomenologia, tem uma relação estreita com a ideia kantiana de coisa em-si. O que é essencial na ideia de coisa em-si é a incondicionalidade. Os objetos a que o sujeito tem acesso são constituídos pelas estruturas cognitivas a partir do diverso da sensibilidade. Mas a razão é capaz de pensar a coisa livre dessas condições subjetivas. A coisa em-si é, portanto, 
uma ideia que a razão elabora cogitando a existência da coisa indiferente à ação do aparato cognitivo do sujeito. A verdade como absoluto, em Hegel, é justamente isso: a coisa no seu modo próprio de ser, sem a influência de qualquer entidade que Ihe seja estranha. É evidente, por outro lado, que há várias diferenças entre os dois conceitos. Mas todas as diferenças são desdobramentos do fato de Hegel não aceitar a ideia kantiana de que o conhecer é certo instrumento formal, devido aos motivos anteriormente mencionados. Se não é possível sustentar a ideia de que o conhecer é um instrumento, é necessário empenhar-se por alcançar a coisa na sua forma pura. Mas, como se verá mais tarde, essa é apenas a posição inicial de uma consciência que busca ingenuamente a verdade. A procura pela coisa mesma, independente da ação sujeito, mostrará ser antes o caminho da autodescoberta do sujeito.

Só a verdade como absoluto, por ser incondicionada, pode ser fundamento, porque só ela pode resistir à busca por pressupostos. $O$ que é condicionado por algo tem nesse algo a base de sua legitimidade. Consequentemente, a tarefa de fundamentação última não estará completa enquanto todas as condições não estiverem devidamente fundamentadas. Isso, em última instância, só chega a termo quando se alcançar o que não é condicionado por nada. Esse elemento só pode ser o que Kant chamou de coisa em-si e que Hegel chama de absoluto, que no fundo é a ideia de incondicionado, como se mostrou antes.

Desse modo, Hegel demonstra que a tarefa que a crítica do conhecimento pretendia empreender, estabelecer os fundamentos do conhecimento científico, não pode ser realizada como uma atividade prévia ao próprio desenvolvimento da ciência. A ciência é o saber legítimo por excelência. Ora, só um saber cuja legitimidade esteja comprovada pode servir como critério para julgar os demais saberes. Consequentemente, só a ciência pode fornecer o fundamento para si mesma. Os resultados da Crítica da razão pura, por exemplo, só poderiam ser aceitos se os conceitos fundamentais que ela pressupõe estivessem eles mesmos legitimados, ou seja, fossem eles mesmos conceitos da ciência.

Mas, em tudo isso, o que é mais importante é observar a dificuldade metodológica que Hegel pretende tematizar com radicalidade. Desde Platão, a ciência é tomada como conhecimento verdadeiro embasado em razões. Essa prerrogativa é retomada desde o início da modernidade. Descartes, por exemplo, pretende encontrar o ponto em que o saber é indubitável. No fundo, ele quer a razão última a partir da qual se torna possível afirmar que algo é verdadeiro. Em Kant, da mesma forma, o que se busca é uma base indubitável sobre a qual a determinação e a delimitação do âmbito próprio do conhecimento científico poderiam ser desenvolvidas. O problema que sempre surge nesse tipo de investigação é que as razões que se toma para justificar a ciência também precisam ser consideradas científicas, ou seja, também precisam ser fundamentadas. E, no levar a cabo essa tarefa, pode-se acabar tendo de escolher um dos três caminhos falaciosos: o regresso ao infinito, o círculo vicioso ou a parada arbitrária. ${ }^{8}$ Isso significa que há uma constante tensão, intrínseca à própria ciência, entre o saber da verdade e o critério (conceito) de verdade. Ou seja, não basta, à ciência,

\footnotetext{
${ }^{8}$ Esses são os três caminhos definidos pelo conhecido trilema de Münchhauser para toda tentativa de fundamentação da verdade.
} 
tomar-se como conhecimento verdadeiro. Ela tem de ser capaz, de algum modo, de dizer o que é a verdade ou o conhecimento da verdade, pois só assim terá legitimada sua própria atividade.

A acusação de Hegel a Kant, nesse sentido, é dupla. Em primeiro lugar, Kant não fundamenta o aparato conceitual que serve de base para a Crítica da razão pura. Em segundo, os resultados da Crítica não são coerentes com seus pressupostos. Como consequência, a tarefa que a crítica do conhecimento pretendia realizar como um estudo prévio à ciência é transferida por Hegel ao interior do desenvolvimento do próprio saber científico. Isso porque, para determinar fundamentadamente o âmbito próprio da ciência, é preciso considerar que o ponto de vista a partir do qual esse empreendimento é desenvolvido situa-se no interior do saber efetivo da verdade.

Daqui já se pode retirar uma previsão a respeito da obra magna de Hegel, a Ciência da lógica (HEGEL, 1968), embora evidentemente não se possa demonstrar com maior exatidão como isso aparece realmente nesse trabalho. Na medida em que é o lugar da ciência na sua forma própria, ela tem de ser, ao mesmo tempo, uma teoria do método, uma ontologia, uma teologia e uma lógica. É nela que Hegel tem de apresentar e fundamentar a ciência. Por isso, ela é o conhecimento da verdade (ser - ontologia) suprema (Deus - teologia), em que está explícita a legalidade interna do cosmos (leis - lógica) num modo determinado de saber (método - teoria do método). Além disso, o movimento da Lógica tem de ser circular, pois aquilo que tem de ser fundamentado, no caso a ciência, não pode ser diferente do que é o seu fundamento. Assim, depois de encontrar as bases para a ciência, tem-se de constatar que elas também são científicas e, então, que o movimento foi de autofundamentação.

Desse modo, Hegel tenta demonstrar que as pretensões da filosofia crítica só podem ser realizadas pela própria ciência, pois uma teoria que busca fundamentar o saber científico tem de ser ela mesma científica (ser elaborada a partir do ponto de vista do saber verdadeiro). Isso significa que, de certo modo, a teoria do conhecimento tem de ser tematizada somente após o aparecimento da ciência. Ou seja, quando a verdade for encontrada, estar-se-á já no elemento da ciência, a partir do qual será possível também dar razões (fundamentar) ao conhecimento que se tem. Encontrar as bases da ciência, assim, é uma tarefa que só o saber científico pode realizar. Os saberes pré-científicos nada têm a contribuir nisso.

Entretanto, o próprio Hegel, através da Fenomenologia do espírito, propõe-se a estudar esses saberes chamados de pré-científicos. Cabe verificar, então, qual é o propósito e o significado dessa investigação. 


\section{A FENOMENOLOGIA COMO CIÊNCIA DA APARÊNCIA}

O objetivo desta segunda seção é apresentar o propósito da Fenomenologia do espirito: ser uma exposição sistemática do aparecer da ciência à consciência. Esse propósito justifica-se, para Hegel, a partir do duplo conceito de aparência (negativo e positivo), que liga radicalmente o saber aparente com a ciência. Seguindo o espírito da filosofia crítica, Hegel assume a necessidade de expor a ciência não apenas como a verdade acabada, mas também como um processo que se desenvolveu no interior da consciência universal, cuja sistematização serve de introdução àquele que quer compreender o saber científico.

\subsection{A ciência é diferente da aparência}

Na medida em que a fundamentação do saber científico só pode ser dada por ele mesmo, deve-se deixar de lado os conceitos que a filosofia crítica tinha elaborado na tentativa de cumprir essa tarefa como uma atividade anterior à ciência mesma. A razão disso está no fato de que, como esses conceitos são assumidamente anteriores à ciência, valem tanto quanto qualquer opinião, ou seja, não têm fundamento algum. E tudo isso, segundo Hegel, como não tem fundamento, "... desvanece imediatamente quando a ciência entra em cena" (FE, p. 65, § 76).

Hegel entende a ciência como o ponto de vista da verdade, quer dizer, enquanto saber absolutamente verdadeiro. Assim, é o conhecimento da coisa mesma, na sua forma própria. Os saberes não científicos distinguem-se dela porque neles a verdade é apenas aparente, ou seja, é no fundo também sua base, mas não está presente de forma plena. Novamente aqui se poderia fazer uma analogia com a estrutura argumentativa de Kant. $O$ fenômeno é o modo de ser da coisa em-si no entendimento humano, já que ela só está disponível mediante as estruturas a priori do sujeito que conhece. Então, o fenômeno é o aparecer da coisa, o modo como ela se mostra ao sujeito racional. A diferença entre o saber absoluto e o fenomênico, entre o ser e o aparecer, é estabelecida devido à defasagem que há entre o que a coisa é emsi e o modo como ela se apresenta à consciência. Para Kant, o saber do fenômeno é o único legítimo. Então para ele a ciência possui a coisa num modo diferente do que ela é em-si. Mas para Hegel, como já ficou claro, só o saber da coisa mesma corresponde ao conceito de ciência. Na ciência, consequentemente, a coisa tem de estar no modo como é em-si.

Ora, sendo a ciência a posse plena da coisa na sua forma própria e sendo os saberes não científicos aparências da coisa mesma, o surgimento da ciência faz com que todas essas outras formas de compreensão da verdade percam importância. Se os saberes não científicos têm como base a coisa mesma, mas não a expressam de forma plena, quando esta forma é 
alcançada, têm de ser deixados de lado e considerados meros enganos, pois toda verdade passa a ganhar sua expressão adequada num outro elemento, a ciência.

\subsection{A ciência precisa aparecer}

Aparentemente, o próprio conceito de ciência obriga a deixar de lado os saberes que não expressam plenamente a verdade. Entretanto, essa posição não é assumida por Hegel. $\mathrm{E}$ isso porque, como ele mesmo afirma, "a ciência, pelo fato de entrar em cena, é ela mesma uma aparência [fenômeno]: seu entrar em cena não é ainda a ciência realizada e desenvolvida em sua verdade" (FE, p. $65, \S 76$ ). Aqui Hegel salienta o fato de que a ciência, num certo estágio inicial, não está plenamente desenvolvida e, portanto, não é a expressão plena da verdade. Consequentemente, não pode ser distinguida dos saberes científicos, já que a especificidade destes é exatamente a incapacidade de revelar de forma adequada a coisa mesma. E essa compatibilidade ao menos inicial (no momento do "entrar em cena", do aparecer) entre a ciência e o saber não científico é uma das razões que faz com que não se possa descartar este sem maiores considerações.

Noutro sentido, o aparecer da ciência deve ser considerado na sua relação com a consciência para a qual ela se apresenta. Embora a ciência contenha a verdade, quando é apresentada a uma consciência que não atingiu este ponto, ela não é reconhecida como tal. Se a consciência não conhece a verdade, também não pode distinguir qual saber a manifesta. Mais do que isso, a própria verdade, expressa no saber científico, não pode ser compreendida por uma consciência que não se elevou ao ponto de vista do saber verdadeiro.

Em outras palavras, a própria ciência, como todo objeto a ser conhecido, tem de aparecer, tem de ser para outro (para a consciência). Mas, como é que a consciência, que ainda não realizou a tarefa de fazer seu saber corresponder à verdade, percebe a ciência? Esse é o problema agora. Na medida em que a consciência não conhece a verdade, também não pode conhecer a ciência, ou seja, não pode conhecer o saber da verdade. A ciência não pode aparecer imediatamente à consciência na forma que é em-si, pois, para isso, teria de ser percebida a partir de seu próprio elemento, pois só no saber científico é que a verdade pode mostrar-se como é.

Dessa forma, na medida em que o modo com que ela simplesmente aparece é distinto de seu ser real, as formas desse aparecer acabam tendo de ser consideradas saberes não científicos. Por isso, "tanto faz nesse ponto representar-se que a ciência é aparência porque entra em cena ao lado de outro [saber], ou dar o nome de 'aparecer da ciência' a esses outros saberes não-verdadeiros" (FE, p. 65, § 76). Quando se descobre que o que parecia ser a ciência realmente não é, afirma-se que ela simplesmente entrou em cena ao lado desse outro saber. Mas, também se poderia afirmar que esse outro saber foi o modo pelo qual a ciência apareceu, ou seja, foi seu aparecer à consciência. Assim, a própria ciência acaba assumindo a forma de saber não científico, no ato mesmo em que é revelada à consciência. Isso faz com que esse saber não possa ser simplesmente desvinculado da ciência, já que foi graças a ele que ela veio à tona. 


\subsection{O duplo conceito de aparência e o sentido da Fenomenologia}

É importante observar aqui o uso que Hegel faz do conceito de aparência. A princípio, ele está em contraste com a ideia de coisa em-si. A verdade é simplesmente distinta da aparência e deve ser buscada naquilo que não é mero fenômeno. Entretanto, a aparência tem como base uma suposta essência, embora não a expresse adequadamente. Por essa via, Hegel realiza uma aproximação entre ser e aparecer, que é transposta à relação entre ciência e saber não científico. Se a ciência é a expressão adequada da coisa, da qual o saber não científico é apenas uma aparência, então no fundo ambos os saberes referem-se ao mesmo objeto. Além disso, a ciência tem de ser aprendida. Como a ciência não é nada mais que a verdade em sua forma plena, seu aprendizado equivale ao aprendizado da própria verdade. Se a consciência se põe em processo de aprendizado, significa que não conhece a verdade ainda. Inicialmente, portanto, a verdade está para ela na forma de uma aparência, no duplo sentido já indicado: como algo distinto da verdade mesma, mas que é também o modo desta mostrar-se. Portanto, se a ciência assume a forma de aparência enquanto se realiza como saber pleno da verdade e se aparência é o nome que se dá ao saber não científico, então esse saber pode ser tomado também como o aparecer da ciência, ou seja, a forma que a ciência assume no processo pelo qual vai realizar-se plenamente ${ }^{9}$.

É justamente por causa desse duplo conceito de aparência que o estudo dos saberes não científicos, tema próprio da Fenomenologia do espírito, ganha sentido. A ciência por si só deve tratar da verdade e o que é aparência distingue-se dela. Entretanto, a aparência da verdade é também o "aparecer" da verdade, a forma que ela assume para vir à tona. Então, estudar o saber fenomênico, o saber das aparências, é também uma tarefa da ciência, pois esse saber é um modo de ser da verdade. Hegel, assim, reabilita os saberes não científicos, mostrando que qualificá-los como aparências implica não só opô-los à verdade, mas também vinculá-los estreitamente a ela. Os saberes não científicos devem ser estudados, portanto, porque são o "aparecer" da ciência.

Esse vínculo entre o saber aparente e a ciência pode ser mais bem evidenciado levando em conta o processo de aprendizagem da consciência. A ciência é o conhecimento da verdade. Um saber que não expressa completamente seu objeto é só aparentemente verdadeiro. Isso significa que ele mostra de modo distorcido a verdade. Mas, se é através dele que a consciência pode alcançar a verdade mesma, então esse saber é também a própria ciência, em seu aparecer à consciência. Os saberes não científicos são, assim, não apenas diferentes da ciência. São mais bem qualificados quando considerados modos de a ciência configurar-se para uma consciência ainda em processo de aprendizagem.

\footnotetext{
${ }^{9} \mathrm{Hegel}$, assim, concebe o saber não científico como um saber pré-científico. Por ser aparência, o saber não científico é um aparecer - o aparecer da verdade. Ora, a verdade é a própria ciência. Então, o saber não científico é um estágio anterior à ciência, ou seja, é um saber pré-científico.
} 


\subsection{A criticidade como autocrítica da consciência na Fenomenologia}

É importante observar que toda essa argumentação de Hegel só pode ser bem compreendida quando se observa a estratégia de sua construção. Hegel parte da ideia de uma suposta ciência como conhecimento absoluto (incondicionado) e de uma consciência que não a possui. Com esses pressupostos, ele apresenta uma situação ideal: a consciência elevada ao ponto de vista da ciência. A partir dessa situação ideal, ele desenvolve a qualificação da relação entre ciência e saberes não científicos. Em primeiro lugar, há uma diferença entre o que é a verdade para um saber não científico e o que é a verdade para a ciência. Nesse sentido, são opostos. Mas, no processo pelo qual a ciência é apreendida pela consciência, ela não se apresenta na sua forma própria. O saber da consciência quer ser sempre saber da verdade. Mas se a consciência não conhece efetivamente a verdade, esse saber não é científico. Então, o saber não científico é antes o modo como a consciência tomou a verdade, ou seja, o modo como a ciência foi concebida por ela. Dando mais um passo e invertendo a afirmação, sem perder a relação a ser apresentada, Hegel pode dizer então que o saber não científico é o modo como a ciência "apareceu" à consciência. Ou seja, se a consciência tomou o saber não científico como ciência, por considerar seu conteúdo o verdadeiro, e a partir dele apreendeu a verdade, então esse foi o modo como a ciência apresentou-se a ela.

Por outro lado, se a ciência é o conhecimento pleno da verdade, não pode permanecer na forma desse saber aparente. Ela tem de se libertar de sua aparência e ser o que é em-si. Mas, para essa libertação, não basta simplesmente descartar o saber aparente. Observe-se a argumentação hegeliana.

\footnotetext{
Pois sendo esse um saber que não é verdadeiro, a ciência nem pode apenas jogá-lo fora - como visão vulgar das coisas, garantindo ser ela um conhecimento totalmente diverso, para o qual aquele outro saber não é absolutamente nada - nem pode buscar nele o pressentimento de um saber melhor. Por essa asseveração, a ciência descreveria seu ser como sua força; mas o saber não verdadeiro apela também para o fato de que ele é, e assevera que, para ele, a ciência não é nada. Um asseverar seco vale tanto como qualquer outro (FE, p. $65, \S 76$ ).
}

Para ser o que é em-si mesma, a ciência tem de deixar de lado sua aparência, ou seja, os outros saberes, em que a identidade entre o conhecer e seu objeto não está realizada. Porém, como ela ainda não está apresentada na sua forma desenvolvida, já que ainda está "aparecendo", também não é a verdade plena. Assim, ela mesma não tem outro fundamento a seu repúdio aos outros saberes do que uma "asseveração seca"; que, entretanto, também pode ser feita por esses outros saberes com o mesmo nível de legitimidade, já que ambos estão na mesma situação (afastados da verdade). Da mesma forma, a ciência, nesse estágio inicial, não pode dizer estar pressentindo um saber melhor; pois, se ainda não está plenamente constituída, seu pressentimento é condicionado por sua visão ainda incompleta e distorcida da verdade. É preciso, diz Hegel, levar adiante a exposição do saber como ele aparece. E, 
já que esta exposição tem por objeto exclusivamente o saber fenomenal, não se mostra ainda como ciência livre, movendo-se em sua forma peculiar. É possível porém tomá-la, desse ponto de vista, como o caminho da consciência natural que abre passagem rumo ao saber verdadeiro. Ou como o caminho da alma, que percorre a série de suas figuras como estações que Ihe são preestabelecidas por sua natureza, para que se possa purificar rumo ao espírito, e através dessa experiência completa de si mesma alcançar o conhecimento do que ela é em-si mesma (FE, p. 66, § 77).

Na medida em que, na forma como aparece à consciência, a ciência não encontra base para distinguir-se dos demais saberes, é preciso acompanhar o modo como, de seu aparecer, ela se eleva até sua forma plena. Nesse movimento, o que se faz é descobrir de que essência o conhecimento disponível é a aparência. Deixando para trás essa aparência, a consciência vai conhecendo o que é propriamente a ciência e, nisso, ela mesma se eleva a seu ponto de vista. Mas, esse conhecimento do que é a ciência é também, para a consciência, um autodescobrimento. Isso porque o que é descoberto como sendo a aparência da ciência, antes dessa descoberta é, para a consciência, seu próprio conteúdo. Então, para ela, descobrir a essência dessa aparência significa descobrir o que ela mesma é na verdade ou essencialmente. É preciso assim, verificar como, nesse aparecer, a ciência vai deixando para trás suas formas (figuras) incompletas até alcançar o pleno conhecimento do que é em-si mesma. A exposição desse caminho, como se vê, não é a descrição da ciência mesma, na sua forma desenvolvida. É antes a exposição do aparecer da ciência, ou seja, do modo como ela revelou sua forma plena através da passagem pelo seu ser fenomênico. Essa exposição é a própria Fenomenologia do espírito. Nela, segundo Hegel,

a consciência natural vai mostrar-se como sendo apenas conceito de saber, ou saber não real. Mas à medida que se toma imediatamente por saber real, esse caminho tem, para ela, significação negativa: o que é realização do conceito vale para ela antes como perda de si mesma, já que nesse caminho perde sua verdade (FE, p. 66, § 78).

O aparecer da ciência inicia pela consciência natural. Essa é a primeira forma de se buscar a identidade entre o saber e seu objeto. Assim, a consciência natural tem ao menos o conceito de saber verdadeiro. Porém, ao pôr em prova seu saber, a consciência natural vai dar-se conta de que ele é aparente, que realmente é só conceito de saber. Desse modo, a consciência percebe que aquilo que ela tomava como verdade é antes uma simples aparência.

\subsection{A Fenomenologia como introdução à ciência}

Para Hegel, "a série de figuras que a consciência percorre nesse caminho [de autocrítica] é, a bem dizer, a história detalhada da formação para a ciência da própria consciência" (FE, p. 67, § 78). Esse é justamente o conteúdo da Fenomenologia do Espírito. A cada verdade que a consciência assume, uma nova figura é elaborada. A Fenomenologia, assim, deve ser a descrição completa de todas as figuras por que passou a consciência até assumir a forma de ciência. 
Para Hegel, não basta para empreender a ciência, como quiseram os autores modernos anteriores a ele, simplesmente rejeitar a influência da autoridade do pensamento alheio. Fazendo isso ainda não se tem a ciência pronta e desenvolvida na consciência. É necessário passar pelo processo de sua formação ${ }^{10}$. Como se viu, isso se deve ao fato de que só quando conhece plenamente a verdade a consciência pode justificar-se como ciência. Aqui se encontra o elemento que parece dar sentido à elaboração da Fenomenologia do espírito, ou seja, de uma obra em que está apresentado o processo através do qual a consciência eleva-se à ciência. Para ele, como já se deixou claro, não é possível a uma consciência que ainda não conhece a verdade saber o que é o conhecimento da verdade (ciência). Por isso, na medida em que ele mesmo pretendia apresentar numa obra a ciência mesma, teria de supor que seus leitores já tivessem se elevado ao conhecimento da verdade. Sem saber o que é a verdade, não poderiam reconhecê-la. Assim, o propósito da Fenomenologia é servir de introdução à ciência, isto é, possibilitar ao leitor uma espécie de "escada pedagógica" até o conhecimento científico, facilitando sua compreensão.

A Fenomenologia mostra, assim, àquele que quer compreender a ciência, a história detalhada dos modos com que ela se revelou à consciência individual e coletiva, nos diversos períodos históricos. De posse desse instrumento, o próprio indivíduo singular poderá refazer a viagem da consciência em direção à ciência (ou em direção a si mesma), atualizando em-si um processo que é tão longo quanto a história da humanidade. Assim, a Fenomenologia pretende disponibilizar ao sujeito o conjunto de condições sem as quais ele não é capaz de desenvolver e nem mesmo de compreender a ciência.

${ }^{10}$ É interessante perceber que, em Hegel, a consciência não pode ser tomada como uma estrutura formal à parte de qualquer conteúdo concreto. Ou seja, o sentido de uma elaboração cognitiva não é independente de sua verdade. A consciência sempre toma o mundo (verdade) de uma ou de outra forma. Não é possível para ela existir sob uma forma que não seja a de "consciência de algo". Na Enciclopédia das ciências filosóficas, por exemplo, o espírito assume a forma de consciência (que é o objeto da Fenomenologia) quando ocorre a distinção entre o sujeito e seu objeto. Isso significa que, para Hegel, a consciência supõe sempre que seu conteúdo (saber) implique um objeto. 


\section{A ESTRUTURA DA CONSCIÊNCIA COMO BASE DA CRÍTICA}

A tarefa da Fenomenologia, como se disse acima, é servir de introdução à ciência, mostrando ao indivíduo que quer conhecê-la o processo de sua formação. Isso significa que o ponto de vista de seu desenvolvimento é o do simples observador, que apenas acompanha os passos pelos quais a ciência vai revelando-se à consciência; ou melhor, o processo pelo qual a consciência eleva seu ponto de vista desde a visão mais ingênua, ainda completamente envolta em aparências, até o saber científico.

Diante disso, a pergunta que imediatamente surge diz respeito às condições do desenvolvimento desse processo. Isto é, como é possível que a consciência, ainda envolta na aparência, possa, por si mesma, alcançar a verdade? Que elementos podem servir de base a este processo, se a consciência ainda está imersa no saber não científico? Esta terceira seção tem o objetivo de reconstruir as respostas de Hegel para essas questões na Introdução da Fenomenologia do espírito.

\subsection{A negação determinada e a meta interna ao saber}

O primeiro passo para responder a essas questões é perceber que "[...] a apresentação da consciência não verdadeira em sua inverdade não é um movimento puramente negativo" (FE, p. 67 § 79). Ou seja, quando a consciência descobre a inverdade de um saber (resultado negativo), está também afirmando uma nova verdade (resultado positivo). Como o próprio Hegel afirma, o nada é sempre "[...] nada daquilo de que resulta". Por isso, é "[...] um nada determinado e tem um conteúdo" (FE, p. 67, § 79). Observe-se que o lado positivo da descoberta do engano não é a simples asseveração de que um determinado modo de tomar a verdade é inadequado. Se esse fosse o caso, a descoberta do erro apenas impeliria a consciência a procurar um novo caminho. Mas o fato é que a descoberta do erro fornece também o novo caminho. Quer dizer, ela não apenas indica que o ponto de vista anterior é enganoso. O engano posto como engano é o conteúdo de uma nova verdade.

Outro elemento importante é o seguinte. Para Hegel, a consciência se sente impulsionada a levar adiante esse processo de busca da verdade porque "[...] o saber tem sua meta fixada tão necessariamente quanto a série do processo. A meta está ali onde o saber não necessita ir além de si mesmo, onde a si mesmo se encontra, onde o conceito corresponde ao objeto e o objeto ao conceito" (FE, p. 68, § 80). O fim último do saber é corresponder a seu objeto - essa é a sua meta. Por isso, a consciência não pode satisfazer-se com um objetivo menor. A descoberta de que não corresponde ao objeto faz com que o saber 
se mude imediatamente. Assim, não é nenhuma força externa à consciência que a impele a buscar a verdade. Isso está inscrito na própria natureza do saber. Em outras palavras, como é a ânsia pela verdade que obriga a consciência a abandonar todo saber que se mostrar em desacordo com seu objeto, e como essa ânsia é uma representação que a consciência faz a si mesma, a "[...] violência que a consciência sofre - de se lhe estragar toda a satisfação limitada - vem dela mesma" (FE, p. 68, § 80).

A ideia segundo a qual todo saber tem como meta corresponder a seu objeto só pôde ser apresentado por Hegel como decorrência das considerações que fez em relação à filosofia kantiana. De certa forma, esta filosofia apresentara um conceito de saber oposto ao que é pensado por ele. Em Kant, a realização do saber como ciência não implica a correspondência entre ele e seu objeto ${ }^{11}$. Muito pelo contrário, saber legítimo, do ponto de vista teórico, é justamente aquele que não pretende expressar a coisa em-si, mas simplesmente o mundo fenomênico. Se Hegel tivesse aceitado essa como a solução final para o problema do conhecimento, não poderia afirmar que está no conceito de saber a necessidade da correspondência entre ele e seu objeto. Pelo contrário, teria de concluir, junto com Kant, que a legitimidade do saber dá-se justamente quando suas pretensões são limitadas ao âmbito fenomênico. Mas, como se viu antes, Hegel mostra que a pretensão da crítica de Kant, fornecer os fundamentos seguros à ciência, só pode ser alcançada quando o ponto de vista da crítica for o ponto de vista da verdade. Isso significa que a ciência só pode ser conhecimento absoluto, isto é, conhecimento pleno da verdade.

Isso, entretanto, não pode ser tomado como alguma espécie de ponto de partida ao processo fenomenológico. Quer dizer, a ideia de que a meta do saber é corresponder a seu objeto não é um horizonte externo a guiar o desenvolvimento da consciência. Em cada momento do processo, essa meta é reposta pela própria consciência, das formas mais diversas. Nesse sentido, o caso de Kant é apenas mais um, em que a necessidade de o saber corresponder a seu objeto acaba vindo à tona a partir da tentativa de fundamentação da ciência. Assim, a afirmação de Hegel, de que o saber tem uma meta, não deve ser tomada, ao menos segundo as intenções do autor, enquanto estabelecimento de uma estrutura conceitual anterior ao próprio processo responsável por seu desenvolvimento. A meta terá de vir à tona em cada momento, a partir do modo como a própria consciência, envolvida no aparecer da ciência, toma seu saber.

Assim, através dos dois elementos acima, a noção de negação determinada e a constatação de que o saber tem como meta corresponder a seu objeto, Hegel tenta demonstrar que a consciência assume por si própria a tarefa de buscar a verdade e que, no simples ato de descobrir seus erros, já se aproxima dela. Nisto, aliás, apresenta-se o caráter teleológico e, ao mesmo tempo, imanente do desenvolvimento fenomenológico. Quer dizer,

${ }^{11}$ Evidentemente, essa afirmação não pode ser interpretada a partir de um ponto de vista interno à filosofia kantiana. Para Kant, há sim correspondência, se é que se pode chamar assim, entre o conceito e seu objeto. A diferença é que há uma mudança no conceito de objeto. $O$ objeto do conhecimento é o fenômeno. A afirmação em questão, entretanto, toma como objeto do conhecimento aquilo que em Kant foi reduzida a uma ideia da razão - a coisa na sua indiferença ao sujeito cognoscente. 
nesse processo a consciência natural se eleva à ciência, a algo que não é ela mesma; mas esse fim, ao qual ela se dirige, é por ela mesma posto e realizado. Assim, a consciência natural não é a ciência, no sentido de que não realizou a identidade do saber com seu objeto. Mas, por outro lado, é por ela mesma que essa meta é buscada e realizada. Há tanto um horizonte distante do ponto em que a consciência natural está e para o qual ela se dirige (teleologia), quanto o desenvolvimento de algo que lhe é inerente (imanência).

\subsection{0 critério da crítica ao conhecimento}

Mas apenas com esses elementos parece que o exame crítico do saber ainda não é viável. Conforme o próprio Hegel salienta, como se verá a seguir, o procedimento através do qual a consciência examina seu saber para ver se corresponde à verdade padece de um problema elementar: a falta de um padrão de medida. Observe-se sua explicação:

[...] o exame consiste em aplicar ao que é examinado um padrão aceito, para decidir, conforme a igualdade ou desigualdade resultante, se a coisa está correta ou incorreta. A medida em geral, e também a ciência, se for a medida, são tomadas como a essência ou como o em-si. Mas nesse ponto, onde a ciência apenas está surgindo, nem ela nem seja o que for se justifica como a essência ou o em-si. Ora, sem isso, parece que não pode ocorrer nenhum exame (FE, p. 69, § 81).

Se a meta a que a consciência se propõe a cada momento é fazer com que seu saber corresponda ao objeto ao qual se refere, então a tarefa que ela tem de assumir é verificar essa correspondência através de um exame. O exame, por sua vez, não poder ser outra coisa senão a verificação da adequação entre tal saber e a verdade por ele buscada. Mas para isso, como indica Hegel, seria necessário já dispor da verdade. Como verificar se o saber alcançou sua meta se ela não está disponível para a comparação? Ou seja, antes da posse efetiva da verdade parece que também não se dispõe de critério algum para avaliar o saber que pretende ser verdadeiro. Assim, na ausência desse padrão de medida necessário, o próprio exame parece ser impossível.

Para Hegel, essa dificuldade só pode ser superada levando-se em conta os elementos implícitos à própria consciência. Para ele, "[...] a consciência distingue algo de si e ao mesmo tempo se relaciona com ele; ou, exprimindo de outro modo, ele é algo para a consciência. $O$ aspecto determinado desse relacionar-se - ou do ser de algo para a consciência - é o saber" (FE, p. 69, § 82). Ou seja, quando a consciência conhece algo, ao mesmo tempo distingue-se e relaciona-se com ele. A parte que a consciência determina é o saber. "Nós porém distinguimos desse ser para um outro o ser-em-si; o que é relacionado com o saber também se distingue dele e se põe como essente ${ }^{12}$, mesmo fora dessa relação: o lado desse Em-si

\footnotetext{
12 O termo "essente" é utilizado pelo tradutor como correspondente ao alemão "seiende", particípio do verbo "sein" (ser), cujo significado se aproxima de ser imediato, aquilo que "é", o dado.
} 
chama-se verdade" (FE, p. 60, § 82). Além do saber, surge à consciência imediatamente o lado do objeto, da verdade. Isso porque o saber só tem sentido se for saber de algo. Assim, já está posto no conceito de saber que o objeto deve estar presente não só no modo como é para a consciência (que é o próprio saber), mas também na sua forma essencial. Este é o lado da verdade. Desse modo, todo saber já pressupõe uma verdade. Isto é justamente o que possibilita superar o problema da falta de padrão de medida ao exame.

Se todo saber pressupõe uma verdade, a consciência que sabe desde sempre possui um padrão de medida para seu exame. Como Hegel afirma, "[...] a consciência fornece, em-si mesma, sua própria medida; motivo pelo qual a investigação se torna uma comparação de si consigo mesma, já que a distinção que acaba de ser feita incide na consciência" (FE, p. 69, § 84). Ou seja, na medida em que no ato de saber a consciência já distingue dele o objeto em-si mesmo, tanto um como outro estão postos no seu interior. Ora, examinar o saber, para ver se é verdadeiro, é compará-lo com o objeto em-si mesmo. Como também este é representado pela consciência, então a comparação é simplesmente da consciência consigo mesma. Dessa forma, a Fenomenologia pode ser elaborada sem a exigência de previamente apresentar à consciência o objeto assim como ele é antes de ser objeto dela. O lado da verdade, o padrão de medida, está disponível para ela a partir dela mesma.

\subsection{Saber e objeto: as duas faces da mesma moeda}

O objeto está disponível ao saber, para servir-lhe de critério, pois lhe é intrínseco. Então, o próprio exame pode ser tomado de outra forma, como salienta Hegel:

\footnotetext{
Se chamarmos o saber, conceito; e se a essência ou o verdadeiro chamarmos essente ou objeto, então o exame consiste em ver se o conceito corresponde ao objeto. Mas chamando a essência ou o Em-si do objeto, conceito, e ao contrário, entendendo por objeto o conceito enquanto objeto - a saber como é para um Outro - então o exame consiste em ver se o objeto corresponde ao seu conceito (FE, p. 70, § 84).
}

Antes só se podia tomar o exame como o ato de verificar se o saber corresponde ao objeto. Agora, porém, ele também "consiste em ver se o objeto corresponde ao conceito". Esse novo modo de ver a questão foi possível porque se ampliou a compreensão a respeito do objeto (o lado da verdade). Como ele mesmo é tomado pela consciência na sua distinção do saber, pode também ser tratado como conceito, ou melhor, ele é conceito. O saber é o ser para a consciência do objeto. Mas o objeto mesmo é o ser em-si. Na medida em que é a própria consciência que faz essa distinção, ambos são tratados por ela como seus objetos, ou seja, os dois são conceitos. Assim, ao se tomar por objeto o ser como tal, o saber é seu conceito e cabe verificar se este é adequado àquele. Mas, no fundo, fazendo isso se está tomando o saber por objeto e comparando-o a certo padrão de medida - a verdade -, que, por ser também uma representação da consciência, é conceito. Assim, aqui se trata de ver se o objeto, o saber, é adequado ao conceito, à verdade.

O que Hegel está tentando mostrar é que o primeiro ato de a consciência apreender o objeto é sucedido por um segundo, em que saber e objeto são distinguidos. Mediante esse segundo ato, o modo como o objeto é concebido torna-se saber do objeto, do qual tem de ser 
distinguido o objeto como tal. Mas essa distinção e os conceitos envolvidos nela são elaborados pela própria consciência. Isso significa que a representação do ser do objeto enquanto tal, distinto do saber, só pode apresentar-se à consciência como conceito, assim como o saber é conceito. Consequentemente, não só a comparação entre saber e verdade torna-se possível à consciência, já que ambos estão em seu seio, como também tal comparação passa a poder ser considerada tanto como o ato de verificar se o conceito é adequado ao objeto, quanto se o objeto é adequando ao conceito.

Com isso, o ato pelo qual a consciência realiza o mencionado exame pode ser tomado de outra forma. Aparentemente, trata-se apenas da comparação entre saber e objeto. Mas, como ambos são elementos constitutivos da própria consciência, o que se realiza aí é antes a comparação da consciência consigo mesma. Ao tematizar a verdade que está por trás de seu saber, a consciência está tematizando a si mesma. Do mesmo modo, quando ela descobre que a forma como toma a verdade é enganosa e que a verdade mesma está num outro elemento, ocorre não a descoberta de algo, mas antes uma autodescoberta.

\subsection{A unidade entre saber e objeto como resultado da crítica a Kant}

O passo acima descrito é realmente crucial para a elaboração da Fenomenologia do espírito. Se a verdade permanecesse como algo inacessível à consciência, como o próprio Hegel já mostrou, não seria possível conceber um processo de tematização do saber. É interessante observar como essa problemática vem à tona a partir da filosofia de Kant. Este filósofo, como se viu, parte da tese de que o saber teórico tem como base um conjunto de estruturas subjetivas a priori. Consequentemente, a coisa em-si, indiferente a essa estrutura, não poderia ser conhecida. Entretanto, restava um problema. A representação da coisa em-si ainda se fazia presente. Kant não a desprezou simplesmente, afirmando ser uma mera ilusão. A coisa em-si é reabilitada na forma de ideal da razão, uma entidade puramente pensada. A ilusão estaria apenas no ato de tomá-la como objeto do entendimento, confundindo a especificidade das faculdades racionais. Isso significa que a ideia de coisa em-si não terá mais nenhum conteúdo, ou seja, não deverá designar nada a respeito dos seres existentes no mundo, pois este se reduz ao fenômeno. Com isso, Kant evitaria a contradição entre a ideia de que o saber legítimo é aquele que se atém aos fenômenos e a ideia de que a verdade é a coisa no seu modo próprio de ser. A primeira representação diria respeito ao modo como ocorre o conhecer, cuja base seria a ideia de que só na pressuposição de uma estrutura transcendental, que portanto reduziria o mundo conhecido a fenômeno, poder-se-ia conceber a objetividade (necessidade e universalidade) do saber. A segunda representação, por sua vez, seria fruto do simples pensar, em que se cogitaria a necessidade de uma coisa em-si, anterior ao ato cognitivo, como base da afecção sensível.

Se este isolamento entre as duas esferas, a dos fenômenos e a dos seres puramente pensados, fosse mantido, a argumentação hegeliana apresentada acima não seria possível. A consciência disporia apenas do saber do objeto. A representação do objeto como tal, que para Hegel deve servir de padrão de medida para o exame do saber, deveria ser tratada como algo de natureza absolutamente diversa, de modo a não fornecer consideração alguma sobre o 
mundo conhecido. Hegel ataca justamente esta separação, que em Kant aparece na forma de distinção entre fenômeno e númeno. Seu argumento, como já ficou explícito na primeira parte deste capítulo, é que essa distinção, assim como todas as demais considerações da filosofia crítica, dependem de conceitos a respeito do que seja sujeito, objeto, saber, absoluto, etc. Esses conceitos, por sua vez, só são legítimos na medida em que descrevem adequadamente a realidade designada. Portanto, a ideia da verdade como expressão adequada da coisa, isto é, como saber absoluto, acaba voltando pela porta dos fundos. Embora ela seja tratada no interior da teoria kantiana como uma representação de cunho prático e não teórico, ela está no fundo, pensa Hegel, na base de sua filosofia na forma de um pressuposto necessário. Embora diga que a coisa mesma não pode ser conhecida, Kant tem de pressupor que suas ideias a respeito do mundo a ser conhecido, do sujeito que os conhece e do que seja o próprio conhecer estão corretas, ou seja, são expressões adequadas dos objetos por elas referidos. A distinção kantiana entre fenômenos e númenos, portanto, segundo Hegel, é uma afirmação estéril, pois tem na sua base justamente o oposto - a perfeita adequação entre o saber e seu objeto.

É interessante perceber que, a partir dessas considerações, a crítica hegeliana a Kant assume o mesmo aspecto daquilo que Hegel apresenta como sendo o exame que a consciência realiza sobre seu saber. Ou seja, o que Hegel faz é uma comparação entre o que é expresso no saber elaborado por Kant, o fato de só o fenômeno ser acessível, etc., e o que é pressuposto como verdade por esse saber, a necessidade de que aí esteja a expressão completa do que seja o saber, o objeto, o sujeito, etc. É da inadequação desses elementos que a crítica hegeliana ganha sua força.

\subsection{A descoberta do engano como construção da verdade}

A Fenomenologia do espírito, na medida em que toma por objeto os saberes não científicos, descreve justamente essa situação em que a correspondência entre saber e objeto não é alcançada. Observa-se a argumentação de Hegel.

Caso os dois momentos [o saber e o objeto] não se correspondam nessa comparação, parece que a consciência deva então mudar o seu saber para adequá-lo ao objeto. Porém, na mudança do saber, de fato se muda também para ela o objeto, pois o saber presente era essencialmente um saber do objeto; junto com o saber, o objeto se torna também um outro, pois pertencia essencialmente a esse saber (FE, p. 71, § 85).

Como se afirmou antes, o objeto é determinado a partir do saber. Quando a consciência examina seu saber, compara-o com o objeto. Não havendo concordância, fica evidente a falsidade do saber e a necessidade de encontrar outra forma para expressar a verdade. Mas, se o objeto era determinado a partir do saber, com o sucumbir deste também aquele desvanece.

É importante observar a estratégia utilizada por Hegel. Quando se trata da relação saber-objeto, normalmente toma-se como ponto de partida o objeto e considera-se o saber como sua representação mais ou menos adequada. É como em Kant, em que o aparato cognitivo tem à disposição um conjunto de afecções a partir das quais elabora conceitos e 
juízos. Entretanto, o próprio Kant percebeu que com isso o objeto mesmo não poderia estar disponivel ao sujeito. Então, a ideia de um objeto na sua forma pura não poderia ser decorrente de uma afecção e da consequente atividade do entendimento. Deveria ser posta a partir do próprio sujeito, na forma de uma ideia pura. O que Hegel faz é mostrar que esse artifício não é legítimo, na medida em que é inerente ao saber a necessidade de pressupor um objeto. Os próprios conceitos, os quais servem de base para a teoria que elabora a separação entre fenômenos e númenos, têm de ser a expressão correta da realidade que descrevem e, portanto, contradizem o que pretendiam demonstrar. Assim, para Hegel saber e objeto estão intimamente vinculados. Sempre que há um saber, há também uma ideia do que seja o objeto a que ele se refere. E cada saber pressupõe uma noção específica de objetividade. Com isso, sempre que a inverdade de um saber é demonstrada, também o objeto a que ele se referia desvanece, pois era conhecido a partir do modo como estava representado no saber.

Esse, entretanto, é apenas o resultado negativo a que a consciência chega a partir do exame de seu objeto. Como já se afirmou no início desta seção, para Hegel em toda conclusão negativa há também algo de positivo. A descoberta da falsidade é também a elaboração de um novo saber. Assim, ao concluir que o saber que possuía é falso, a consciência desenvolve também um novo saber.

À primeira vista, este novo saber é apenas uma nova e mais adequada forma de a consciência apropriar-se do objeto. Quer dizer, a consciência tomou como padrão de medida o objeto e verificou até que ponto o saber lhe era adequado. Mediante a descoberta de que essa adequação não ocorria, a consciência tomou o saber como falso. É de se esperar, por isso, que o novo saber surja simplesmente para expressar de modo mais adequado a verdade que estava posta desde o início. Ora, o saber foi rejeitado porque não expressava de modo correto o objeto. Logo, o novo saber deveria simplesmente manifestar o objeto de uma forma mais adequada, o que significa que o padrão de medida, o que é tomado como verdade, continuaria o mesmo. Entretanto, a verdade, o padrão de medida, foi alcançada a partir do saber anterior, agora tomado como falso. Isso significa que a verdade estava disponível ao sujeito através do saber que ele tinha dela. Consequentemente, quando esse saber é refutado, junto com ele também desvanece a verdade assim como era considerada anteriormente. A verdade, agora, estará disponível conforme o novo saber que surgiu. Para Hegel, isso significa que "o exame não é só um exame do saber, mas também de seu padrão de medida" (FE, p. 71, § 85). Como o saber mostrou ser falso, e com isso fez desvanecer a verdade da qual era a expressão, e como essa verdade era o padrão de medida, o exame não só refuta o saber mas também a verdade que está pressuposta junto com ele. $O$ surgimento de um novo saber implica também uma nova forma de conceber a verdade.

\subsection{0 conceito de experiência}

Para Hegel, todo esse processo deve ser chamado de experiência. Ele tenta justificar isso apresentando a seguinte argumentação:

A consciência sabe algo: esse objeto é a essência ou o Em-si. Mas é também o Em-si para a consciência; com isso entra em cena a ambigüidade desse verdadeiro. Vemos 
que a consciência tem agora dois objetos: um, o primeiro Em-si; o segundo, o serpara-ela desse Em-si. Esse último parece, de início, apenas a reflexão da consciência sobre si mesma: uma representação não de um objeto, mas apenas de seu saber do primeiro objeto. Só que, como foi antes mostrado, o primeiro objeto se altera ali para a consciência; deixa de ser o Em-si e se torna para ela um objeto tal, que só para a consciência é o Em-si. Mas, sendo assim, o ser-para-ela desse Em-si é o verdadeiro; o que significa, porém, que ele é a essência ou é seu objeto. Esse novo objeto contém o aniquilamento [nadidade] do primeiro; é a experiência feita sobre ele (FE, p. $71, \S 86$ ).

O aspecto principal que Hegel quer salientar aqui é o modo como ocorre a passagem do primeiro ao segundo objeto, pois é justamente nisso que, pensa ele, ocorre o que se chama de experiência. $O$ primeiro objeto é simplesmente o que é tomado pelo saber como a verdade a ser expressa. Assim, o primeiro objeto deve ser o em-si, ou seja, deve ser aquilo que é por si mesmo e que está no saber de forma pura. Entretanto, esse em-si está disponível à consciência a partir do saber que ela tem dele. Isso significa que ele é um em-si apenas para a consciência. À primeira vista, essa consideração não tem nada a ver com o objeto mesmo. É apenas o resultado do ato de a consciência revisar o conhecimento disponível. Entretanto, este ato reflexivo implica um novo saber. O simples saber do objeto é substituído pelo saber que sabe que o objeto está disponível apenas na forma como é representado pelo saber. Ou seja, o conteúdo do novo saber não é mais o objeto como um em-si, mas o objeto como algo que é em-si só para a consciência. Assim, o que é posto como verdade agora é o objeto como um em-si para a consciência.

Mas a nova verdade a rigor não é nada mais do que a anterior. Trata-se do mesmo objeto. A diferença é que agora o saber expressa de modo mais adequado o que já estava presente antes. $O$ primeiro saber já era o conhecimento do objeto como um em-si para a consciência. No fundo, esse era o objeto que o saber pressupunha. Entretanto, no saber mesmo ele aparecia como algo em-si, como a coisa independente da consciência. Mediante a descoberta de que esse em-si é apenas para a consciência, o saber muda-se e com ele a verdade passa a ser apresentada de forma mais adequada. Então, tanto se pode dizer que se trata do mesmo objeto, pois o segundo saber apenas expressa o mesmo de modo mais pleno; quanto se pode afirmar que são objetos diferentes, pois o que é tomado como verdade no segundo saber difere do que era no primeiro.

A diferença entre os objetos de um e de outro saber mostra que houve aprendizado, quer dizer, que a consciência apossou-se de algo que não possuía antes. $O$ vínculo entre eles, por sua vez, revela o fato de que esse aprendizado não foi o simples apossar-se de algo totalmente novo e externo ao que a consciência já dispunha. Isso é facilmente verificado a partir da simples observação do conteúdo que constitui o segundo objeto. Ora, ele nada mais é do que a negação do primeiro objeto. Ele é um em-si, como o primeiro, mas um em-si que só é para a consciência. Isto é o que Hegel chama de experiência: o processo pelo qual a consciência, a partir de seu saber aparente, vai descobrindo a verdade que está por trás dessa aparência.

O conceito de experiência é importantíssimo para o sentido que Hegel concede à Fenomenologia do espírito. Por isso, o próprio Hegel o explora de modo mais demorado, cogitando o fato de que a princípio não parece que esse movimento da passagem de um 
objeto a outro mereça ser chamado de experiência. Isso porque, "[...] parece que nós fazemos a experiência da inverdade de nosso primeiro conceito, em um outro objeto, que encontramos de modo um tanto casual e extrínseco; e dessa forma só nos toca o puro aprender do que é em-si e para si" (FE, p. 72, § 87). A descoberta de que o primeiro saber é falso ocorre pela comparação deste com o objeto correspondente. O que acontece aí é que o objeto comportase de modo diferente daquele que estava previsto no saber. Com isso, a consciência descobre que o objeto mesmo é outro, não aquele que ela imaginava ser o real a partir de seu saber anterior. E, para ela, essa descoberta ocorre simplesmente porque o objeto verdadeiro revelou-se a ela. A verdade, assim, teria vindo à tona na forma de um aparecimento do objeto à consciência. $O$ objeto, na forma como era conhecido anteriormente, agora não passa de uma mera ilusão a ser abandonada em vista da verdade. Sob este ponto de vista, a passagem de um objeto a outro não é uma experiência, mas antes um simples aprender, como afirma Hegel. Para a consciência, a verdade simplesmente mostrou-se, forçando-a a abandonar o ponto de vista anterior.

Isso vai definir mais precisamente o caráter da própria Fenomenologia do espírito. Por um lado, para a consciência envolvida no processo de aprendizagem, a verdade simplesmente se revela. Para ela, assim, a aprendizagem é casual, baseada no simples ato de deparar-se com a verdade. Mas, por outro lado, a verdade que surge pode também ser considerada como o resultado do ato de a consciência tematizar seu saber. Aqui a verdade é resultado da experiência da consciência sobre seu objeto. Neste segundo ponto de vista, o objeto que surge como nova verdade não é simplesmente apanhado na sua imediatez. Ele é constituído a partir da tematização que a consciência faz de seu saber. Com isso, a aprendizagem pode ser exposta não como algo casual, mas antes como o desenvolvimento necessário dos elementos intrínsecos à consciência. Assim, através da descoberta desse fio de necessidade a ligar as diversas experiências da consciência, a exposição do processo de aprendizagem ganha o status de ciência.

\subsection{Os dois pontos de vista da Fenomenologia do espírito}

Contudo, como enfatiza Hegel, "essa consideração da Coisa é uma achega de nossa parte, por meio da qual a série das experiências se eleva a um processo científico; mas, para a consciência que examinamos, essa consideração não tem lugar" (FE, p. 72, § 87). Em outras palavras, há uma diferença entre o ponto de vista a partir do qual a Fenomenologia é elabora e o ponto de vista da consciência que aprende. Ora, a Fenomenologia, como uma obra filosófica, tem de expor seu objeto na sua forma própria. No caso, o objeto é o processo de aprendizagem da consciência. Ora, se a consciência está aprendendo, então é saliente o fato de que ainda não conhece a verdade. Por isso, de antemão já se pode saber que seu modo de ver a aprendizagem a ser exposta não é o adequado. Essa deficiência no ponto de vista da consciência fenomênica revela-se no fato de ela não ser capaz de perceber que o objeto que aprende na verdade é o desenvolvimento de seu ponto de vista anterior. Isso, aliás, é também o que faz com que ela veja seu aprender como algo casual. Mas, para quem já conhece a verdade, quer dizer, para quem já chegou ao final do processo de aprendizagem, o 
que ocorre aí é nítido. A consciência aprende a partir da experiência do engano. A verdade é antes o desenvolvimento do saber aparente. Com isso, a própria aprendizagem acaba tendo de ser considerada de modo diferente. Não pode mais ser apenas um apossar-se casual da coisa. Ela ganha o caráter de desenvolvimento necessário. Por esse acréscimo por parte do observador, que é simplesmente a descoberta de algo que está implícito, a exposição torna-se ciência. Por isso, a Fenomenologia pode ser chamada de "[...] ciência da experiência da

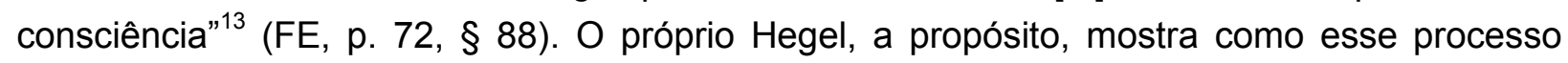
ocorre:

\begin{abstract}
É assim que o processo aqui se desenvolve: quando o que se apresentava primeiro à consciência como objeto, para ela se rebaixa a saber do objeto - e o Em-si se torna um ser-para-a-consciência do Em-si, - esse é o novo objeto, e com ele surge também uma nova figura da consciência, para a qual a essência é algo outro do que era para a figura precedente. É a essa situação que conduz a série completa das figuras da consciência em sua necessidade. Só essa necessidade mesma - ou gênese do novo objeto - se apresenta à consciência sem que ela saiba como lhe acontece. Para nós, é como se isso Ihe transcorresse por trás das costas. Portanto, no movimento da consciência ocorre um momento do ser-em-si ou do ser-para-nós, que não se apresenta à consciência, pois ela mesma está compreendida na experiência. Mas o conteúdo do que para nós vem surgindo é para a consciência: nós compreendemos apenas seu [aspecto] formal, ou seu surgir puro. Para ela, o que surge só é como objeto; para nós, é igualmente como movimento e vir-a-ser (FE, p. 72, § 87).
\end{abstract}

Em primeiro lugar, é importante observar o uso do termo figura. Cada modo de a consciência tomar seu objeto e a si mesma, enquanto conhecedora da verdade, é uma figura, ou seja, é um modo de a consciência ser. Quando a consciência toma seu objeto como um em-si, está-se portando perante ele e perante si mesma de uma determinada forma, constituindo uma figura. Isso significa que, quando a consciência passa a tomar seu objeto como um em-si que é só para ela, também elabora uma nova figura, ou seja, passa a comportar-se em relação à verdade e a si mesma de outra e determinada forma. Por isso, o processo de aprendizagem da consciência, isto é, o processo pelo qual ela busca a verdade a partir das aparências de que dispõe, que também pode ser chamado de experiência, é ainda a exposição completa de todas as suas figuras.

O outro aspecto a ser mencionado relaciona-se ao que já se mostrou antes. Porque está envolvida no saber aparente, a consciência não é capaz de ver seu objeto de modo adequado. Por isso, não percebe que ele é fruto de sua experiência com o saber anterior. Ou seja, para ela, a verdade é um objeto que se apresenta e não a própria experiência da descoberta de seus enganos. Isso significa que a Fenomenologia terá de apresentar algo que não está disponível à consciência mesma. Embora este elemento seja no fundo o motor do processo de aprendizagem, só quem já o ultrapassou pode percebê-lo. Por isso, a elaboração da Fenomenologia só é possível a quem já chegou ao final do processo e conhece o que

${ }^{13}$ Este, aliás, foi o primeiro título que Hegel deu a sua obra. 


\section{Ediovani Antônio Gaboardi}

ocorre "por trás das costas" da consciência que apreende. Este ponto de vista último é o que Hegel chama de saber absoluto. O que há de essencial neste estágio do saber é o seguinte.

Aqui [no Saber Absoluto] a aparência se torna igual à essência, de modo que sua exposição coincide exatamente com esse ponto da ciência autêntica do espírito. $E$, finalmente, ao apreender sua verdadeira essência, a consciência mesma designará a natureza do próprio saber absoluto (FE, p. 73, § 89).

O saber absoluto nada mais é do que a realização daquilo que foi posto como meta do saber: a expressão adequada da coisa mesma. Esse saber, assim, não é mais uma mera aparência. Ele é a própria essência.

A partir da posse da verdade, o saber da consciência é a própria ciência. Por isso, a exposição do saber absoluto é a exposição do saber científico. Mas a ciência já estava presente no saber da consciência natural. Não na sua forma própria, é verdade, mas ao menos como aparência. Ora, a aparência só pode ser caracterizada adequadamente quando se sabe de que ela é aparência, ou seja, qual é a essência que está aparecendo nela. No saber absoluto, a consciência possui a verdade, então possui o elemento que estava na base do aparecer fenomenológico. Assim, agora é possível também expor de modo adequado o aparecer da ciência à consciência, que é o objeto próprio da Fenomenologia do espírito.

\subsection{Conclusão: a Fenomenologia como desenvolvimento da crítica}

Como se pode ver, a Fenomenologia surge a partir de algumas ideias básicas de Hegel a respeito do projeto de fundamentação da ciência. A fundamentação determina o âmbito legítimo da ciência. Mas, se a ciência é o conhecimento verdadeiro, então aquilo que determina seu âmbito legítimo também precisa ser um conhecimento científico. Pois, se o fundamento não é científico, então não é verdadeiro e, se não é verdadeiro, não serve para fundamentar coisa alguma. A conclusão desse raciocínio é que a tarefa crítica de fundamentação da ciência não pode estar completa antes de a própria ciência, como conhecimento pleno da verdade, ter sido realizada.

Esta constatação possibilita a Hegel justificar a ideia de que o saber tem como meta corresponder a seu objeto. A filosofia kantiana tinha encontrado uma forma de evitar a radicalidade dessa conclusão convertendo o objeto do saber em fenômeno. O objeto mesmo, a coisa em-si, deveria ser tratada como uma ideia da razão e não como um conceito referente ao mundo conhecido. Assim, os conceitos do entendimento teriam como referência objetos, mas apenas do mundo fenomênico. Hegel tenta mostrar que esse artifício argumentativo no fundo não resolve problema algum, pois os conceitos que the servem de base ainda precisam corresponder plenamente aos objetos a que se referem. Está aqui posta, portanto, uma das ideias fundamentais que guiam o processo exposto pela Fenomenologia do espírito: a ideia de que o saber tem uma meta, segundo a qual ele deve corresponder a seu objeto. É claro, entretanto, que não se trata de uma espécie de princípio a partir do qual o processo pode ser simplesmente deduzido. Cada figura da consciência repõe por si mesma essa meta, a partir dos elementos constitutivos de sua própria experiência. 
Aqui está a fonte de outro elemento essencial à Fenomenologia do espírito. Trata-se da afirmação de que o saber dispõe de um padrão de medida mediante o qual sua legitimidade pode ser verificada. A filosofia kantiana, de certa forma, tinha elaborado um padrão de medida. Diferente, é claro, do que Hegel tem em mente, pois esse padrão de medida era, naquela filosofia, as condições a priori do sujeito. Saber legítimo era aquele que não pretendia referir-se a objetos que estivessem além das possibilidades cognitivas do sujeito racional. Por esse ponto de vista, Hegel, trata de demonstrar que a filosofia kantiana no fundo afirma o oposto de que pretende afirmar. A distinção entre fenômenos e númenos não acaba com a necessidade de o saber corresponder ao que o objeto é em-si. Muito pelo contrário, a pressupõe. Os conceitos que a legitimam tem de ser a expressão adequada das realidades a que se referem. E Hegel vai além. Toma o saber elaborado por Kant como primeiro objeto a ser examinado, aos moldes das experiências a serem expostas na própria Fenomenologia. Saber verdadeiro, segundo os resultados da Crítica de Kant, é o que se refere ao fenômeno. Esta é uma caracterização da verdade. Entretanto, esse mesmo saber, que diz o que é a verdade, deve ser a expressão adequada da realidade que descreve. Isso significa que há uma contradição entre o que ele afirma ser verdadeiro, o fenômeno, e o que ele mesmo toma por verdadeiro, o objeto como tal.

Outra ideia importante, conforme se apresentou anteriormente, é a de que a negação de um saber é também a elaboração de um novo e, consequentemente, de uma nova posição da consciência a respeito da objetividade e de si mesma. Isso também poderia ser relacionado com a crítica de Hegel a Kant. A afirmação kantiana de que o sujeito só tem acesso ao mundo fenomênico é, a princípio, uma conclusão negativa para a tentativa de conhecer os objetos como são em-si. Entretanto, ela implica também certa caracterização do mundo a ser conhecido e do sujeito que o conhece. Coisa em-si, fenômeno, sujeito, etc., são todos conceitos que precisam ser verdadeiros para que a crítica do conhecimento possa ser válida. A conclusão negativa a respeito da possibilidade de conhecer a coisa em-si, portanto, é ao mesmo tempo a afirmação do que seja o objeto a ser conhecido, o sujeito que o conhece e o próprio ato de conhecer.

Como se pode observar, há na argumentação de Hegel três elementos importantes do ponto de vista metodológico: a meta imposta pela própria consciência de o saber corresponder a seu objeto, a verdade como um elemento imanente à consciência servindo de padrão de medida para seu saber e a ideia de que a negação do saber não tem significado meramente negativo. Esses elementos estão presentes na crítica de Hegel a Kant e também vão ser importantes no desenvolvimento do processo de aprendizagem da consciência exposto pela Fenomenologia do espírito mesma.

É importante observar que Hegel não partiu desses elementos na introdução da Fenomenologia para depois proceder à crítica a Kant, por exemplo. Pelo contrário, eles são apresentados após essa crítica. A crítica a Kant, como já se sugeriu, é análoga ao processo exposto na própria Fenomenologia. Isso significa que, afirmando mais uma vez, os elementos citados não devem ser tomados como bases legitimadoras da argumentação, externas ao próprio desenvolvimento da consciência que é apresentado. Mantém-se aqui o ponto de vista 
do simples observar. A consciência mesma representa para si estes elementos a partir do modo como toma seu objeto e a si mesma.

A Fenomenologia é, assim, a exposição completa de uma espécie de crítica do saber elaborada pela própria consciência que o possui. Essa crítica, entretanto, não segue um padrão fixo. Isso porque seus elementos essenciais, o saber e o objeto que the serve de padrão de medida, vão assumir as características mais variadas, de acordo com cada figura da consciência. Mas há algo de ainda mais importante. Como se mostrou antes, devido ao fato de a verdade estar vinculada ao saber e de este ser fruto da experiência que a consciência realiza ao tematizar seu modo de ver a verdade e a si mesma, o aprendizado é antes o desenvolvimento dos elementos que estão implícitos naquilo que é tomado como verdade. Em outras palavras, a cada passo a consciência descobre que o problema não está no fato de seu saber não ser plenamente adequado ao objeto que quer referir-se. Pelo contrário, ela se dá conta que o problema está naquilo que é pressuposto como a verdade à qual o saber deveria adequar-se. Ela percebe que no fundo esse objeto é apenas fruto de seu modo precário de conceber a verdade e a si mesma. E, na medida em que o engano é descoberto, a própria verdade vai aparecendo à consciência. 


\section{CAPÍTULO II}

\section{A AUTOCRÍTICA DA CERTEZA SENSÍVEL}




\section{A ESTRUTURA DA CERTEZA SENSÍVEL}

Neste segundo capítulo, será apresentada a primeira figura da Fenomenologia do espírito: a certeza sensível. Esta exposição está dividida em duas seções, a primeira abordando a estrutura e a segunda as experiências da certeza sensível. O fio condutor desta reconstrução é a tentativa de evidenciar que os elementos e processos inerentes à figura da certeza sensivel são expressões do modelo de autocrítica apresentado por Hegel como resultado de sua crítica a Kant, como foi discutido no primeiro capítulo.

Nesta primeira seção do capítulo, serão descritas as características da certeza sensível; marcadamente a concepção segundo a qual seu saber é a expressão imediata da realidade que se dá em evidência na sua singularidade.

\subsection{0 problema do começo da Fenomenologia do espírito}

O título do primeiro capítulo da Fenomenologia do espírito é "a certeza sensível ou: o Isto ou o Visar" (FE, p. 74). A pergunta que logo surge é por que a Fenomenologia tem de começar justamente por este ponto. A resposta a esta pergunta pode ser extraída das próprias considerações iniciais de Hegel e da ideia geral que move a Fenomenologia e revela aspectos interessantes sobre a obra. No primeiro parágrafo do capítulo, o autor afirma o seguinte.

\footnotetext{
O saber que, de início ou imediatamente, é nosso objeto, não pode ser nenhum outro senão o saber que é também imediato: - saber do imediato ou do essente. Devemos proceder também de forma imediata ou receptiva, nada mudando assim na maneira como ele [o saber imediato] se oferece, e afastando de nosso apreender o conceituar (FE, p. 74, § 90).
}

É interessante observar que Hegel faz aqui um jogo com a palavra imediatez. Em primeiro lugar, imediata é a relação entre o início da Fenomenologia e o seu primeiro objeto. Em segundo, o saber da certeza sensível é imediato. Em terceiro, o objeto desse saber também é imediato. E, por fim, a própria relação entre aquele que observa a certeza sensível e ela mesma deve ser imediata. A primeira e a última considerações dizem respeito aos pressupostos necessários à elaboração da Fenomenologia. A segunda e a terceira referem-se ao próprio objeto a ser exposto.

Na última consideração, Hegel apresenta a ideia, já mencionada anteriormente, de que a Fenomenologia apresenta o desenvolvimento autônomo da consciência. Por isso é necessário evitar o "conceituar" e proceder de modo "receptivo". É preciso partir do modo como o saber está presente na certeza sensível e simplesmente acompanhar seu $41^{\circ}$ 
desenvolvimento, evitando inserir aí elementos estranhos ao que está à disposição da consciência mesma.

Na primeira consideração, por sua vez, Hegel afirma que a figura inicial da consciência, a ser exposta na Fenomenologia, não pode ser outra senão a certeza sensível. Ora, pelo que se disse acima, não é próprio à Fenomenologia tematizar um objeto determinado a partir da aplicação de certo método sobre ele. O papel da Fenomenologia é apenas expor o processo pelo qual a consciência conhece a verdade. Então, a rigor a Fenomenologia não deve utilizar método algum, se por método entende-se certo instrumental a ser aplicado sobre uma coisa qualquer. O papel do observador é simplesmente seguir o desenrolar da própria coisa a ser exposta. Isso significa que o início da Fenomenologia, a rigor, é determinado pelo aparecimento de seu objeto - a consciência no processo de seu autoexame. Mas o problema é que a certeza sensível não tem condições de considerar a si mesma a primeira forma de a consciência tomar a verdade. Ela não se considera a primeira, mas antes a única. Ela não pode saber que aquilo que toma como verdade é apenas uma aparência, cujo desenvolvimento completo fará com que ela modifique radicalmente seu ponto de vista. Com isso, o que fica evidenciado é que o ato de tomar a certeza sensível como primeira figura da consciência só pode ser realizado por aquele que conhece o processo em que ela está se inserindo. $E$, isso só é possível a quem já se elevou a um ponto de vista superior. Em outras palavras, só na posse da verdade pode-se saber a diferença entre ela e sua aparência. Então, o saber sensível só é um aparecer da verdade para quem conhece a verdade mesma. E, como a verdade só surge na medida em que é alcançada por trás de seu aparecer, só quem ultrapassou este estágio inicial pode saber qual é o estágio inicial, ou seja, o estágio da mera aparência. A conclusão disso é que, no fundo, o início da Fenomenologia só pode ser determinado por quem chegou ao seu final.

$\mathrm{Na}$ segunda consideração, Hegel caracteriza o saber da certeza sensível. Ele é imediato, ou seja, se relaciona a seu objeto sem nenhum interposto. Toma o objeto na forma como é. Isso significa, como indica também a terceira consideração mencionada, que inclusive seu objeto é imediato, ou seja, está disponível à consciência na sua forma pura. Esse passo, aliás, é extremamente interessante. A primeira caracterização parece dizer respeito apenas ao saber. Contudo, ela implica certa forma de conceber a verdade. Ou melhor, ela supõe que a verdade seja de uma certa forma determinada. Imediato é o saber que simplesmente capta seu objeto, isto é, que tem como conteúdo apenas o ser desse objeto. Isso significa que o próprio objeto do saber é imediato, isto é, está constituído sem a interferência de qualquer elemento estranho a ele. Em outras palavras, se o saber é a posse imediata do objeto referido, deve-se supor que o ser que é sabido "é" sem influência alguma da consciência. Passa-se, portanto, de uma consideração que diz respeito simplesmente ao saber, para outra que diz respeito à própria coisa "sabida".

\subsection{Imediatez: riqueza e pobreza da certeza sensível}

Essa ideia de imediatez é extremamente importante e por isso precisa ser mais bem explorada, seguindo os passos do próprio Hegel. Para ele, o saber da certeza sensível está 
imerso num paradoxo. Por um lado, aparece "como o mais rico conhecimento, e até como um conhecimento de riqueza infinita, para o qual é impossível achar limite". Por outro lado, "essa certeza se faz passar a si mesma pela verdade mais abstrata e mais pobre. Do que ela sabe, só exprime isto: ele é" (FE, p. 74, § 91).

Hegel toma a riqueza e a pobreza da certeza sensível a partir do modo como ela se põe como conhecimento da verdade. A riqueza da certeza sensível está no fato de que, para ela, seu saber se refere imediatamente ao objeto e por isso identifica-se plenamente com ele. Nada do que existe Ihe escapa, pois ela capta justamente o que "é". Seu saber parece-lhe ilimitado, pois não encontra ente no espaço e no tempo que esteja para além de seu âmbito de apreensão.

Entretanto, a certeza sensível também parece ser o mais pobre saber, a partir da própria caracterização que faz de si. Sobre o objeto, nada mais tem a dizer do que "ele é". A base da certeza da verdade da consciência é o puro ser do objeto. Seu saber, assim, deve limitar-se a esse ser.

Esta é a situação ambígua em que se encontra a consciência. Visar o que simplesmente "é", por um lado, faz da certeza sensível o conhecimento pleno da verdade, pois para ela o objeto de seu saber é justamente esse ser puro. Mas, por outro lado, ao tomar o objeto como imediato, a consciência limita-se ao simples apontar para aquilo que quer referirse.

A base dessa situação, entretanto, é a forma com que a certeza sensível caracteriza o ato cognitivo e os elementos que estão em jogo nele. Conforme a argumentação hegeliana,

[...] nem o Eu nem a coisa tem aqui a significação de uma mediação multiforme. O Eu não tem a significação de um multiforme representar ou pensar, nem a Coisa uma significação de uma multidão de diversas propriedades; ao contrário, a Coisa é, e ela é esse puro ser, ou essa imediatez simples, constitui sua verdade. A certeza igualmente, enquanto relação, é pura relação imediata. A consciência é Eu, nada mais: um puro este. O singular sabe o puro este, ou seja, sabe o singular (FE, p. 75, § 91).

Já ficou indicado que o saber da certeza sensível é imediato, ou seja, possui seu objeto assim como ele é. Também já se afirmou que a partir disso deve-se concluir que a certeza sensível toma também seu objeto como imediato, pois toda mediação seria sinal de que não se está de posse do objeto mesmo, mas de algo que sofreu alguma influência por parte da consciência. Se o saber é imediato, a consciência não pode ter como conteúdo algo além do puro ser do objeto. Isso significa, por sua vez, que o ser do objeto constitui-se a partir de si mesmo, sem a influência de qualquer elemento estranho a ele. Se o ser do objeto fosse mediato, então deveria estar constituído apenas depois de um processo de mediação com outro. Entretanto, com isso a consciência não se apossaria de seu ser enquanto tal. Ela teria como conteúdo este ser mediado por algo outro que ele.

A questão é que um ser não singular não pode ser concebido sem algum tipo de mediação. Segundo a sugestão de Hegel, um objeto não singular poderia ser algo como uma "multidão de diversas propriedades". Entretanto, um objeto concebido de tal forma seria antes mediato, pois seu ser surgiria somente após a integração de um conjunto de propriedades. A existência de diversas propriedades só poderia ser detectada comparando o objeto com 
outros e as propriedades entre si. Isso significa que o conteúdo da consciência dependeria de um ato seu. Portanto, o ser apreendido não seria exatamente o objeto disponível. Ele só seria alcançado mediante a atividade consciente. Neste caso, porém, a correspondência imediata entre saber e objeto não se realizaria e o saber teria de ser considerado ilegítimo. Portanto, tomando como legítimo apenas o saber imediato, a certeza sensível tem de reduzir à pura singularidade a realidade a ser apreendida. Da mesma forma, o eu que apreende a verdade tem de ser igualmente singular. Se fosse uma reunião de pensamentos diversos, a caracterização do objeto apreendido seria resultado de um processo de mediação entre elementos da própria consciência. A imediatez do objeto implica que ele está disponível à consciência num ato singular de apreensão do eu.

Aliás, este é um passo essencial para a argumentação hegeliana. Como se disse na terceira seção do capítulo anterior, Hegel acredita que a consciência sempre dispõe de um padrão de medida a partir do qual o exame de seu saber pode ser realizado. Esse padrão de medida não pode ser outra coisa do que a própria verdade. O saber é, para a certeza sensível, a apreensão imediata do objeto. A princípio, esta consideração diz respeito apenas ao saber. Entretanto, implica, ou melhor, supõe uma certa noção de verdade: a singularidade do objeto e do eu que o apreende. Assim, agora a consciência dispõe também de um padrão de medida.

\subsection{A mediação fundamental: o eu e o objeto}

Prosseguindo a exposição da figura da certeza sensível, Hegel afirma o seguinte.

$$
\begin{aligned}
& \text { No entanto, há muita coisa ainda em jogo, se bem atendemos, no puro ser que } \\
& \text { constitui a essência dessa certeza, e que ela enuncia como sua verdade. Uma certeza } \\
& \text { sensível efetiva não é apenas essa pura imediatez, mas é um exemplo da mesma. } \\
& \text { Entre as diferenças sem conta que ali se evidenciam, achamos em toda parte a } \\
& \text { diferença-capital, a saber: que nessa certeza ressaltam logo para fora do puro ser os } \\
& \text { dois estes já mencionados: o este, como Eu, e um este como objeto (FE, p. } 75, \S 92 \text { ). }
\end{aligned}
$$

Há, portanto, segundo Hegel, uma diferença entre o puro ser que constitui a essência da certeza sensível e uma certeza sensível efetiva, que é um exemplo dessa imediatez. Para ela, o ser é imediato. Entretanto, ela mesma é apenas um exemplo dessa imediatez, ou seja, ela é apenas a expressão do objeto, mas não o objeto mesmo. Isso significa que há, além da pureza do objeto, ela mesma, enquanto sua representação imediata. Há, portanto, uma diferença entre o objeto e o sujeito que o apreende.

Isto é o que Hegel quer dizer quando afirma que há muito mais em jogo na imediatez pura tomada como essência pela certeza sensível: embora ela acredite que seu saber está unido imediatamente ao objeto a que se refere, nessa mesma pressuposição já está dito que há um saber e há um objeto a ser sabido. Ou seja, uma certeza sensível só tem sentido se diferencia o eu que conhece do objeto que é conhecido. Portanto, a rigor já se ultrapassou o momento da pura imediatez.

Para Hegel, essa diferenciação se apresenta à própria certeza sensível. Nela, 
[...] um momento é posto como o essente simples e imediato, ou como a essência: o objeto. O outro momento, porém, é posto como o inessencial e o mediatizado, momento que nisso não é em-si, mas por meio de um Outro: o Eu, um saber, que sabe o objeto só porque ele é; saber que pode ser ou não. Mas o objeto é o verdadeiro e a essência: ele é, tanto faz que seja conhecido ou não. Permanece mesmo não sendo conhecido - enquanto o saber não é, se o objeto não é (FE, p. 75, § 93).

Diante do fato de que ela não é a imediatez que toma como essência, mas apenas um exemplo da mesma, a certeza sensível conclui que no seu saber está em jogo a relação entre sujeito e objeto. Entretanto, ambos não estão nesta relação da mesma forma. Na medida em que ao eu cabe simplesmente apreender o objeto, sua existência é secundária, quer dizer, só surge à consciência mediante o aparecimento do objeto. Isso significa que ele (o saber) não é imediato, pois existe apenas por meio de outro. O objeto, por sua vez, é imediato. Seu ser está fundado nele mesmo.

É interessante observar que a ideia de imediatez é desde o início negativa, ou seja, significa ausência de mediação. Mediato é aquilo que "é" por meio de algo outro que ele. $O$ objeto é imediato porque, sendo a essência procurada pelo saber, tem de ser por meio de si mesmo. Se no saber houvesse algo estranho ao objeto, ele seria falso, pois não corresponderia plenamente ao que toma como verdade. O saber, por sua vez, também é imediato, porque não se constitui através de outro elemento além da pura essência do objeto. Entretanto, já há aí algum tipo de mediação. Embora corresponda imediatamente ao objeto, o saber é distinto dele e só existe por meio dele.

\subsection{A determinação do objeto (verdade): a singularidade}

A consciência busca o essencial, aquilo que é por meio de si mesmo. Para ela, isso significa que o objeto a ser apreendido é puramente singular, independente e indiferente a tudo mais. Realidades complexas são dependentes dos elementos que as constituem e só são conhecidas na medida em que a consciência compara e relaciona esses elementos. A consciência assume como tarefa, assim, verificar se seu saber alcança o que é para ela a verdade: o singular imediato. Ou, nas palavras de Hegel, "o objeto portanto deve ser examinado, a ver se é de fato, na certeza sensível mesma, aquela essência que ela lhe atribui; e se esse conceito - de ser uma essência - corresponde ao modo como se encontra na certeza sensível" (FE, p. 75, § 94).

Aqui é importante lembrar o que se disse na terceira seção do capítulo anterior. 0 exame que a consciência realiza é a comparação entre o saber e a verdade. Como se viu, esta última está presente também à consciência, na medida em que é necessariamente pressuposta como o elemento a que o saber tem de corresponder. No caso da certeza sensível, a verdade é o imediato, aquilo que é por si mesmo. Por isso Hegel a trata como essência. O objeto é o essencial porque tem em si mesmo o fundamento de seu ser. Inessencial é o que só "é" através de outro ser. Trata-se, como se pode ver, das mesmas ideias presentes nos conceitos de imediato e mediato.

O objeto está presente na certeza sensível como singularidade pura. E ele é uma essência, quer dizer, algo que é independentemente de tudo mais. O exame consiste em ver, 
portanto, se o modo como o objeto é tomado corresponde ao que ele é. E, como acrescenta Hegel, se seu ser apresenta-se na certeza sensível na forma como ela o considera. É nestes termos que o processo vai desenvolver-se. 


\section{AS EXPERIÊNCIAS DA CERTEZA SENSÍVEL}

Determinados os elementos que compõem a certeza sensível, tanto do lado do objeto quanto do lado do saber, cabe agora acompanhar o desenvolvimento das experiências dessa consciência. Verificar-se-á, portanto, como ocorre o exame descrito por Hegel no final da Introdução da Fenomenologia do espírito, como foi descrito no primeiro capítulo, em que será avaliada a adequação entre o saber e seu objeto.

\subsection{A primeira experiência: o desvanecer do isto}

Segundo Hegel, tudo começa quando a certeza sensível tem de responder à pergunta: "que é isto?" (FE, p. 76, § 95). Isso significa que a certeza sensível deve determinar mais de perto a singularidade que visa. Aqui ela deve verificar simplesmente se o objeto singular é a essência que ela procura e se aquilo que ela toma por essência é mesmo a pura singularidade sensível.

A pergunta pelo isto é a pergunta pela singularidade. No tempo, a singularidade deve ser buscada como um instante, ou seja, como agora. Assim, a pergunta pelo isto pode ser transformada na pergunta pelo agora. A resposta a essa pergunta, como sugere Hegel, poderia ser: "agora é noite" (FE, p. 76, § 95).

Nesse ponto, Hegel propõe uma experiência: anotar a verdade alcançada. Ora, a certeza sensível pensa estar de posse do ser. No tempo, essa essencialidade está presente como permanência. O que "é" em todos os instantes é aquilo que não desvanece com o passar do tempo, ou seja, é o que permanece. Assim, sendo a posse plena do ser, a certeza sensível tem de supor que seu objeto mantém sua essencialidade em todos os momentos. $A$ singularidade pura, representada pelo agora, tem de resistir à passagem do tempo.

A verdade foi anotada: o agora é noite. Entretanto, inevitavelmente o agora assim como foi anotado desvanece. Num instante seguinte, ele se converte num outro ser: o agora é dia. Mas, afirma Hegel, "o agora que é noite foi conservado, isto é, foi tratado como se ofereceu, como um essente; mas se mostra, antes, como um não-essente" (FE, p. 76, § 96). Assim, nenhum instante singular cumpre a exigência de ser o objeto que a certeza sensível visa, pois nenhum "é" em todo tempo. O agora como noite foi tomado como uma essência imediata. Entretanto, no momento seguinte, a essência é o agora como dia. Ora, se o agora como dia é a essência e é um outro ser em relação ao agora como noite, então o agora como noite não "é". O agora como noite desvaneceu, portanto. Tornou-se um não ser.

Observe-se que o exame desenvolveu-se aos moldes daquilo que Hegel anunciara. Tomou-se o objeto no modo como se apresenta na certeza sensível, ou seja, como 
singularidade (tratada como um instante do tempo). Verificou-se que ele, na forma como a certeza sensível o toma, não é a essencialidade visada. Descobriu-se, pois, um desacordo entre o modo como o objeto está na certeza sensível (singularidade) e o modo como a certeza sensível o concebe (essência). Como objeto singular, ele é evanescente. E a essencialidade, aquilo que permanece na certeza sensível, é justamente esse desvanecer de toda singularidade.

Em relação ao agora, já se concluiu a primeira tarefa, mencionada no final da parte anterior deste capítulo: saber se ele é uma essência. Como se viu, a conclusão é negativa. $O$ agora singular (como noite, por exemplo) é antes um não ser, algo que não "é". Cabe cumprir a segunda tarefa, isto é, descobrir como a essência está presente na certeza sensível. Aparentemente, pela experiência desenvolvida só se tem a conclusão negativa já salientada: o agora singular (este agora) é um não ser. E essa conclusão parece antes afirmar que não há essência alguma e que, portanto, a consciência apenas descobriu não estar de posse de qualquer verdade.

Entretanto, olhando mais de perto se pode perceber que a conclusão negativa tem também algo de positivo. A essência, em relação ao tempo, como se mostrou, é o que permanece. Ora, pela experiência desenvolvida descobriu-se também que algo permanece: o desvanecer dos instantes singulares. Todo agora singular (como noite, dia, etc.) torna-se um não ser. Mas esse desvanecer da singularidade não desvanece. Justamente ele é a essência que se mantém firme. Assim, o objeto que a certeza sensível visava ainda permanece. É verdade que não mais como ela o tomava anteriormente, isto é, como pura singularidade. $O$ agora se mantém como o que não é noite nem dia, o que Hegel chama de "negativo em geral" (FE, p. 76, § 96). Consequentemente, "esse agora que se mantém não é um imediato, mas um mediatizado, por ser determinado como o que permanece e se mantém porque outro - ou seja, o dia e a noite - não é" (FE, p. 76, § 96). O agora que se mantém "é" por meio do desvanecer de todo instante singular.

Para Hegel, "nós denominamos um universal um tal Simples que é por meio da negação; nem isto nem aquilo - um não-isto -, e indiferente também a ser isto ou aquilo. $O$ universal, portanto, é de fato o verdadeiro da certeza sensível” (FE, p. 76, § 96). Aqui se revela o engano em que a certeza sensível estava imersa. Ela visava o singular, pensando poder encontrar aí o objeto como uma essência. Entretanto, agora percebe que o singular não se mantém e por isso não é a essência firme que procurava. Para ela, isso significa que um novo objeto foi encontrado. A verdade pela qual sempre procurou agora se mostra de forma plena.

Até mesmo o sensível, tomado como verdade pela figura da consciência em questão, mostra ser diferente do modo como é considerado por ela. Nas palavras de Hegel:

Enunciamos também o sensível como um universal. O que dizemos é: isto, quer dizer, o isto universal; ou então: ele é, ou seja, o ser em geral. Com isso, não representamos, de certo, o isto universal ou o ser em geral, mas enunciamos o universal (FE, p. 76, § 97).

Dizendo o sensível, mesmo que se pretenda indicar o singular (isto), se está dizendo o universal. Ao dizer "isto" ou que aquilo que está à frente "é", a certeza sensível apenas 48 
enuncia o isto universal ou o ser em geral. Em outras palavras, o fato é que sob o "isto" todos os seres são compreendidos e não apenas aquele que é indicado.

Como se viu, nesse ponto Hegel diferencia o enunciar (ausprechen) do representar (vorstellen). Ao indicar o sensível como essência, embora este não seja alcançado, aquele sem dúvida é. O fato é que a consciência, ao tomar o sensível como sua verdade, embora vise o singular, enuncia um universal. Sensível não é este ou aquele objeto. É, portanto, um universal. Logo, indicando o sensível como essência, a certeza sensível enuncia um universal. Entretanto, a representação que faz do que é enunciado é outra. Para ela, o conteúdo compreendido no sensível é a singularidade por ela visada.

A experiência que foi realizada com o agora se desenvolve também a partir do outro aspecto do isto: o aqui, a singularidade espacial.

O aqui, por exemplo, é a árvore. Quando me viro, essa verdade desvaneceu, e mudou na oposta: o aqui não é uma árvore, mas antes uma casa. O próprio aqui não desvanece, mas é algo que fica, no desvanecer da casa, da árvore etc.; e indiferente quanto a ser casa ou árvore. Assim o isto se mostra de novo como simplicidade mediatizada, ou como universalidade (FE, p. 77, § 98).

O movimento é o mesmo ocorrido com o agora. A certeza sensível toma o aqui como algo singular, mas percebe que nisso ele é um evanescente: o aqui como árvore desvanece. Mas o aqui que para a certeza sensível é a essência ainda permanece, embora não mais como árvore, casa ou tudo mais de singular. $O$ aqui que permanece é o resultado da negação de tudo o que é singular. Assim, na medida em que se constitui por meio da negação, é antes um ser mediatizado. $O$ aqui como uma essência simples ainda está presente. Porém, não mais como singularidade imediata. $\mathrm{O}$ aqui que permanece é um universal.

\subsection{A segunda experiência: o desvanecer do eu}

Entretanto, para a consciência a verdade é o imediato. Para ela, portanto, o resultado dessa primeira série de experiências mostra apenas que não se pode encontrar a verdade nos objetos singulares visados. $\mathrm{O}$ objeto singular, não sendo imediato, não é verdadeiro. Mas ainda resta algo de imediato: o próprio eu que indica um objeto. Assim, "agora (...) a força de sua verdade está no Eu, na imediatez de meu ver, ouvir etc. O desvanecer do agora e do aqui singulares, que visamos, é evitado porque Eu os mantenho. O agora é dia porque Eu o vejo; o aqui é uma árvore pelo mesmo motivo" (FE, p. 77, § 101). O imediato é a verdade, para a certeza sensivel. E ela acredita que o eu que indica o objeto apresenta-se aí como singularidade pura. Por isso, já que o objeto singular desvanece, deve ser o eu o que sustenta a essencialidade procurada. Ou seja, embora o agora como noite desvaneça ao raiar do dia, ele está presente no saber como uma essência porque é sustentado pelo eu que o intui.

Com isso, a relação entre eu e objeto se inverte. Antes o objeto deveria ser o imediato. Agora ele depende da consciência e assim é mediato. Ele só se mantém enquanto objeto de uma consciência. $O$ fato é que a consciência verificou que o objeto singular não é a essência. Diante dessa descoberta, teve de procurar aquilo por meio do qual ele "é". O que equivale a dizer que ela teve de buscar aquilo que "é" por meio de si próprio, quer dizer, a essência. Se o 
objeto é um desvanecer, mas mesmo assim está presente na certeza sensível (ela tem certeza de tê-lo intuído), então quem o sustenta deve ser o próprio intuir. O eu e seu ver, olhar, etc. devem ser, assim, essenciais. Entretanto, como afirma Hegel,

[...] a certeza sensível experimenta nessa relação a mesma dialética que na anterior. $\mathrm{Eu}$, este, vejo a árvore e afirmo a árvore como o aqui; mas um outro Eu vê a casa e afirma: o aqui não é uma árvore, e sim uma casa. As duas verdades têm a mesma credibilidade, isto é, a imediatez do ver, e a segurança e afirmação de ambos quanto a seu saber; uma porém desvanece na outra (FE, p. 77, §101).

Quando a consciência toma seu próprio visar como essência, supõe que ele seja o que sustenta o objeto evitando seu desvanecer. Entretanto, o que um indivíduo intui não é o mesmo que outros intuem. Consequentemente, cada eu sustenta uma verdade diferente. Mas todos são, segundo a certeza sensível, igualmente imediatos. Todos são o eu que se dizia ser a essência. Assim, a consciência tem de concluir que o eu enquanto tal, que tem certeza da verdade, não é este eu que vê a casa, nem aquele que vê a árvore. O eu mesmo tem de ser indiferente a essas coisas que são postas como verdades. O eu que se sustenta não pode ligar-se a um intuir singular, mas ao próprio intuir como algo universal. Observe-se a exposição hegeliana:

O que nessa experiência não desvanece é o Eu como universal: seu ver, nem é um ver da árvore, nem o dessa casa; mas é um ver simples que embora mediatizado pela negação dessa casa etc., se mantém simples e indiferente diante do que está em jogo: a casa, a árvore (FE, p. 78, § 102).

Novamente, a singularidade não se apresenta como a certeza sensível queria, ou seja, como uma essência. O sujeito, enquanto singular, mostra-se como um evanescente. Este sujeito, que está vendo esta árvore, não pode sustentar a certeza da verdade. Ele desvanece, pois outros sujeitos podem afirmar, com a mesma credibilidade, que para eles a verdade é outra. O que se mantém, entretanto, é a necessidade de um sujeito na certeza sensível. Ou seja, mesmo diante do fato de que um sujeito singular não pode ser a essência da certeza sensível, o sujeito como tal ainda é necessário. Mas agora ele não pode mais ser tomado como um singular imediato. Na medida em que resulta da negação do singular, ele é por meio daquilo que desvanece. Então, ele é um mediatizado. E, como se viu, ao ente simples que "é" por meio da negação Hegel dá o nome de universal. Assim, o eu posto como essência da certeza sensível é um universal.

\subsection{A terceira experiência: o desvanecer da certeza singular}

Mas, a esta altura, a consciência ainda não abandonou sua pretensão de encontrar o puro ser imediato que considera verdadeiro. Ela já está convencida, é verdade, de que nem o objeto, nem o eu podem ser a essência procurada. Entretanto, a certeza sensível imagina que ela mesma, enquanto certeza singular, é capaz de manter-se como essencial. Embora sujeito e objeto não estejam presentes como imediatidades, o intuir mesmo deve estar. Com isso, ela deixa de levar em conta a alteridade que apareceu em relação ao objeto e ao sujeito. Não 
interessa que ao lado do agora como casa apareça o agora como árvore. Também não interessa que vários sujeitos tenham pontos de vista diferentes em relação à verdade. $\mathrm{O}$ que interessa é que ao menos o ato de indicar o objeto é imediato. Nas palavras de Hegel:

\begin{abstract}
Eu, este, afirmo assim o aqui como árvore, e não me viro de modo que o aqui se tornaria para mim uma não-árvore. Também não tomo conhecimento de que um outro Eu veja o aqui como não-árvore, ou que Eu mesmo em outra ocasião tomasse o aqui como não-árvore, e o agora como não-dia. Eu, porém, sou um puro intuir; eu, quanto a mim, fico nisto: o agora é dia; ou então neste outro: o aqui é árvore. Também não comparo o aqui e o agora um com o outro, mas me atenho firme a uma relação imediata; o agora é dia (FE, p. 78-9, §104).
\end{abstract}

Nas tentativas anteriores, a certeza sensível percebeu a inverdade de sua posição quando aquilo que ela tomava como essência mostrou ser evanescente. A noite, por exemplo, deveria ser essencial porque era o agora, isto é, o momento imediatamente dado. Porém, o agora também pode ser dia. A essencialidade do agora como noite foi negada, portanto, pelo aparecimento de um agora que não é noite. Se o agora é dia, não é noite. Logo, o agora como noite é um não ser. $O$ agora na sua singularidade desvanece. Resta apenas o agora universal que, entretanto, por ser mediato não é aceito como verdade pela certeza sensível. $O$ último recurso da certeza sensível é verificar se não resta mesmo nada de imediato. Para ela, ao menos uma coisa há: o ato singular de intuir o objeto. Quando toma a essência como casa, pode muito bem ser verdade que o ser indicado aí não é imediato, pois sob ele desvanecem todos os entes singulares. Da mesma forma, o sujeito essencial do visar pode não ser imediato, na medida em que ele só permanece como aquele que não assume nenhum dos pontos de vista singulares. Entretanto, para ela $\mathrm{o}$ ato pelo qual um sujeito singular concebe um objeto singular é imediato. Ao lado do sujeito e do objeto envolvidos nele, podem surgir outros, fazendo com que estes desvaneçam enquanto essencialidades singulares. Entretanto, o ato mesmo, em sua singularidade, não pode ser negado por coisa alguma, justamente por ser tomado como absolutamente singular. Por exemplo, se o primeiro ato de tomar o agora como árvore é sucedido por um segundo, em que o agora é casa, a verdade do primeiro não é por este negada, pois se trata de um outro ato. Naquela intuição específica, em que o agora é casa, a verdade conserva sua imediatez.

Este último refúgio da certeza sensível, entretanto, em que a essência é tomada em sua totalidade imediata, também tem de ser abandonado. É claro que não mais como antes, em que se comparava o agora que é noite com o agora que é dia, ou o eu para quem o aqui é uma árvore com o eu que o intui como uma casa. É preciso assumir a singularidade absoluta do sujeito e do objeto. É preciso penetrar no mesmo lugar do espaço e no mesmo instante do tempo e ver o mundo simplesmente do ponto de vista de um eu único que intui um só e singular objeto. No entanto, mesmo nessa imediatez absoluta uma exigência tem de ser cumprida: é preciso que a certeza sensível indique a verdade postulada. Isso porque,

a verdade desse Eu não teria a mínima significação se a captássemos posteriormente ou se ficássemos distante dela; pois lhe teríamos suprassumido a imediatez que lhe é essencial. Devemos, portanto, penetrar no mesmo ponto do tempo ou do espaço, 
mostrá-los a nós, isto é, fazer de nós [um só e] o mesmo com esse Eu que-sabe com certeza (FE, p. 78-9, § 104).

Se, para a certeza sensível, a verdade é a pura imediatez da apreensão, é preciso que essa verdade se evidencie imediatamente a toda consciência. Se não for possível apreendêla, fica claro que ela não é imediata, ou seja, evidente em si mesma. Do mesmo modo, se isso só puder ser feito posteriormente, então ela não é a pura imediatez que se diz que é. Apreender posteriormente significa que está posto, entre o ato da consciência que apreende $\mathrm{e}$ a verdade mesma, algo outro que ela, que tem de ser assimilado antes. Nesse caso, a verdade indicada não é imediata, pois surge somente através de um outro. Desse modo, a pura imediatez que a certeza sensível diz possuir, mesmo que seja mantida indiferente a outros seres singulares apreendidos e à certeza de outros sujeitos, tem de ser ao menos indicada. A certeza sensível é, por seus próprios pressupostos, desalojada de sua pura certeza da verdade, tendo de indicar o que toma como evidente.

\subsection{0 universal como a verdade da certeza sensível}

Mas, como ficou claro na terceira seção do primeiro capítulo, no desenvolvimento fenomenológico a descoberta do engano não tem sentido apenas negativo. Quando uma verdade desvanece, seu próprio desvanecer engendra o aparecimento de sua substituta. No caso da certeza sensível, isso se evidencia no próprio ato pelo qual a consciência indica o que é a verdade. Para ela, o agora é a verdade, por exemplo. Indicando-o, assim, ela imagina estar apontando para uma essência. Entretanto, no ato de indicar o agora, ele já passou, não "é" mais. O agora, é claro, ainda resta, mas não como foi indicado. Ele permanece como outro do que se indicou. Observe-se a exposição hegeliana:

1) indico o agora, que é afirmado como o verdadeiro; mas o indico como o-que-já-foi, ou como um suprassumido. Suprassumo a primeira verdade, e:

2) agora afirmo como segunda verdade que ele foi, que está suprassumido.

3) mas o-que-foi não é. Suprassumo o ser-que-foi ou o ser-suprassumido - segunda verdade; nego com isso a negação do agora e retorno à primeira afirmação de que o agora é (FE, p. 79, § 107).

A certeza sensível toma como essência certo instante singular. Ela não o compara com outros instantes, nem leva em conta outras opiniões. Mantém o agora indicado como essência firme. Entretanto, é necessário que ela mostre que verdade é essa. Mas o agora que ela tomou como verdade só pode ser indicado como o que já foi, ou seja, como outro instante em relação ao momento presente. O agora indicado, portanto, é um não ser. Isso significa que ele é o oposto do objeto enquanto essencialidade. Entretanto, a consciência procurava o essencial. Então, ela precisa encontrar o agora como algo essencial, permanente. E o agora "é" o que já foi. Através disso, a consciência recupera a essencialidade que buscava.

Entretanto, como assinala Hegel, "esse primeiro refletido em-si mesmo não é exatamente o mesmo que era de início, a saber, um imediato; ao contrário, é propriamente algo em-si refletido ou um simples, que permanece no ser-Outro o que ele é: um agora que é absolutamente muitos agoras" (FE, p. 79-80, §107). Antes o agora era tomado como um 
instante singular. Esse agora, entretanto, já foi, não "é" mais. O que permanece, e deve assumir o lugar da essência procurada pela certeza sensível, é esse desvanecer da singularidade. O agora que "é" tem suprassumida no seu ser uma multidão de instantes singulares por meio dos quais se constitui. Mas ele é ao mesmo tempo simples, isto é, não tem diferenças em si mesmo. $O$ fato de ele ser constituído por diversos instantes singulares não faz dele uma realidade complexa, pois a essência desses instantes é apenas uma: o agora que permanece sempre. O agora só não seria simples se fosse constituído por diversos seres. Mas os instantes singulares não são seres. Quando se busca o agora que "é" , como se mostrou, observa-se o desvanecer de todos os instantes singulares e o consequente surgimento da universalidade como essência deles. Logo, só resta no agora uma essência, que é o que se mantém em meio ao desvanecer dos instantes singulares.

O mesmo ocorre com o aqui. "O aqui indicado, que retenho com firmeza, é também um este aqui que de fato não é este aqui, mas um diante e atrás, um acima e abaixo, um à direita e à esquerda" (FE, p. 80, § 108). Assim como um instante singular não pode ser a essência, também a singularidade espacial mostra ser evanescente. Quando a consciência indica o aqui, ela imagina estar apontando para uma essência imediata. Entretanto, no seu ato todos os pontos do espaço são também indicados. Assim, o aqui singular indicado só pode ser determinado como o oposto de todos os demais pontos. Mas, ao dizer que ele, enquanto singular, é essencial, está-se afirmando que todos os pontos são igualmente essenciais. $\mathrm{Na}$ medida em que são diferentes, cada um é um não-ser em relação ao outro. Pondo o ser neles mesmos, assim, eles acabam por converter-se no oposto, ou seja, desvanecem.

A verdade desse processo é que a singularidade espacial desvanece. Um ponto singular no espaço só pode ser determinado na medida em que não é todos os outros. Isso significa que, enquanto é a essência, faz todos os outros desvanecerem; pois, sendo a essência e distinto dos demais, faz destes o oposto do que é essencial. Mas, sendo singular como os outros, desvanece junto com eles. A razão desse desvanecer está no fato de que pelo indicar a consciência alcança o oposto do que é visado. Ela quer a singularidade, mas tomando o "aqui" como essencial está referindo-se a todos os pontos do espaço. Então, pelo indicar, ao invés de fixar o ponto ao qual quer referir-se, a consciência mostra que este ponto não é aquele que deve ser tomado como a essência do saber de que dispõe. O objeto do saber deveria manter-se como sua essência. Entretanto, o ponto singular desvanece, pois é outro em relação ao que é igualmente singular e que, por isso, deveria também ser tratado como essencial. A essência procurada, assim, não pode ser singular. Mas o saber de que dispõe agora a consciência toma um novo objeto como verdade: a simplicidade que permanece no desvanecer dos pontos singulares. A certeza anterior, de que a verdade é um objeto imediato, foi descartada. Nisso a consciência não só refutou sua visão anterior. Ela também se apossou de um novo objeto, que é justamente o que se revelou essencial na experiência desenvolvida: o fato de a singularidade desvanecer. O aqui singular não é essencial. Mas é essencial que haja um aqui. Não este ou aquele, é verdade, mas o aqui enquanto tal, que, justamente por não ser este ou aquele, é universal.

A partir dessa experiência, Hegel quer criticar a posição que defende "que a realidade ou o ser das coisas externas, enquanto estas ou enquanto sensíveis, tem uma verdade absoluta 
para a consciência". Para ele, "uma afirmação dessas não sabe o que diz; não sabe que diz o contrário do que quer dizer" (FE, p. 80, § 109). Mais adiante ele mostra as razões daquilo que está afirmando. Conforme a experiência apresentada na certeza sensível, "quando o que se diz de uma coisa é apenas que é uma coisa efetiva, um objeto externo, então ela é enunciada somente como o que há de mais universal, e com isso se enuncia mais sua igualdade que sua diferença com todas as outras" (FE, p. 82, § 110). Poder-se-ia dizer que, se a Fenomenologia fosse uma obra destinada simplesmente à defesa de uma tese, o enunciado básico de seu primeiro capítulo seria esse último. Aí está presente o cerne daquilo que acontece com a consciência que se apresenta como certeza sensível.

A certeza sensível toma como verdade aquilo que se apresenta. Sua certeza da verdade tem como base, assim, o puro ser do objeto. Justamente por isso é sensível, ou seja, é alcançada pela consciência através de uma atividade meramente receptiva. Como consequência, ela deve evitar qualquer consideração que tome o objeto a partir de sua relação com outro. Se o objeto fosse concebido através de algum tipo de comparação, composição, etc., então a consciência não estaria de posse de seu ser próprio, mas de um conteúdo constituído por algum tipo de influência sua. Isso significa que o objeto só pode ser concebido como uma singularidade pura, isto é, como uma entidade cuja essência é absolutamente própria e indiferente a tudo mais.

A experiência que se desenvolve na certeza sensível, como se pôde ver, ocorre nos termos daquilo que Hegel afirmou acima. O fato é que, quando a consciência diz que a verdade é o singular, o sensível, o isto, a árvore, etc., não toma como objeto de seu saber algo de singular ou imediato. Tudo isso remete não a uma essência única. Muito pelo contrário, salienta somente o que há de comum a uma multidão de coisas. Por isso, como mostra Hegel, quando se diz que o singular é a verdade, está-se afirmando o oposto do que se quer, pois o conteúdo que é tomado como verdade, que é propriamente a caracterização do objeto do saber, é um universal, ou seja, diz respeito não a esta ou àquela coisa, mas antes a uma porção delas.

Com isso, a consciência deixa de ser certeza sensível. Ela buscava o imediato, aquilo que é por si mesmo. Ela imaginou poder encontrar isso nos objetos singulares. Entretanto, ao indicá-los, o que se mostrou essencial foi a universalidade que os abarca. Esta deve ser para ela, agora, a verdade. Mas, com isso, ela deixa de ser certeza sensível para tornar-se percepção. 
CAPÍTULO III

A AUTOCRÍTICA DA PERCEPÇÃO 


\section{A ESTRUTURA DA PERCEPÇÃO}

Neste terceiro capítulo, será apresentada a segunda figura da Fenomenologia do espírito: a percepção. Em primeiro lugar, serão descritos os elementos que compõem a estrutura desta forma de consciência e, em segundo, as experiências pelas quais ela passa na sua tentativa de apossar-se de seu objeto.

Nesta primeira seção, verificar-se-á como o objeto e o saber da percepção se constituem a partir das experiências da certeza sensível. A universalidade, que é o resultado desta figura, impõe à percepção a necessidade de conceber o verdadeiro, o essencial, como o uno que retorna a si, que se mantém, pela superação da multiplicidade. Encarnando esse critério, o objeto será a coisa de muitas propriedades, que conterá em si tanto o momento da diferença, quanto o da identidade.

\subsection{Do visar ao perceber}

Quando a certeza sensível descobre que a verdade que deve ser tomada como objeto de seu saber é a universalidade, ela se torna percepção. Percepção, assim, é uma forma determinada de a consciência relacionar-se consigo mesma e com seu objeto, que surge no momento em que a verdade é tratada como um universal. A partir da experiência desenvolvida, a certeza sensível conclui que a verdade sempre foi o universal. A diferença é que antes ela estava imersa num engano, enquanto agora está de posse da verdade na sua forma própria.

A percepção, assim, "toma como universal o que para ela é o essente. Como a universalidade é seu princípio em geral, assim também são universais seus momentos, que nela se distinguem imediatamente: o Eu é um universal, e o objeto é um universal" (FE, p. 83, $\S 111)$. Enquanto certeza sensível, a consciência experimentou o fato de que, tanto o objeto, quanto o eu, que já eram distinguidos nesta figura, só são verdadeiros enquanto universalidades. Por isso, ambos são tratados, na percepção, como universais.

Entretanto, para o filósofo uma consideração mais acurada pode ser feita. As experiências pelas quais passou a certeza sensível não serviram apenas para que ela se apossasse da verdade. No fundo, elas forneceram a totalidade do novo conteúdo da consciência. Isso significa que o modo como a consciência toma o objeto e o próprio sujeito que o percebe constituiu-se a partir do indicar da certeza sensível. Para Hegel, eles são "um, o movimento do indicar; outro, o mesmo movimento, mas como algo simples: o primeiro, o perceber; o segundo o objeto" (FE, p. 83, § 111). No movimento do indicar, a verdade como universalidade foi constituída, pois foi nele que o sensível singular desvaneceu. Mas o indicar, mesmo a partir do ponto de vista da certeza sensível, supõe dois elementos: sujeito e objeto. 
Em primeiro lugar, a certeza sensível descobriu que o eu que se apossa da verdade não é singular. $O$ indicar do sujeito, pelo qual ele deveria conhecer a verdade, assim, torna-se universal. É agora o perceber. Esse mesmo processo define o objeto. Entretanto, o perceber supõe uma relação entre sujeito e objeto, enquanto o objeto constitui-se a partir de si mesmo. Por isso, seu conteúdo é também o movimento do indicar, mas como algo simples. Essa simplicidade diz respeito não apenas à sua anterioridade em relação ao sujeito, como também ao fato de não conter diferença alguma em si mesmo. Como se viu no capítulo anterior, o universal, que surge como verdade na certeza sensível, é simples. Um instante singular não está presente no agora universal como uma diferença. Pelo contrário, na medida em que é simplesmente um "agora", seu ser coincide com o de todos os demais instantes e, por isso, com a universalidade. Consequentemente, o agora na sua forma essencial não tem diferença alguma em si mesmo, ou seja, é simples.

\subsection{A diferença entre sujeito e objeto}

Entretanto, essa forma de conceber sujeito e objeto já traz um primeiro impasse. Como afirma Hegel, “... por serem ambos o universal ou a essência, os dois são essencialmente. Mas enquanto se relacionam como opostos um ao outro, somente um pode ser o essencial na relação" (FE, p. 83, § 111). Tanto o perceber, quanto o objeto, na medida em que são universais, estão na consciência como essências. Mas a percepção, assim como a própria certeza sensível, é capaz de distinguir de si o objeto. Isso significa que ele é um outro ser em relação a ela. Ora, sendo distintos, só um pode ser a essência. Então, "um, determinado como simples - o objeto - é a essência, indiferente a ser ou não percebida; mas o perceber, como o movimento, é o inconsistente, que pode ser ou não ser, e é o inessencial” (FE, p. 84, § 111). O universal foi posto a partir do desvanecer da singularidade. Como já se afirmou, ele é simples, pois no seu ser não há diferença alguma. Na percepção, sujeito e objeto, enquanto universais, são também simples. Entretanto, o perceber do sujeito realiza menos essa simplicidade do que o objeto percebido. Pois o perceber, na medida em que é um movimento entre sujeito e objeto, assume em seu âmago esses dois elementos como duas essências distintas. Por outro lado, o objeto não supõe relação alguma. Ele "é" indiferentemente de ser percebido ou não. Assim, por ser o mais simples é também o mais essencial.

\subsection{A coisa de muitas propriedades}

Mas o objeto da percepção deve ser caracterizado ainda mais de perto. Segundo Hegel, "o princípio do objeto - o universal - é em sua simplicidade um mediatizado; assim tem de exprimir isto nele, como sua natureza: por conseguinte se mostra como a coisa de muitas propriedades" (FE, p. 34, § 112). A percepção toma o objeto como um universal. E o objeto é o simples, o reunido num só. Assim, no próprio objeto, independentemente de tudo mais, deve estar a mediação (negação), alcançada como sua verdade ao final da experiência da certeza sensível. O modo de fazer isso é conceber o objeto como uma coisa (simplicidade) que tem em si a mediação (propriedades). 
É bom lembrar que o universal, que agora é tomado como verdade, surgiu de um processo de negação da singularidade sensível. O agora, por exemplo, mostrou ser, enquanto essencial, não este ou aquele instante, mas um universal. Desvaneceu, portanto, sua singularidade. Como se mostrou, os instantes singulares desvanecem porque o que é posto como a essência deles no indicar é o universal. Então, é no universal que a essência dos instantes singulares deve ser encontrada. E, como era da singularidade sensível que se tratava, no universal "ainda está presente o sensível mesmo, mas não como devia estar na certeza imediata - como um singular visado -, e sim como universal, ou como o que será determinado como propriedade" (FE, p. 34, § 113). A propriedade, assim, é um universal sensível. A cor branca, por exemplo, não é uma singularidade, pois diz respeito a uma multidão de seres distintos. Da mesma forma, ela está presente sensivelmente nos objetos.

As várias propriedades presentes na coisa, por serem universais, são também essenciais. Cada uma constitui-se de uma essencialidade própria. Isso significa que são entre si distintas. Como consequência, conforme afirma Hegel, "estão postas ao mesmo tempo muitas propriedades desse tipo, sendo uma o negativo da outra" (FE, p. 34, § 113). O universal é um elemento simples (sem diferenças internas) que se mantém pelo desvanecer da singularidade. Isso significa que ele tem em si mesmo a base de seu ser. Então, cada propriedade, ao ser ela mesma, não é todas as outras. Há, assim, entre elas uma relação de negação.

\subsection{A coisa: meio indiferente e uno excludente}

A partir dessas determinações, a coisa se constitui para a consciência. Em primeiro lugar, afirma Hegel, "[...] expressas na simplicidade do universal, essas determinidades [...] relacionam-se consigo mesmas, são indiferentes umas às outras: cada uma é para si, livre da outra" (FE, p. 34, § 113). Novamente é necessário recordar como foi constituída a universalidade que a percepção toma como princípio e determina como propriedade. A singularidade, na certeza sensível, foi posta como essencial. Entretanto, ao lado de um ponto singular surgia outro, que deveria ser igualmente essencial. Isso foi o que tornou a singularidade inessencial. $O$ universal surgiu como o que reúne esses diversos pontos num elemento simples. Foi justamente isto o que fez do universal uma essência: ao contrário do que ocorre com os entes singulares, ao seu lado não surge outro igualmente essencial. $O$ universal, assim, reúne em si as diversas diferenças que estão presentes na certeza sensível. Como consequência, ao seu lado não pode haver diferença alguma. Por isso é que as propriedades, por serem universais, devem ser indiferentes entre si. Uma não pode pôr-se ao lado da outra como um outro ser.

Mas, afirma Hegel, diante dessa multiplicidade de propriedades,

a universalidade simples, igual a si mesma, é de novo distinta e livre dessas determinidades: é o puro relacionar-se-consigo ou meio, onde são todas essas determinidades. Interpenetram-se nela como numa unidade simples, mas sem se tocarem; porque são indiferentes para si, justamente por meio da participação nessa universalidade (FE, p. 34-5, § 113). 
Na medida em que as propriedades, por serem universais, são indiferentes entre si, a relação que estabelecem é justamente de indiferença. A coisa de que são propriedades, portanto, deve ser tomada como esse meio simples onde não há diferenças. Embora haja uma multidão de propriedades, todas têm de ser constitutivas da mesma coisa, sem que uma interfira na outra. Hegel fornece, inclusive, um exemplo de como seria compreendida a coisa a partir desse modo de conceber a objetividade.

Este sal é um aqui simples, e ao mesmo tempo múltiplo; é branco e também picante, também é cubiforme, também tem peso determinado etc. Todas as propriedades múltiplas estão num aqui simples no qual assim se interpenetram: nenhuma tem um aqui diverso do da outra, pois cada uma está sempre onde a outra está. Igualmente, sem que estejam separadas por aquis diversos, não se afetam mutuamente por essa interpenetração. [...] Esse também é portanto o puro universal mesmo, ou o meio: é a coisidade que assim engloba todas essas propriedades (FE, p. 85, § 113).

Como as propriedades não se influenciam entre si, têm de estar todas juntas na simplicidade da coisa. O fato de serem diversas não torna o meio em que estão múltiplo, pois nele não fica ressaltada a diferença que há entre elas, justamente porque são indiferentes entre si. A coisa, assim, é elevada a um "também", ou seja, a um meio em que todas as propriedades simplesmente estão, sem que uma entre em relação de distinção com a outra.

Entretanto, não é só isso que é exigido para a constituição do objeto (da coisa de muitas propriedades). Segundo Hegel, a consciência logo se dá conta de que

\footnotetext{
[...] se as muitas propriedades determinadas fossem-simplesmente indiferentes, e se relacionassem exclusivamente consigo mesmas, nesse caso não seriam determinadas. [...] Mas, segundo essa oposição, não podem estar juntas na unidade simples de seu meio, que lhes é tão essencial quanto a negação. A diferenciação dessa unidade - enquanto não é uma unidade indiferente, mas excludente, negadora do Outro - recai assim fora desse meio simples. Por isso, esse meio não é apenas um também, unidade indiferente; mas é, outrossim, o Uno, unidade excludente (FE, p.85, § 114).
}

O caráter determinado de uma propriedade implica necessariamente na sua distinção em relação às demais. Em outras palavras, se a propriedade é ela mesma, então não é todas as outras. Com isso fica explícito o fato de as propriedades não se relacionarem de modo indiferente entre si. Cada uma, ao ser ela mesma, nega todas as outras. Estando envoltas, por sua vez, nessa relação de oposição, não podem apenas coexistir num meio simples indiferente, como tinha sido caracterizada a coisa anteriormente. A coisa deve ser determinada, portanto, como a unidade que se constitui a partir da relação negativa entre suas propriedades.

A coisa da percepção, assim, estrutura-se a partir de uma dupla necessidade. Por um lado, tem de ser o meio em que todas as propriedades coexistem. Mas, por outro, tem de ser um uno excludente, em que essas propriedades, enquanto determinadas, negam-se mutuamente. Por isso, assinala Hegel,

[...] essas diferenças [as propriedades], pelo seu aspecto de pertencerem ao meio indiferente, são universais elas mesmas, só consigo se relacionam e [mutuamente] não se afetam. Mas pelo aspecto de pertencerem à unidade negativa são, ao mesmo tempo, excludentes, e contudo têm necessariamente esse relacionamento de oposição para com propriedades que estão afastadas de seu também (FE, p. 86, § 115). 
As propriedades, pelo fato de serem universais, são o elemento em que toda diferença está suprassumida. Isso significa que nenhuma diferença pode ser posta em relação a elas. Consequentemente, a coisa deve ser simplesmente o meio em que todas as propriedades estão, sem que uma interfira na outra. Entretanto, por serem determinadas, as propriedades se opõem entre si. Ora, se são opostos, a coisa não pode ser tomada simplesmente como meio indiferente. Ela é antes a unidade resultante do processo de negação recíproca das propriedades. Por outro lado, como assinala Hegel por último, não se poderia deixar de concebê-las como pertencentes a esta unidade, pois também é preciso que as propriedades pertencentes ao meio sejam distinguidas daquelas que estão afastadas e não pertencem a ele.

Com isso, a consciência agora sabe que "a universalidade sensível ou a unidade imediata do ser e do negativo só é propriedade enquanto o Uno e a universalidade pura se desenvolvem nela, e se diferenciam entre si, e ela os engloba juntamente, um com o outro" (FE, p. 86, § 115). A universalidade sensível, que é o princípio fundamental da percepção, é "a unidade imediata do ser e do negativo". Isso se deve ao fato de o universal ter surgido como a essência (ser) que permanece mediante o desvanecer (negativo) dos elementos singulares. Essa universalidade sensível está presente na percepção na forma de propriedade. A propriedade é, assim, um universal sensível. Isso significa que ela mesma tem de ser a unidade imediata entre o ser e o negativo. Sob o primeiro aspecto, por sua vez, ela é um ente determinado. Como consequência, a coisa torna-se a unidade que resulta da mútua oposição entre as propriedades. Mas, em relação à negatividade, ela é simplesmente universal, ou seja, é a suprassunção de todas as diferenças, negativas entre si, encontradas na certeza sensível. Consequentemente, não resta em relação a ela nenhuma diferença e a coisa torna-se uma universalidade pura, isto é, um meio cujos elementos constitutivos são entre si indiferentes.

\subsection{0 universal como critério de verdade e a ilusão}

A partir desses elementos, a coisa está constituída, bastando à consciência apenas percebê-la. Como se disse anteriormente, o objeto é o essencial, aquilo que "é" primordialmente, enquanto o perceber pode ser ou não ser. A percepção é legítima quando se apossa do essencial, do objeto como é em-si. Entretanto,

[...] a consciência percebente é cônscia da possibilidade da ilusão, pois na universalidade, que é [seu] princípio, o ser-Outro é para ela, imediatamente: mas enquanto nada, [como] suprassumido. Portanto, seu critério de verdade é a igualdadeconsigo-mesmo, e seu procedimento é apreender o que é igual a si mesmo (FE, p. 86, $\S 116)$.

A expressão "ser-Outro" está vinculada, neste contexto, à ideia de diferença. Na certeza sensível, por exemplo, o agora como dia é um "ser-outro" em relação ao agora como noite. Ou seja, o agora como dia é um ser diferente do agora como noite. Como se sabe, visando o agora como noite, ao invés de apossar-se de uma essência, a certeza sensível descobriu que seu objeto é algo inessencial. Tanto o agora como noite, quanto o agora como dia desvanecem. E a razão fundamental desse desvanecer está justamente no fato de que ao 
lado daquilo que é posto como essência surge um outro ser ("ser-outro"), que deveria ser igualmente essencial. $O$ resultado dessa experiência, como já se mostrou, é que só o universal pode ser tomado como essência. E ele é justamente a essência daqueles elementos que, enquanto singulares, são evanescentes. Isso significa que a percepção, que parte dos resultados das experiências da certeza sensível, leva em consideração a diferença, o "seroutro". Mas, segundo o universal, que é seu princípio, essa diferença é sinônimo de desvanecimento. Para ela, aquilo que tem ao seu lado um ser oposto acaba inevitavelmente desvanecendo junto com ele. E o universal, por sua vez, é essencial, porque nele todas as diferenças encontram como essência um princípio simples, em que podem sustentar-se. Sua tarefa, então, é encontrar o ser em relação ao qual não há diferença. Dessa forma, quando a essência for encontrada sob formas opostas, a consciência saberá tratar-se de um não-ser e seu perceber será considerado ilusório. 


\section{AS EXPERIÊNCIAS DA PERCEPÇÃO}

Nesta segunda seção, serão expostas as experiências da percepção, enquanto desdobramentos do que está dado em sua estrutura. A consciência busca a verdade como o igual a si mesmo, ou seja, como unidade, já que o universal surgiu da certeza sensível como o que permanece o mesmo pelo desvanecer da multiplicidade dos elementos singulares. Entretanto, a percepção concebe esse universal ainda de modo condicionado, na medida em que não se dá conta que a diferença, a multiplicidade, o determina essencialmente.

\subsection{A primeira experiência: a tensão entre unidade e multiplicidade}

Uma vez descritos o objeto e o saber da percepção, Hegel expõe a experiência pela qual passa essa figura da consciência. Inicialmente, o filósofo afirma o seguinte:

\footnotetext{
O objeto que eu apreendo apresenta-se como puramente Uno; também me certifico da propriedade que há nele, que é universal mas que por isso ultrapassa a singularidade. O primeiro ser da essência objetiva como um Uno não era pois seu verdadeiro ser. Como o objeto é o verdadeiro, a inverdade recai em mim: o apreender é que não era correto. Devido à universalidade da propriedade, devo tomar a essência objetiva antes como uma comunidade em geral (FE, p. 87, § 117).
}

A consciência inicia tomando o objeto como o uno. Com se viu, nesta situação, as propriedades estão relacionadas entre si de modo excludente, pois é assim que elas se determinam e, consequentemente, estabelecem a especificidade da coisa a que pertencem. Por essa relação, cada propriedade fica determinada como propriedade de uma coisa específica. Entretanto, as propriedades que estão nessa coisa não existem apenas dela. Podem estar presentes também em outros objetos, são universais elas mesmas. Mas, se elas estivessem num uno excludente, o ser de cada uma seria determinado pela relação negativa a que elas se submetem aí. Logo, seu ser não poderia ir além do âmbito dessa unidade. Como a propriedade vai além dessa singularidade, já aparece uma primeira desigualdade na percepção do objeto. Mas o objeto é igual a si mesmo. Assim, ele deve ser uma comunidade em geral em que todas as propriedades estão presentes. A primeira percepção é falsa e deve ser considerada uma determinação do sujeito percebente.

Mas, por outro lado, as propriedades não podem estar numa comunidade em geral, pois são determinadas e, consequentemente, relacionam-se entre si através da negação. A mútua negação implica que a coisa que constituem é antes um uno excludente. Entretanto, as propriedades estão em cada coisa como propriedades isoladas, indiferentes umas às outras. Cada propriedade está exatamente onde outras estão: na mesma coisa. Uma não interfere no ser da outra e, ao mesmo tempo, cada uma é determinada como uma propriedade específica 
do objeto. Assim, o objeto também não pode ser um uno excludente, nem manter relações puramente negativas com outras propriedades. Essa exigência só pode ser cumprida se a propriedade for considerada uma universalidade sensível independente, que exclui de si as outras enquanto determinada em si mesma. Ou seja, diante do fato de várias propriedades coexistirem numa mesma coisa e serem ao mesmo tempo determinadas, elas têm de ser tratadas como essências autossuficientes. E assim o objeto deve ser considerado um meio comum universal.

Entretanto, segundo a exposição hegeliana, essa nova forma de encarar a objetividade acaba trazendo outros problemas.

[...] sendo assim, o simples e verdadeiro que eu percebo não é um meio universal, e sim a propriedade singular para si. Porém a propriedade desse modo nem é propriedade nem um ser determinado, pois não está nem em um Uno, nem em relação com outras. No entanto, somente é propriedade em um Uno, e só é determinada em relação às outras. Permanece esse puro relacionar-se-consigo-mesma, apenas Ser sensível em geral, pois já não tem em si o caráter de negatividade (FE, p. 87, § 117).

Um elemento só é propriedade na medida em que está presente num certo objeto, quer dizer, numa certa unidade. Da mesma forma, pelo fato de ser determinado, esse elemento distingue-se de todos os demais ou, como afirma Hegel, nega-os. Entretanto, por serem universais, as propriedades deveriam ser indiferentes entre si. A coisa, portanto, deveria ser um meio indiferente. Por outro lado, como são determinadas, essas propriedades negam-se mutuamente. A solução é concebê-las como entes isoladamente determinados. Por esse recurso, a determinidade e a universalidade das propriedades são garantidas. Entretanto, com isso o que é posto como essência não é a propriedade como tal, mas antes um ser sensível simplesmente indicado. Isso porque, não estando em relação com outras, não é determinada e, não sendo parte de uma unidade, não pode ser considerada uma propriedade.

\subsection{O desvanecer do perceber e a descoberta do engano}

Segundo Hegel, a impossibilidade de manter a coisa seja como uno excludente seja como meio indiferente faz a percepção retornar à certeza sensível, tentando apanhar a propriedade como ente singular. Mas, do intuir ela deve voltar ao perceber, pois, como se mostrou no capítulo anterior, o sensível imediato não pode ser a verdade buscada pela consciência. Resta à consciência, então, um desvanecer tanto da singularidade visada, quanto da universalidade tomada como propriedade.

Para Hegel, isso significa que a consciência "fez, justamente, sobre o perceber a experiência de que o resultado e o verdadeiro dele - é sua dissolução ou a reflexão sobre si mesma, a partir do verdadeiro" (FE, p. 88, § 118). Quer dizer, a consciência, a partir do perceber, é lançada à sua própria dissolução seguindo exatamente o que é para ela verdade. Ela sabe agora que não se apossa do verdadeiro enquanto percebe, já que seu objeto se dissolve justamente quando tomado naquilo que deveria ser sua própria essência. Mas o objeto, na sua igualdade consigo mesmo, é a essência, por isso não pode produzir sua própria destruição. Então, é preciso admitir que o perceber não é a simples apreensão de um 
conteúdo objetivo. Nele deve estar implicada também a consciência, como o elemento que faz com que o objeto entre em colapso.

Segundo Hegel, essa descoberta não é simplesmente negativa. O que permanece não é apenas o eterno retorno da consciência ao ponto de partida. A evidência de que esse movimento é inevitável significa para ela também um avanço. Por esse caminho, "[...] ficou determinado para a consciência como é que seu objeto está constituído, isto é: seu objeto não consiste em ser um puro apreender simples, mas em ser seu apreender ao mesmo tempo refletido em si a partir do verdadeiro" (FE, p. 88, § 118). A consciência descobre, portanto, que em seu apreender não está em jogo apenas o objeto como tal, mas também ela mesma. Em outras palavras, ela sabe agora que no apreender ela mesma está presente a partir do modo como toma o verdadeiro. Consequentemente, o próprio verdadeiro é mudado. Agora a consciência sabe que tem sempre de retirar do objeto a parte que ela mesma acrescentou, resgatando assim sua pureza. É justamente essa nova consideração que a faz retomar, sob novo ponto de vista, a verdade.

O ganho com a experiência até aqui exposta está no fato de que agora "a consciência [...] através desse reconhecimento é capaz, ao mesmo tempo, de suprassumir essa inverdade: distingue seu apreender do verdadeiro, da inverdade de seu perceber; corrige-o". Ou então, ela "[...] já não percebe simplesmente; senão que também é cônscia de sua reflexão-sobre-si, e a separa da simples apreensão" (FE, p. 88, § 118). Devido à descoberta, por parte da consciência, de que ela interfere na verdade, ela assume como tarefa levar em conta no aprender, além do objeto, o que é acréscimo seu. Como a parte que the cabe é causa de erros, deve ser retirada do conhecimento finalmente constituído para que o objeto possa ser alcançado na sua pureza.

\subsection{A segunda experiência: a tensão entre o perceber e a coisa}

A partir dessas novas diretrizes, a consciência experimenta mais uma vez seu objeto. Inicialmente, toma-o como uno. As várias propriedades que aparecem imediatamente são, na verdade, frutos da reflexão da consciência. Assim, "[...] essa coisa é branca só para nossos olhos, e também tem gosto salgado para nossa língua, é também cúbica para nosso tato etc. Toda a diversidade desses aspectos, não tomamos da coisa, mas de nós. [...] Somos assim o meio universal onde esses momentos se separam e são para si” (FE, p. 88, § 119). A coisa é mantida na sua igualdade consigo mesma, enquanto uno, pela atribuição da diferença, a existência de múltiplas propriedades, à própria consciência. As propriedades, portanto, devem ser tratadas como construções do aparelho perceptivo, que por isso mesmo não podem ser misturadas à consideração do objeto em-si.

"Mas (argumenta Hegel), esses diversos aspectos que a consciência assume são determinados - se considerados cada um para si como no meio universal se encontram. $O$ branco só é em oposição ao preto etc.; e a coisa só é Uno justamente porque se opõe às outras" (FE, p. 89, § 120). Isso significa que a coisa tem de ser não apenas um uno, mas também um meio universal de muitas propriedades. Em primeiro lugar, cada propriedade só é determinada ao opor-se às demais. Isso significa que a coisa deve ser tratada como um meio em que uma multidão de propriedades estabelece entre si relações de negação. Em segundo 
lugar, a coisa só é uma unidade igual a si mesma ao diferenciar-se de outras coisas. Isso só é possível na forma de oposição: a coisa tem de "não ser" as demais. Para isso, é necessário que ela contenha em si elementos que possam determiná-la. Essa determinação interna, entretanto, só é possível na medida em que a coisa tem propriedades que estabeleçam sua especificidade. As propriedades, por isso, têm de ser da própria coisa e não simplesmente do perceber. Logo, "a coisa é o também, o meio universal, no qual as propriedades subsistem, fora uma da outra, sem se tocarem e sem se suprassumirem" (FE, p. 89, § 120).

Se a coisa é o meio universal, deve-se inverter a relação entre ela e a consciência. Antes a coisa era o uno e o perceber assumia para si a multiplicidade. Agora essa multiplicidade é posta na própria coisa. Consequentemente, a unidade tem de ser considerada um efeito do próprio perceber. Assim, enquanto a coisa é a "superfície envolvente" das diversas propriedades ou "matérias livres" (FE, p. 89, § 121), a consciência é o uno. Entretanto, a exigência da unidade também pertence à coisa, como já se mostrou. Com isso, segundo Hegel,

\begin{abstract}
reexaminando o que a consciência antes assumia e o que assume agora, [...] ressalta que a consciência faz, alternadamente, ora de si, ora da coisa, tanto o Uno puro sempluralidade, como um também dissolvido em 'matérias' independentes. A consciência acha, através dessa comparação, que não é apenas seu 'tomar do verdadeiro [perceber], que nele possui a diversidade do apreender e do retornar a si, mas antes, é o próprio verdadeiro - a coisa - que se apresenta dessa dupla maneira de ser (FE, p. $90, \S 122)$.
\end{abstract}

Ao tomar a coisa como uno, a consciência até tenta assumir como efeito seu a multiplicidade, para mantê-la igual a si mesma. Entretanto, como se viu, isso não é possível. A multiplicidade tem de ser da própria coisa. Tomando a coisa como múltipla, volta a exigência de conceber a unidade como algo referente apenas à percepção. Com isso, segundo a exposição hegeliana, o que fica explícito à consciência é o fato de a própria coisa exigir esse duplo tratamento. Quando é posta como uno, imediatamente o ser múltiplo é posto. E, ao ser tratada como superfície envolvente, a exigência da unidade reaparece. Assim, para a consciência, é a própria coisa que suscita esse duplo modo de ser. O uno e o múltiplo, por isso mesmo, não devem mais ser divididos entre a consciência e a coisa. Os dois são constituintes do próprio objeto.

Sendo assim, a própria coisa está refletida em si mesma. Ela "[...] é para si, mas também é para um Outro. Na verdade, é um outro para si, como o é para um Outro" (FE, p. $90, \S 123)$. Nas experiências anteriores, quando a coisa era tomada como una, por exemplo, a multiplicidade acabava sendo um outro ser, cuja base deveria estar não nela mesma, mas na consciência. Da mesma forma, tomando a coisa como múltipla, a unidade era atribuída ao perceber. Isso significa que se fazia aí uma diferença entre a coisa mesma e o modo como ela se apresentava à consciência. O ser próprio da coisa era, na terminologia hegeliana, seu "ser para si". Mas o modo como esse ser aparecia à consciência tinha de ser tratado como seu "ser para outro". 


\subsection{0 desvanecer do "enquanto" da consciência}

A separação entre "ser para si" e "ser para outro" era realizada pelo "enquanto" da consciência. Isto é, a coisa era múltipla, por exemplo, somente "enquanto" objeto da consciência, pois, "enquanto" ela mesma, deveria ser tomada como una. Pelas experiências realizadas, esse "enquanto" mostrou ser ilegítimo, pois a coisa mesma, a partir de sua própria constituição, exige a presença dos dois aspectos - a unidade e a multiplicidade. Não é mais possível separar o "ser para si" do "ser para outro". Ambos devem estar na coisa mesma.

Com isso, a coisa está agora refletida sobre si mesma. Essa afirmação pode ser entendida a partir da compreensão daquilo que ocorre na reflexão enquanto ato mental. Quem reflete, toma um conteúdo já disponível na consciência como objeto. Por isso, o objeto nada mais é do que a própria mente. Então, a diferença entre mente e o objeto acaba sendo uma diferença da mente consigo mesma. Quer dizer, a mente é, simultaneamente, ela mesma, enquanto realizadora do ato de reflexão, e um outro ser, enquanto objeto desse ato. $\mathrm{Na}$ reflexão, portanto, a mente é tanto a igualdade consigo mesma, quanto a diferença, posta na forma de objeto.

Essa é, analogamente, a situação da coisa da percepção a esta altura. A coisa é tanto ela mesma, enquanto unidade ou multiplicidade, quanto o que surge como diferença em relação àquilo que é posto como a sua forma essencial de ser. Enquanto una, a multiplicidade deveria ser uma outra essência. Mas, ela mesma tem de assumir também esse aspecto. $E$ isso ocorre da mesma forma na situação inversa. Ela é, portanto, refletida em si: tem no seu ser tanto a igualdade consigo mesma, quanto a diferença.

Entretanto, na percepção, como se mostrou no final da primeira parte deste capítulo, a diferença está presente como algo inessencial. Na certeza sensível, o aqui como casa, por exemplo, desvanece, pois ao seu lado surge um aqui como árvore, igualmente essencial. Essa situação se repete aqui: a coisa é posta como uno, por exemplo, mas deve também ser um múltiplo. Para a consciência, isso significa que a coisa não pode ser mantida na sua essencialidade se for concebida mediante essa diferença interna. É necessário apanhá-la na sua simplicidade, ou seja, na sua igualdade consigo mesma. Isso entra em conflito com a ideia de que ela é a unidade entre a multiplicidade e o ser uno. Como consequência, só resta à consciência afirmar que, "[...] já que os dois diferem, não [incidem] na mesma coisa, e sim, em coisas diversas" (FE, p. 90, § 123). Ou seja, a igualdade consigo mesma da coisa é preservada separando o que a coisa é enquanto tal daquilo que é a diferença em relação a este ser. Ao considerar uma coisa, deve-se fazê-la assumir apenas seu ser simples, igual a si mesmo. A diferença deve ser atribuída às outras coisas.

\subsection{A terceira experiência: o "enquanto" das coisas diversas}

Essa nova maneira de conceber a objetividade apresenta-se da seguinte maneira. Conforme afirma Hegel, "[...] cada coisa se determina como sendo ela mesma algo diferente, e tem nela a distinção essencial em relação às outras; mas ao mesmo tempo não tem em si essa diferença, de modo que fosse uma oposição nela mesma" (FE, p. 91, § 124). A coisa poderia ser considerada simplesmente como uma unidade. Entretanto, é necessário que ela 
se distinga de tudo mais. Para isso, ela precisa dispor de propriedades determinadas. Assim, a coisa tem de ser considerada também um múltiplo de propriedades entre si negativas. Mas esse duplo modo de ser, que tem de estar presente na objetividade, não pode pertencer à mesma coisa. A solução é tomar a coisa enquanto tal como uma unidade e considerar a multiplicidade uma essência diferente e oposta, referente apenas ao momento em que a coisa se distingue das demais.

Para Hegel, "a coisa tem por isso, na sua unidade, o duplo enquanto, mas com desigual valor; pelo que esse ser-oposto não se torna assim oposição efetiva da própria coisa" (FE, p. 91, § 124). A multiplicidade é outra essência em relação à unidade da coisa, mas é também assumida por ela; embora não como um elemento da própria essência, pois isso entraria em contradição com o fato de a coisa ser una. A multiplicidade é, para a essência una, o momento em que ela se distingue de tudo mais. Assim, a coisa é, ao mesmo tempo, una e múltipla. Enquanto tal, quer dizer, essencialmente, é apenas una. Mas, no momento em que essa essência se diferencia da essência das demais coisas, torna-se também múltipla. Assim, a multiplicidade não é a essência da coisa. Mas está necessariamente presente na medida em que a coisa é algo determinado.

Mas, o que parecia ser a solução do problema mostra-se na verdade como o alargamento radical do paradoxo em que está envolvida a percepção. Observe-se a exposição hegeliana:

\footnotetext{
Agora essa determinidade - que constitui o caráter essencial da coisa, e a diferencia de todas as demais - se determina assim: por ela a coisa está em oposição às outras, mas nessa oposição deve manter-se para si. Porém somente é coisa - ou Uno para si essente - enquanto não está nessa relação com as outras, pois nessa relação o que se põe é antes a conexão com o Outro; e a conexão com Outro é o cessar do ser-parasi. Mediante o caráter absoluto, justamente, e de sua oposição, ela se relaciona com outras, e, essencialmente, é só esse relacionar-se. A relação porém é a negação de sua independência, e a coisa antes desmorona através de sua propriedade essencial (FE, p. 91, § 125).
}

O propósito de separar a unidade e a multiplicidade entre coisas diversas visava conservar a coisa na sua igualdade consigo mesma. Enquanto tal, a coisa deveria manter-se como una. A multiplicidade seria um momento secundário, em que a coisa distingue-se das demais. A determinação essencial da coisa, consequentemente, consistia em que ela deveria manter-se, diante das demais, no seu exclusivo relacionamento consigo mesma. Isso significa, conforme mostrou Hegel, que na verdade a coisa nada mais é do que sua relação com as outras, pois sua essência é, antes de tudo, um modo determinado de ela relacionar-se com aquilo que lhe é oposto. Em outras palavras, o que a percepção tenta pôr como essência da coisa é seu relacionamento consigo mesma. Entretanto, nisso mesmo o que é posto é o contrário, pois o que se relaciona consigo mesmo é o que exclui de si o outro e a exclusão é um modo determinado de relação. Portanto, a coisa, como afirma Hegel, desmorona justamente a partir daquilo que deveria ser sua essência.

$\mathrm{Na}$ verdade, essa consideração poderia ter sido feita, segundo Hegel, a partir da própria caracterização da coisa. Ela é essencialmente a pura igualdade consigo mesma. Mas é também, secundariamente, um ser múltiplo. Embora inessencial, esta segunda característica da coisa lhe é necessária, pois expressa o fato de a coisa ser um ente determinado, distinto 
dos demais. "Contudo - segundo Hegel - essa é uma distinção que só reside nas palavras: o inessencial que ao mesmo tempo deve ser necessário suprassume a si mesmo" (FE, p. 92, §127). Se a coisa é necessariamente múltipla, então não é possível considerar a multiplicidade algo inessencial a ela. Aí já está posto que a coisa tem de assumir, como sua essência, os dois aspectos: a unidade e a multiplicidade.

Com isso, "[...] fica descartado o último enquanto, que separava o ser-para-si e o serpara-Outro. O objeto é, antes, sob o mesmo e único ponto de vista, o oposto de si mesmo" (FE, p. 92, § 128). Desde o início, a percepção viu duas características surgirem como essenciais à coisa: a unidade e a multiplicidade. Mas a coisa, enquanto universalidade, deveria ser a suprassunção de toda diferença. Isso significa que ela não poderia ser um oposto. Deveria manter-se como algo simples, igual a si mesmo. Como a consciência verificou na experiência da certeza sensível, opostos igualmente essenciais desvanecem. Para manter a coisa na sua igualdade consigo mesma e evitar esse desvanecer, a percepção tomou por tarefa separar os momentos da multiplicidade e da unidade. Primeiro usou o "enquanto" da consciência, em que o elemento tomado como oposto à essencialidade da coisa deveria ser assumido pela consciência. Assim, por exemplo, a coisa seria múltipla apenas "enquanto" percebida. Ela mesma, porém, deveria ser una. Pelas razões já apresentadas, esse artifício mostrou ser inviável. A outra tentativa foi separar os dois elementos entre coisas diversas. Nesse caso, a coisa seria múltipla apenas "enquanto" oposta à outra. Mas, essencialmente seria una. Como se mostrou, também esse ponto de vista não pôde ser aceito. Assim, todos os "enquanto" da consciência mostraram ser ineficazes. Todas as tentativas de tomar a coisa como uma igualdade simples ("ser-para-si"), tornando o que é diverso a esta unidade ("serpara-outro") uma essência oposta, fracassaram, restando à consciência a conclusão inevitável de que a coisa é, segundo sua essência, a unidade entre a igualdade consigo mesma e a diferença.

\subsection{O universal incondicionado como a verdade da percepção}

É importante observar que ocorre na percepção, assim como se verificou na certeza sensível, uma passagem da conclusão negativa a respeito do saber para uma nova forma de tomar a objetividade. A consciência achava que a verdade deveria ser, acima de tudo, a coisa na sua igualdade consigo mesma. Entretanto, por mais que tentasse resguardar esse princípio, a coisa mostrou ter a diferença inserida em sua essencialidade. Aparentemente, isso significa apenas que a consciência descobriu que estava enganada a respeito da verdade. Entretanto, junto com isso constituiu-se também um novo saber e, consequentemente, uma nova verdade. A coisa é a unidade entre o ser para si e o ser para outro, ou seja, entre a igualdade consigo mesma e a diferença.

Aliás, a essa nova forma de tomar a objetividade, Hegel dará o nome de universal incondicionado. Isso está ligado aos elementos que entraram em jogo na sua constituição, a partir das experiências da consciência. Para Hegel, os problemas que a percepção teve em relação a seu objeto tiveram origem no fato de que a universalidade, princípio a partir do qual ele foi considerado, esteve condicionada pelo sensível. Por isso, o universal não pôde ser tratado efetivamente como o igual a si mesmo, na medida em que o sensível, presente nele, 
sempre trazia consigo a diferença, que se expressava da distinção entre uno e múltiplo. Com a experiência desenvolvida, a consciência descobriu que o ser para si e o ser para outro estão numa unidade na coisa. E, "[...] já que ambos estão essencialmente em uma unidade, assim está presente agora a unidade absoluta incondicionada" (FE, p. 92, § 129). O universal surgiu como o que reúne em si as diferenças evanescentes da certeza sensível. Consequentemente, ele foi determinado como o que suprassume toda diferença e, portanto, não tem nenhum elemento como diferente de si. Mas, especialmente conforme o resultado da última experiência da percepção, essa determinação é antes o oposto do que pretende ser. Aquilo que é determinado como o que não se relaciona com mais nada é antes apenas essa relação. O universal da percepção, assim, desvanece justamente naquilo que deveria ser sua base. Esse desvanecer, como se pode ver, ocorre porque o universal da percepção pretende ser a negação radical da diferença e, nisso mesmo, torna-se o vínculo necessário com ela. Se o universal só existe enquanto nega a diferença, então a diferença é condição de sua essencialidade. Por isso é que o universal da percepção é condicionado. $O$ universal que surge como resultado das experiências dessa figura da consciência, por sua vez, é incondicionado, pois ele assume a diferença como parte de si mesmo. A condição, portanto, passa de externa a interna. Ora, o que tem a si mesmo como condição é incondicionado. Assim, a nova verdade da consciência deve ser o universal incondicionado. 
CAPÍTULO IV

A AUTOCRÍTICA DO ENTENDIMENTO 


\section{A ESTRUTURA DO ENTENDIMENTO}

Neste quarto capítulo, apresentar-se-á a terceira e última figura da seção "consciência" da Fenomenologia do espírito: o entendimento. Verificar-se-á como se determinam os elementos do entendimento e as experiências que ele desenvolve a partir deles. A tensão entre unidade e multiplicidade, resultado da dialética da percepção, está presente aqui, revelando-se das mais variadas formas. Apenas superando a forma limitada de conceber essa relação o entendimento poderá realizar seu objetivo de alcançar a verdade. Mas, para isso, terá também descobrir-se enquanto autoconsciência.

Nesta primeira seção, apresentar-se-á as determinações fundamentais do entendimento, engendradas a partir dos resultados das experiências da percepção.

\subsection{0 significado das experiências da certeza sensível e da percepção}

A figura do entendimento, como um modo específico de a consciência tomar a si mesma e ao objeto de seu saber, surge quando é ultrapassado o estágio do simples perceber. Essa passagem, por sua vez, é necessária na medida em que se evidenciam os paradoxos a que a consciência está submetida quando toma seu objeto como um universal percebido. $O$ novo objeto, que ao ser concebido inaugura a figura do entendimento, estrutura-se justamente a partir dos paradoxos da figura anterior, no caso a percepção. Assim, para expor o que é o entendimento, é preciso mostrar como seu objeto surgiu a partir da experiência desenvolvida na percepção.

A percepção parte do ponto de vista segundo o qual o princípio básico da objetividade é a universalidade, que foi expressa na forma de coisa de muitas propriedades. Enquanto simplesmente universal, a coisa foi tomada como um coexistir de propriedades indiferentes. Todas deveriam estar no mesmo meio, sem que uma interferisse na outra. Mas, por outro lado, a universalidade só poderia ser efetiva se as propriedades de que se compunha fossem determinadas, ou seja, fossem capazes de distinguir-se mutuamente. Consequentemente, por este aspecto a coisa deveria ser tomada antes como uma unidade, cujos elementos estão em oposição recíproca. É a partir desses dois aspectos, inerentes ao ser da coisa de muitas propriedades, que se desenvolveram todos os paradoxos subsequentes.

Outra consideração também é importante. Na medida em que o princípio da objetividade é a universalidade, a coisa de muitas propriedades tem de ser o simples, o igual a si mesmo, pois o universal é a unidade que suprassume todo ser outro (toda diferença). Aqui cabe lembrar a figura da certeza sensível, gênese do universal para a consciência. Nela a verdade era a pura singularidade. Entretanto, ao lado de cada singular (esta casa, o dia etc.) sempre surgia outro ser também singular, e, portanto, com o mesmo direito de ser a verdade. 
Mas, pelo fato de serem entes diferentes, cada um não era o outro, isto é, cada um era a negação do outro. Logo, se um fosse tomado como a verdade (agora é dia, por exemplo), o outro deveria ser falso (agora não é noite, por exemplo). Entretanto, como se disse, por serem ambos singulares, os dois respondiam perfeitamente ao critério de verdade. Consequentemente, o que ficou evidenciado foi antes a falsidade do próprio critério de verdade, a singularidade. O singular não é verdadeiro, pois é sempre um não ser. Ou, dizendo de outra forma, a singularidade é verdade enquanto algo não verdadeiro, algo que não é (ser evanescente). A diferença ou o ser outro é o que faz de cada singular um não ser. Então a verdade é o singular evanescente como evanescente, ou seja, a universalidade. Mediante a negação de cada singular, alcança-se o universal como o verdadeiro. Mas o universal só é o verdadeiro porque reúne em si todo ser singular e, portanto, todo ser outro (toda diferença). Então, a diferença está no universal, mas como algo que não é. E, por seu não ser, o que é posto como essencialidade é a igualdade consigo mesma ou a simplicidade do universal. Assim, a coisa tem de ser buscada como meio de propriedades indiferentes e como unidade em que essas múltiplas propriedades se excluem. Mas em tudo isso tem de ressaltar sua igualdade consigo mesma, pois a diferença é um não ser.

A percepção tomou inicialmente seu objeto como uma unidade. Entretanto, o objeto só poderia ser universal se nele houvessem múltiplas propriedades simplesmente coexistindo. Então, tentou considerá-lo como a comunidade dessas propriedades. Mas as propriedades deveriam ser determinadas para que o universal pudesse ser uma essência efetiva. Isso significou para a consciência que ele deveria ser tomado como uma unidade em que as múltiplas propriedades excluem-se mutuamente. Contudo, ainda era necessário que as propriedades estivessem enquanto tais num meio único (a simplicidade do universal). Por isso, não restou à percepção outra opção a não ser conciliar a indiferença entre as propriedades com o fato de elas serem determinadas. Mas, sendo indiferentes não seriam determinadas e excluindo-se mutuamente (cada uma não sendo a outra - momento da determinação) não estariam na simplicidade do universal. Consequentemente, o que resultou foi o simples ser visado da certeza sensível, que já tinha sido descoberto em sua inessencialidade.

Da inverdade da certeza sensível, a consciência foi reencaminhada ao perceber e à sua verdade - o universal. Assim, a consciência sabia que não poderia permanecer na certeza sensível e, consequentemente, que o universal era a verdade. Mas ela sabia também que, ao ser percebido, ele já tinha se mostrado ilusório. Por outro lado, o objeto surgiu como o verdadeiro. Por isso, para ela se tornou evidente que a falsidade foi resultado de um ato seu, não do objeto. Então esse ato deveria ser separado da consideração da coisa mesma para alcançá-la em sua pureza. A coisa deveria ser mesmo a unidade simples. As diferentes propriedades que apareciam deveriam ser assumidas como efeitos do perceber (ver, ouvir, tocar, etc.). Entretanto, outra consideração não pôde deixar de ser feita. O próprio ser da coisa dependia de suas propriedades, isto é, elas eram as únicas determinações próprias da coisa. Consequentemente, o objeto teve de ser tratado como um meio universal de propriedades determinadas. O ser uno, entretanto, também surgiu, porque no universal a essência é a unidade simples. Para salvar a igualdade consigo mesma da coisa, o ser uno foi assumido pela consciência. Nisso a percepção se deu conta de que estava fazendo ora de si ora do objeto uma unidade simples e um meio de matérias independentes. Isso significou para ela 
que os dois momentos são necessários a partir da própria coisidade. Mas a coisa, por ser universal, tem de manter-se igual a si mesma, excluindo de si toda diferença. Os dois momentos, por conseguinte, embora tenham sido postos ambos na coisidade, não poderiam referir-se à mesma coisa. Assim a oposição foi distribuída em coisas diversas, de modo que a coisa poderia voltar a ser tomada como una e a multiplicidade caberia a ela apenas na medida em que se relacionasse com outras.

Entretanto, também aqui o artifício da consciência não pôde deixar de ser flagrado em sua deficiência. Era somente graças à sua diversidade interna que a coisa poderia ser determinada, de modo que ela lhe era absolutamente necessária. Então a própria coisa, enquanto una, deveria ser também múltipla.

Com isso, foi abaixo a consideração capital implicada no princípio da universalidade - a igualdade consigo mesma da coisa. O ser para si, ou a igualdade consigo mesmo, está unido ao ser para outro, ao que é diferente. O uno está necessariamente ligado a seu outro, o múltiplo. O problema é que a universalidade só é determinada através de suas múltiplas propriedades, e as múltiplas propriedades tem de estar na simplicidade do universal. Essas duas exigências opostas, intrínsecas à própria caracterização da universalidade percebida, fazem com que nela mesma sempre estejam presentes duas essências. Enquanto a consciência fixa a coisa numa delas, que passa a ser seu ser para si, a outra essência, que Ihe é necessária mas oposta, torna-se seu ser para outro. Mas devido ao modo necessário com que estão ligados na coisa, é preciso admitir que enquanto é para si também é para outro, e vice-versa. A coisa é a oposição em si mesma.

O problema é que o objeto da certeza sensível, o singular, foi descoberto em sua verdade como um não ser. Essa descoberta fez surgir a verdade como a universalidade sensível, como o singular que retorna a si mesmo, como o agora que não é este agora (dia ou noite) mas que é uma porção de agoras diversos numa unidade. Mas enquanto tomado como sensível, o universal (o agora que permanece, por exemplo) está condicionado pela singularidade. É pelos seus elementos singulares que ele é determinado como universal e que pode inclusive distinguir-se de tudo mais em sua singularidade. Consequentemente, a universalidade só é enquanto os singulares de que se constitui também são. Assim, tomando a coisa como uma unidade simples, a determinação permanece como sendo algo diferente.

Mas na medida em que a universalidade da coisa está unida ao lado de sua determinação, o que era outro tornou-se constitutivo da coisa, o ser para si é ao mesmo tempo ser para outro. Isso significa que o novo objeto assumiu para si (como sua própria essência) aquilo que antes era uma condição externa. A universalidade era o retorno a si (ao que permanece, ao essente) dos momentos singulares evanescentes e, por isso, ao mesmo tempo em que excluía de si a singularidade múltipla, dependia dela para ser uma certa coisa específica. Esta era sua condição, mas por ser excluída de si, era-lhe externa. Com a descoberta dos paradoxos que este modo de tomar a objetividade comporta, chegou-se ao ponto de tomar a verdade, o objeto do saber, como o universal incondicionado, ou seja, como um universal que assumiu em sua essência o ser para outro, a diferença, ou que tem a sua condição em si mesmo (por isso é incondicionado). 


\subsection{Os dois pontos de vista sobre o universal incondicionado}

Para Hegel, esse caráter próprio do incondicionado faz com que ele não possa ser considerado da mesma forma que a coisa da percepção. Segundo ele, "se esse incondicionado fosse agora tomado por essência inerte e simples, nesse caso não seria outra coisa que o extremo do ser-para-si, posto de um lado; em confronto como ele se colocaria a inessência; mas nessa relação à inessência seria também ele inessencial” (FE, p. 95, § 132). O objeto do entendimento, na medida em que é o universal incondicionado, não pode ser tratado como uma essência inerte e simples. Uma essência inerte, como se pode deduzir de seu conceito, é aquela que não muda. Na mudança está implicada a diferença: algo só muda quando se torna, de algum modo, diferente do que é. Então, por essência inerte Hegel está entendendo a essência que permanece sempre igual (igual a si mesma) ou que não admite o movimento de tornar-se outro (ser diferente de si). Da mesma forma, a simplicidade de uma essência está ligada ao fato de ela não ser resultante da composição de partes diferentes entre si, ou seja, de ela não ter em si nenhuma diferença. Isso significa basicamente que numa essência inerte e simples a diferença não pode estar presente.

$\mathrm{Na}$ verdade é isso que Hegel quer destacar quando afirma que uma essência inerte e simples seria o extremo do ser para si. Como se viu, na percepção tornou-se evidente já para a consciência que, ao lado da universalidade simples, igual a si mesma, acaba sempre surgindo a diferença. Como a coisa, sob o princípio da universalidade, era tomada como igual a si mesma, a diferença só poderia ser posta como algo inessencial. Entretanto, pelo caráter necessário da presença da diferença em relação ao ser para si (igual a si mesmo), que deveria ser o único elemento essencial, o próprio ser para si se torna tão inessencial quanto o que ele põe como inessencial. Isso porque justamente com essa ligação necessária entre eles fica evidenciada a dependência de um para com o outro. Ora, o incondicionado na verdade surgiu para expressar exatamente essa realidade: a unidade entre o ser para si e o ser para outro. Por isso não pode novamente reduzir-se ao extremo do ser para si, da essencialidade inerte e simples, da coisa igual a si mesma que exclui de si a diferença. Como ver-se-á na sequência, os problemas fundamentais do entendimento estarão ligados a essa necessidade de inserir no interior da essência, como fator decisivo, a diferença ou a mudança.

Outro aspecto importante em relação ao universal incondicionado é o seu caráter objetivo em relação ao entendimento. Como afirma Hegel, o incondicionado

[...] ainda está como objeto dessa consciência - a qual ainda não apreendeu o conceito como conceito. [...] Para a consciência, o objeto retornou a si mesmo a partir da relação para com um outro, e com isso tornou em-si conceito. Porém a consciência não é ainda, para si mesma, o conceito; e por causa disso não se reconhece naquele objeto refletido (FE, p. 95, § 132).

Antes de mais nada, é importante destacar a tensão que há, no trecho acima, entre o modo como o objeto é caracterizado por Hegel e o modo como a consciência o concebe. Para Hegel, por ele ser a volta a si a partir do outro, é conceito. Mas essa consideração só é possível a quem já chegou ao final do processo dialético da Fenomenologia do espírito e pode, com isso, conhecer, nos seus aspectos essenciais, cada momento do que ocorre nele. Esse é o caso de Hegel, mas não é o caso da consciência enquanto entendimento. A 
consideração mais verdadeira é a do filósofo, que, entretanto, não pode ser completamente justificada nesse ponto (na figura do entendimento) porque supõe exatamente a sua ultrapassagem. Assim, a consideração do filósofo, afirmando que o objeto do entendimento é, na verdade (em si) conceito, pois retornou a si a partir da relação para com outro, deve ser tomada como uma antecipação ainda carente de justificação, mas que vai mostrar-se verdadeira com o decorrer do processo.

De todo modo, o que Hegel quer mostrar aqui é o modo próprio de o entendimento considerar o universal incondicionado a partir da forma como ele surgiu para ele. $\mathrm{Na}$ percepção, a consciência tinha por conteúdo de seu saber, segundo sua própria consideração, apenas a objetividade sensível. Por isso, o movimento segundo o qual o incondicionado surgiu como verdade para ela refere-se apenas ao que é objetivo e não a ela mesma. Essa afirmação tem importância na medida em que deixa expresso o fato de que o entendimento vai tentar considerar seu objeto como algo objetivo ou, em outras palavras, vai tentar distinguilo de si mesmo.

Como o incondicionado é para o entendimento algo puramente objetivo, este "[...] simplesmente o contempla e puramente o apreende" (FE, p. 96, § 133). Em outras palavras, se para o entendimento a verdade está fundada objetivamente, resta-lhe como prerrogativa manter um comportamento puramente passivo em relação a ela. Qualquer influência sobre a verdade só poderia significar distorcê-la, nesse contexto. Devido a essa situação, Hegel faz a seguinte observação a respeito da sequência da exposição fenomenológica. Observe-se a argumentação seguinte.

\footnotetext{
Nós devemos por isso, antes de mais nada, pôr-nos em seu lugar e ser o conceito que modela o que está contido no resultado: somente nesse resultado completamente modelado - que se apresenta à consciência como um essente - ela se torna para si mesma consciência concebente (FE, p. 96, § 133).
}

A argumentação de Hegel tenta mostrar em que ponto de vista é preciso pôr-se para descrever o processo pelo qual a verdade vem a ser para a consciência o conceito. $O$ entendimento toma a verdade como uma essência dada. Sua postura é, consequentemente, a da consciência que simplesmente contempla o objeto que lhe é oposto. A verdade é situada fora da consciência, de modo que a subjetividade tem de ser repelida dela. Mas o incondicionado é em si conceito, como Hegel já antecipou. Ele é, assim, o modo pelo qual o conceito se manifestou à consciência. É preciso ver, então, como o entendimento, a partir do aparecer do conceito, chegou à sua essência e o tomou como conceito. Isso significa que para descrever o processo é preciso já tomar o ponto de vista de sua conclusão, pois é só nesse nível que se sabe que há algum processo a ser descrito. Com isso também se pode dizer que é preciso assumir o ponto de vista do conceito que está se revelando como verdade no processo mesmo.

Aliás, é importante destacar essa ideia para que o trecho mencionado não seja mal interpretado. Aparentemente, Hegel está dizendo que é preciso ser o conceito que modela (ausbildung) o incondicionado até que a verdade deixe de ser apenas uma essência a ser contemplada e a consciência possa ser para si mesma consciência concebente, ou seja, uma consciência para quem a verdade é o conceito. Poder-se-ia concluir daí que o próprio processo de desenvolvimento só é possível pela ação (o modelar) da consciência filosófica 
sobre o objeto do entendimento. Assim, de algum modo ter-se-ia de tomar o incondicionado e demonstrar que ele só é verdade como conceito.

Entretanto, a Fenomenologia quer ser a descrição do desenvolvimento autônomo da consciência, que a partir do modo mais ingênuo de tomar a verdade elevou-se ao saber pleno. Nesse processo, a consciência não poderia tomar como apoio verdade alguma além daquela que ela mesma dispunha. Por isso, não cabe ao filósofo ensinar a consciência a pensar, mas apenas acompanhar seu próprio desenvolvimento. Então, o que Hegel quer dizer é que, quando se descreve o processo de autodesenvolvimento do entendimento, na medida em que se assume o ponto de vista de seu final, como já foi dito, está-se na verdade assumindo a posição do conceito que modela o incondicionado até ele se tornar para si conceito (assumindo a forma plena de conceito). Ou seja, ao assumir o ponto de vista do final do processo, na medida em que ele nada mais é do que a expressão da verdade já contida no ponto de partida e na medida em que o próprio processo nada mais é do que o fruto do autodesenvolvimento do ponto final, está-se assumindo o ponto de vista do conceito que modela o ponto de partida (o incondicionado) para revelar o que é em si. Isso significa que Hegel não quer expor para o entendimento o fato de que o incondicionado é na verdade conceito. Ele quer antes mostrar como o próprio entendimento chegou à conclusão segundo a qual o que ele tomava como verdade no incondicionado já era o conceito. Para isso ele tem de buscar no entendimento a ação (o modelar) do conceito sobre o incondicionado; e isso significa acompanhar o conceito no seu autodesenvolvimento ou, nas palavras de Hegel transcritas acima, "ser o conceito que modela o que está contido no resultado" [o incondicionado].

\subsection{As determinações do universal incondicionado}

O incondicionado, segundo Hegel, surgiu "[...] de início no sentido negativo e abstrato, de que a consciência negava seus conceitos unilaterais e os abstraía; e, a bem dizer, os abandonava" (FE, p. 96, § 134). Na percepção, o objeto era tomado ora como meio universal de matérias livres, ora como unidade exclusiva. E quando era tomado num desses momentos, o outro era excluído de sua consideração. Se o objeto fosse, por exemplo, o uno, a multiplicidade deveria ser, de algum modo, excluída da coisa. Como indica Hegel, pela experiência da percepção, a consciência descobriu inicialmente que ao se tomar a coisa a partir apenas de um de seus momentos ela era levada a considerá-lo um evanescente, pois ele mostrava depender necessariamente do outro. $O$ uno só era determinado se tivesse em si propriedades diversas, e assim a coisa mostrava-se antes como meio universal dessas matérias. Da mesma forma, a multiplicidade de propriedades não era nada além da própria coisa, e a consciência voltava a considerá-la como uma unidade. Ou seja, cada momento, tomado isoladamente como essência da coisa, desvanecia (negação) e era abandonado.

No fundo, a consciência queria a coisa em seu ser para si (em sua igualdade consigo mesma), que era considerado ora a unidade, ora a multiplicidade. E cada um desses momentos desvanecia diante do que era posto como outra essência (ser para outro, diferença), e por isso tinha de ser abandonado. Tratada assim, a descoberta da percepção tem um sentido, por um lado, negativo, pois permanece na negação de cada momento como 
essência da coisa; e, por outro, abstrato, pois considera cada momento apenas isoladamente, pondo um como ser e outro como não ser, sem considerar que no fundo é só pela unidade entre ambos que o movimento entre eles tem origem. Aliás, esse é o sentido principal do resultado da experiência da percepção, como o próprio Hegel sublinha. Para ele, "[...] o resultado tem em si a significação positiva de que nele está posta imediatamente, como a mesma essência, a unidade do ser-para-si e do ser-para-outro, ou a oposição absoluta" (FE, p. 96, § 134). A conclusão meramente negativa e abstrata tem em si já um significado positivo. A percepção queria a coisa como o igual a si mesmo que exclui de si a diferença. Entretanto, ao lado do ser para si surgia sempre o ser para outro. Inicialmente isso significou para a consciência apenas a perda de sua verdade. Esse é o significado negativo e abstrato. Toda vez que ela pensava ter-se apossado da coisa com tal, surgia também seu oposto e a coisa assim como tinha sido tomada desvanecia. O que Hegel quer salientar é que isso tem também um significado positivo. Se o ser para si não pode permanecer à parte do ser para outro, então a verdade é que eles estão unidos e essa tem de ser a nova essência da objetividade. Aliás, é só levando isso em conta que a conclusão anterior da consciência é considerada negativa e abstrata. Primeiro a consciência se dá conta de que não pode manter dissociados os dois momentos da coisa (o ser para si e o ser para outro). Então, a essência da coisa deve estar na unidade entre eles. E se a essência é a unidade, a conclusão anterior era negativa, pois só considerava o não ser, e no fundo abstrata, pois o não ser só era objeto da consciência, naquele momento, porque ela considerava os momentos, que essencialmente são unidos (segundo sua descoberta ulterior), de modo dissociado. Ou seja, o universal incondicionado (a unidade entre o ser para si e o ser para outro) já era objeto da consciência, mas ela o cindia (abstração) em ser para si e ser para outro; alcançando, consequentemente, apenas o desvanecer de momentos abstratos.

Assim, a característica básica do universal incondicionado é ser a unidade entre o ser para si e o ser para outro. Segundo Hegel, "à primeira vista, parece que isso concerte só a forma dos momentos, um em relação ao outro; porém o ser para si e o ser para outro são também o próprio conteúdo" (FE, p. 96, § 134). Como se vê, pela hipótese que Hegel está cogitando, a unidade entre ser para si e ser para outro diria respeito apenas à relação que estabelecem os momentos da coisa, não à determinação do conteúdo próprio a cada um deles. Dessa forma, a unidade, por exemplo, seria determinada em si mesma, estando ligada à multiplicidade somente enquanto se distingue dela tomando-a como algo oposto, já que na oposição o outro é sem dúvida suposto. A relação de oposição, em que se explicita a unidade entre o ser para si e o ser para outro, consequentemente, seria algo supérfluo ou externo ao ser próprio de cada momento.

Entretanto, na verdade o próprio conteúdo de cada momento só é determinado na sua relação com seu oposto. A coisa só se determina como unidade excludente quando põe como outra essência a multiplicidade, da mesma forma que o conteúdo desta (a multiplicidade de propriedades) nada mais é do que a negação da unidade. Assim, a unidade entre ser para si e ser para outro diz respeito necessariamente também ao próprio conteúdo da coisa.

Para Hegel, essa conclusão é universal, de modo que qualquer ser só "é" enquanto universal incondicionado. Não há conteúdo que escape a essa determinação, pois, como ele afirma, "um tal conteúdo seria qualquer modo determinado de ser para si e relacionar-se com 
outro. Só que, ser para si e relacionar-se com outro, em geral constituem a natureza e a essência de um conteúdo cuja verdade é ser Universal incondicionado" (FE, p. 96, § 134). Ou seja, qualquer conteúdo é igual a si mesmo e nisso, como demonstrou a experiência da percepção, está unido ao seu oposto e sua verdade é o universal incondicionado.

"Porém [afirma Hegel], a diferença entre forma e conteúdo emerge nesse Universal incondicionado, por ser ele objeto para a consciência" (FE, p. 96, § 135). Isto é, na medida em que o universal incondicionado é para a consciência algo objetivo, ela tem de considerá-lo completamente determinado em si mesmo. Separando forma e conteúdo, a consciência imagina que isso seja possível, pois aí o objeto mesmo estaria completo em seu conteúdo enquanto a unidade entre os opostos diria respeito à forma dos momentos um em relação ao outro. Assim, quando ao conteúdo, a coisa seria, "[...] por um lado, um meio de 'matérias' subsistentes; e por outro, o uno em si refletido, no qual sua independência se aniquila. $O$ primeiro momento é a dissolução da independência da coisa, ou a passividade que é um ser para Outro. O segundo momento é o ser-para-si" (FE, p. 97, § 135). Sob o ponto de vista do conteúdo a coisa seria a unidade e o meio de matérias livres e sob o ponto de vista da forma a coisa seria o ser para si e o ser para outro.

Mas é importante reparar também que Hegel acrescenta à simples descrição dos momentos em sua dissociação a relação de equivalência entre forma e conteúdo e a própria ideia de que no fundo cada momento, tanto da forma quanto do conteúdo (ainda mais considerando que são equivalentes) está unido a seu outro. No primeiro caso, basta observar que ele estabelece uma relação entre o meio de matérias subsistentes e o ser para outro, assim como entre o uno em si refletido e o ser para si. A multiplicidade determina-se como o oposto da unidade. Isso significa que a coisa só é um meio de matérias independentes porque se diferencia em relação ao seu ser uno, ou em outras palavras, porque é um ser para outro. Ou seja, o conteúdo da coisa, segundo o qual ela é um meio de propriedades independentes, não é nada mais nada menos do que o diferenciar-se da coisa, seu ser para outro. Da mesma forma, a coisa só é uma unidade porque as propriedades diversas de que se constitui refletem sobre si, relacionam-se consigo mesmas ou são para si. Ou seja, o conteúdo da coisa só é o ser uno porque ela voltou a si (ser para si) a partir da diversidade de seu ser. Forma e conteúdo são, portanto, equivalentes.

Quanto ao outro aspecto, o de estarem os momentos da forma e do conteúdo no fundo em uma unidade, cabe destacar duas expressões importantes no que foi transcrito de Hegel acima. Em primeiro lugar, no uno em si refletido a "independência se aniquila". Como se disse antes, a coisa só se determina como una quando volta a si mesma a partir de sua diversidade. Então a unidade tanto quanto o ser para si (já que se mostrou que são equivalentes) dependem do ser para outro ou da multiplicidade. Em segundo lugar, Hegel afirma que o meio universal de muitas matérias é a "dissolução da independência da coisa". Na verdade essa expressão é equivalente a anterior. Na medida em que a coisa só é múltipla no seu diferenciar-se da unidade, o ser que surge desse movimento depende de seu ponto de partida, a própria unidade. Desse modo, embora a consciência diferencie forma e conteúdo e insista em procurar para o objeto um conteúdo dado, segundo a argumentação hegeliana forma e conteúdo são equivalentes e cada momento só é pelo seu outro, de modo que nenhum conteúdo pode ser determinado sem essa unidade. 
O ponto de vista de Hegel, como se disse antes, é o do filósofo que já alcançou o final do processo e sabe exatamente o que está em jogo nele. É a partir desse ponto de vista que as afirmações acima, a respeito da correspondência entre forma e conteúdo e da unidade entre seus momentos, têm sentido. Também a partir desse ponto de vista, Hegel pode afirmar que os "[...] momentos pelo fato de só estarem nela [na universalidade incondicionada], em geral não podem ficar separados um do outro; mas são essencialmente lados que neles mesmo se suprassumem; e o que se põe é unicamente o transitar de um para o outro" (FE, p. 97 , § 135). Essa é uma antecipação a respeito do que o próprio entendimento vai experienciar devido ao fato de buscar um conteúdo determinado para seu objeto indiferentemente ao que ele reduz à forma. Por estarem necessariamente em uma unidade, como Hegel mostrou antes, os momentos separados mostrar-se-ão evanescentes, dependentes de seu oposto, e levarão a consciência a inverter em cada momento sua consideração a respeito da verdade. Essa conclusão evidentemente só é possível ao filósofo, que conhece exatamente que elementos estão em jogo naquilo que o entendimento toma por universal incondicionado. Mas Hegel quer sobretudo mostrar que esse processo desenvolve-se no próprio entendimento, a partir de seu modo característico de tomar a verdade. Assim, ele se propõe a descrever a experiência que, como entendimento, a consciência realiza. 


\section{AS EXPERIÊNCIAS DO ENTENDIMENTO COM A FORÇA}

Nesta seção, reconstruir-se-á a exposição hegeliana da experiência que o entendimento realiza na tentativa de apreender a verdade na forma de um universal incondicionado. O movimento ininterrupto, compreendido nele, entre unidade e multiplicidade, entre identidade e diferença, será determinado aqui como força. A força, portanto, surge como nova forma de a consciência interpretar a dialética que já ocorria na percepção.

\subsection{Origem e determinação da força}

Hegel inicia a exposição das experiências do entendimento com a força considerando o ponto em que o entendimento atém-se à coisa enquanto meio universal em que subsiste uma multidão de matérias independentes. Para ele, nessa situação "[...] cada uma dessas 'matérias' está onde está a outra; interpenetram-se mas sem se tocarem” (FE, p. 97, § 136). Ou seja, a indiferença das matérias nada mais é do que o meio onde estão. Ou melhor, as matérias só são indiferentes porque se encontram num meio de indiferença. Isso significa que na verdade o ser das matérias independentes é o meio único de indiferença pelo qual elas são determinadas como independentes entre si. Com essa consideração, a coisa deixa de ser um meio indiferente para ser o que sustenta a indiferença - a unidade. Entretanto, acrescenta Hegel, "[...] esse Ser-suprassumido - ou a redução dessa diversidade ao puro ser para si não é outra coisa que o próprio meio; e esse é a independência das diferenças" (FE, p. 97, § 136). Ou seja, a coisa como unidade nada mais é do que a volta a si de suas matérias diversas. Consequentemente, a determinação da unidade é a própria diversidade, e ela volta a ser a essência da coisa. Fica comprovado o que Hegel já tinha dito que ocorreria: o transitar constante entre a unidade e a multiplicidade.

Aos moldes do que aconteceu na percepção, essa conclusão é a princípio negativa, já que por ela chega-se ao ponto de tomar a essência objetiva como um não ser, na medida em que os momentos em que ela era procurada, a multiplicidade e a unidade da coisa, mostraram-se evanescentes. Entretanto, a conclusão negativa revela imediatamente seu significado positivo: a essência da objetividade como movimento entre o uno e o múltiplo. E, acrescenta Hegel,

esse movimento é aquilo que se chama força. Um de seus momentos, a saber, a força como expansão das 'matérias' independentes em seu ser é sua exteriorização; porém a força como ser-desvanecido dessas 'matérias' é a força que, de sua exteriorização, foi recalcada sobre si, ou a força propriamente dita. Mas em primeiro lugar, a força recalcada sobre si tem de exteriorizar-se; e em segundo lugar, na exteriorização ela é tanto força em-si mesma essente, quanto exteriorização nesse ser-em-si-mesmo (FE, p. $97, \S 136)$. 
Observe-se que aquilo que o entendimento toma por verdade agora nada mais é do que o que foi posto como tal na experiência da percepção da coisa de muitas propriedades. Cada momento (o uno e o múltiplo) separadamente desvaneceu, pois mostrou ser o outro (seu oposto) o essente e converteu-se nele. Mas o que não desvaneceu foi justamente esse transitar necessário de um a outro, pois este é justamente a condição necessária do desvanecer de cada momento. Em outras palavras, tudo mais desvanece, mas não desvanece o desvanecer, pois é só por ele não desvanecer que tudo mais desvanece. O que se mantém, assim, é o transitar constante ou o movimento entre o uno e o múltiplo, que é posto na forma de uma essência objetiva - a força.

Para determinar o que seja a força, basta observar o que é desenvolvido no movimento que ela compreende. Ora, a força é, como se disse, o movimento entre os momentos da unidade e da multiplicidade. O fato é que, ao tomar a essência objetiva como unidade, a consciência observou que se tratava da unidade de propriedades diversas. Então, a essência inicial, una, desdobrou-se numa multidão de diferenças. Mas, por outro lado, esse ser múltiplo não poderia ser outra coisa que a própria essência inicial una. E assim a consciência voltou a reunir as propriedades diversas numa unidade. Agora, esse movimento, que a princípio era um puro desvanecer, é posto como essente: é a força. Consequentemente, a força não é nada mais nada menos do que o próprio movimento pelo qual a unidade desdobra-se em matérias diversas e estas tornam a ser a mesma essência presente na unidade. Assim, a força tem de apresentar-se sob dois momentos: como desdobramento de matérias diversas ou como força exteriorizada e como voltar a si desses momentos ou como força recalcada em si.

$\mathrm{Na}$ força exteriorizada, subsistem matérias diversas. Entretanto, elas no fundo são ainda força e por isso voltam à unidade ou ao recalcamento em si. Aliás, isso explica o que Hegel disse no trecho acima, a saber, que a força recalcada em si é a força como tal. É que, no desdobramento, as matérias diversas que aí se expandem também são força, como também já se disse. Mas, sendo força, não estão num ser desdobrado, porque o desdobramento supõe diferenciação e enquanto todas as matérias são força não há diferença e sim unidade. Assim, enquanto toma-se a força em seu sentido próprio, está-se no momento de seu recalcamento em si. Contudo, força, como foi determinado, é movimento. Então, a força como tal não pode permanecer em sua unidade inerte. Para isso, as diferenças têm de ser novamente postas, ou, em outras palavras, a força como tal tem de desdobrar-se. Esse é, pois, o momento de sua exteriorização, que lhe é da mesma forma necessário.

Como se pode ver, a força é mediante seus dois momentos. Isso significa que ambos só existem enquanto força, ou seja, ambos estão unidos sob o ser da força. Mas, na forma como estão postos acima, são tratados como momentos distintos. Para Hegel, isso só é possível porque aí "[...] o entendimento - ao qual o conceito de força pertence - é o conceito propriamente dito, que sustém os momentos distintos como distintos, pois na força mesma não devem ser distintos; a diferença, portanto, está só no pensamento" (FE, p. 97, § 136). Ou seja, devido ao fato de o recalcamento em si e a exteriorização serem simplesmente modos de a força se apresentar, eles não podem ter subsistência autônoma. O único ser que se apresenta no mundo real é a força mesma, em cuja unidade ambos os momentos estão 
presentes. A distinção entre eles, portanto, só é possível enquanto pensamento da força, não enquanto sua realidade.

Entretanto, afirma Hegel, "a força é o Universal incondicionado, que igualmente é para si mesmo o que é para um Outro; ou que tem nele a diferença, pois essa não é outra coisa que o ser-para-um-Outro" (FE, p. 98, § 136). Tomando o universal como um ser composto por várias propriedades ou matérias livres, seu ser para si é a volta dessas diferenças à essência comum e, portanto, à unidade. Mas no momento em que esse universal se diferencia de outro, ou seja, determina-se, é preciso que fiquem ressaltadas suas propriedades peculiares. Consequentemente, o universal torna-se uma multidão de matérias livres. Isso significa que no momento em que o universal se determina, é para outro, ele sai de sua pura igualdade consigo mesmo para ter ressaltadas as suas diferenças. Mas como meio dessas diferenças, o universal é diferente inclusive de si mesmo, enquanto identidade simples. Inicialmente, a percepção, como já foi mostrado, tentou separar os dois momentos. Pelo sucumbir de todas as suas tentativas, surgiu o universal incondicionado, em que os dois momentos diferentes, o ser para si e o ser para outro, tornam-se constituintes de uma mesma essencialidade. Ora, a força é o universal incondicionado, já que surgiu com essência dos dois momentos acima. Então, tendo em si o ser para si e o ser para outro, a força acolhe em seu íntimo a diferença. Por outro lado, antes ficou determinado que os momentos da força só estão distintos no pensamento (no conceito), não na realidade. Mas, sem ter em si os momentos distintos como distintos, a diferença ficaria excluída da força, que estaria presente apenas em sua igualdade consigo mesma. Então, na medida em que a força tem de ter em si a diferença, é preciso admitir que ela tem em si os momentos distintos como distintos. Como afirma Hegel, "a força como tal, ou como recalcada em si, é portanto para si como um Uno exclusivo, para o qual o desdobramento das matérias é uma outra essência subsistente; e desse modo são postos dois lados diferentes e independentes" (FE, p. 98, § 136). Ou seja, por ser universal incondicionado, a força precisa ter em si a diferença. Isso, por sua vez, só é possível se seus momentos essenciais forem efetivamente distintos. Para o recalcamento em si, consequentemente, a exteriorização tem de ser uma outra essência e vice-versa. Como são essências diferentes, cada uma tem de ser também independente da outra. Para cada essência, tudo que é outro em relação a ela tem de ser excluído de sua constituição. Se não fosse assim, ela não seria efetivamente diferente. Desse modo, a força só se torna efetiva através do ser independente de cada um de seus momentos e da mútua oposição entre eles.

Como já se pode ver, há duas determinações essenciais no que concerne à força. Por um lado, "[...] a força é também o todo. [...] Quer dizer: essas diferenças permanecem puras formas, superficiais momentos evanescentes" (FE, p. 98, § 136). Ou seja, o recalcamento em si e o desdobramento são apenas modos de a força apresentar-se e, por isso, não têm subsistência própria. O ser que, por assim dizer, os sustenta é a força. Por outro, "as diferenças entre a força propriamente dita, recalcada sobre si, e o desdobramento das 'matérias' independentes, de fato também não seriam, se não tivessem uma subsistência [...]. Mas existir sob esses modos contrários não significa outra coisa senão que os dois momentos são, ao mesmo tempo, independentes" (FE, p. 98, § 136). Quer dizer, a diferença, que, como se mostrou antes, tem de estar presente na força por ser ela um universal incondicionado, implica que cada momento não é o outro. Essa oposição, por sua vez, nada mais é do que a 
afirmação de que o ser de um não é o ser de outro. Mas para cada momento opor-se ao outro, tem de ter uma subsistência própria a partir da qual possa estabelecer-se como uma entidade distinta. Em outras palavras, a diferença entre os momentos ou a oposição entre eles supõe que sejam entidades independentes umas das outras. Essa situação geral da força, ser ao mesmo tempo o todo de seus momentos e a oposição entre lados distintos e independentes, faz com que sua realização implique um movimento pelo qual seus dois momentos "[...] sem cessar se fazem independentes para de novo se suprassumirem” (FE, p. 98, § 136). Essa afirmação, por ser expressão da verdade profunda do que está em jogo no conceito de força, é mais uma antecipação de Hegel, que deverá ser confirmada pela exposição da experiência que o próprio entendimento vai realizar sobre seu objeto. Ela é importante na medida em que possibilita ao leitor da Fenomenologia do espírito compreender todos os problemas que vão surgir depois, a partir de um fio condutor - o conflito entre o fato de a força ser a unidade de seus momentos e de precisar, ao mesmo tempo, mantê-los como distintos. Segundo a antecipação hegeliana, isso vai fazer com que a realidade da força se apresente para o entendimento num transitar ininterrupto entre a independência dos momentos e a suprassunção dos mesmos numa unidade. E é justamente em torno dessa situação que vai se dar a experiência do entendimento a respeito da força, assim como é acompanhada pelo olhar da descrição fenomenológica. Então, o próximo passo é verificar como é que o entendimento, a partir da descoberta de que a força é a verdade que ele procura, vê-se imerso nesse movimento de diferenciação e suprassunção da diferença.

\subsection{A força como verdade do movimento do perceber}

Antes, porém, é importante mencionar uma observação preliminar adicional de Hegel a respeito do movimento que ele imagina desenvolver-se no entendimento, conforme explicitado acima. Para ele, "[...] esse movimento não é outra coisa que o movimento da percepção, no qual ambos os lados - o percebente e o percebido - são ao mesmo tempo, de uma parte, um só e indistinto, como o apreender do verdadeiro; mas igualmente de outra parte, cada lado reflete sobre si, ou é para si” (FE, p. 98, § 136 ). Trata-se, pois, de uma analogia estrutural entre o que ocorreu na percepção e o que vai ocorrer no entendimento. Talvez até mais do que isso. Hegel parece estar não só indicando uma analogia possível entre duas situações diversas, mas preferencialmente afirmando tratar-se no fundo de uma mesma essência que se desenvolve em dois contextos distintos. Em todo caso, antes de mais nada cabe explicitar qual é a estrutura comum a que Hegel se refere. Ora, na percepção a verdade era a coisa de muitas propriedades. O problema que daí surgiu foi conciliar o fato de que, por um lado, a coisa deveria ser o meio indiferente de todas as propriedades e, por outro, a unidade diferenciada a partir da mútua relação dessas propriedades. Enquanto simplesmente universal, a coisa era apenas um composto de propriedades que estavam nela sem se tocarem. Mas enquanto uma coisa determinada, suas propriedades deveriam também ser determinadas, e por isso tinham de distinguir-se entre si. Segundo o primeiro aspecto, a coisa poderia ser, por um lado, uma multiplicidade de propriedades indiferentes. Mas, por outro lado, a multiplicidade não seria mais do que a simplicidade do meio que lhes permitia a relação de indiferença, e a coisa voltava à unidade. Com relação ao segundo aspecto, a coisa poderia 
ser, por um lado, a multiplicidade de propriedades entre si diversas e opostas. Mas, por outro lado, assim como antes, a relação de oposição não seria mais do que a determinidade da própria coisa enquanto una. Essa foi a situação em que de imediato a percepção se viu imersa. Como saída, ela tentou tomar as propriedades como determinadas, para que a própria coisa pudesse também determinar-se, e ao mesmo tempo indiferentes, para que a coisa conservasse sua universalidade. Entretanto, essa alternativa levou a um paradoxo ainda maior. Um ser determinado em si mesmo, indiferente a tudo mais, não poderia ser nada além do que o próprio singular visado da certeza sensível, que já tinha sido descoberto em sua inessencialidade. Ora, o singular, pela própria experiência da certeza sensível, mostrou não ser a verdade. Também por ela chegou-se ao ponto de considerar o universal o verdadeiro. Isso deu à percepção ao menos uma certeza: o singular sensível não pode ser o real, e por isso o universal tem de sê-lo. A descoberta de sua falsidade, assim, não poderia ser legítima. A falha não deveria ser atribuída à coisa de muitas propriedades, mas antes ao perceber.

Aqui é que surgem os dois pólos de que fala Hegel, o perceber e o percebido. Na medida em que o percebido foi tomado como a verdade, a falha deveria ser atribuída a uma percepção ilusória. A coisa, assim, era o uno. Nesse momento, perceber e percebido são um só. Mas o perceber refletiu sobre si e se deu conta de que o uno é um uno de propriedades diversas, e assim a coisa deveria ser antes uma multiplicidade. Já que a verdade já tinha sido determinada como uno, a multiplicidade deveria ser descontada da consideração da coisa como tal. Gera-se aí um descompasso entre percebente e percebido. Mas este também reflete sobre si. Ou seja, a consciência se dá conta de que a própria coisa não seria determinada se não guardasse em si propriedades distintas específicas. Assim, a coisa é antes uma multiplicidade de propriedades.

Esses exemplos já servem para explicitar o paralelo que Hegel aponta entre o momento da força e o do perceber. Neste, como se viu, inicialmente percebente e percebido são equivalentes. Mas a reflexão sobre si da coisa, em que do uno ela é lançada à multiplicidade e vice-versa, a torna tão inessencial que a consciência se vê forçada a considerar justamente esse ato reflexivo como seu, separando-o da coisa. Nesse ponto, cada momento da coisa teria seu oposto, ao menos inicialmente, não em um princípio objetivo, que o tornaria evanescente, mas no perceber, de modo que o múltiplo não seria posto ao lado do uno, mas numa esfera separada. O perceber do múltiplo, assim, é a reflexão sobre si do uno, assim como a unidade é a reflexão sobre si do múltiplo, e em ambos os casos mediante a cisão entre a coisa percebida e o perceber. Essa é a mesma situação do entendimento relativamente à consideração de sua verdade - a força. $O$ uno reflete sobre si e nisso revela ser no fundo uma porção de matérias livres, da mesma forma que a multiplicidade em si não é mais do que a força em seu ser uno. Não há mais, é verdade, aquele tipo de cisão entre percebente e percebido. Agora, a partir dos resultados da experiência da percepção, o que era separado entre a coisa e a consciência é posto como princípio da própria objetividade. Então, no fundo, como assinala Hegel, o movimento que vai se desenvolver agora é exatamente o mesmo que já ocorria na percepção. A única diferença é que a consciência não vai mais fazer uso da separação sofística entre percebente e percebido, já que nesse ponto ela já sabe que isso é exatamente um artifício sofístico. Em outras palavras, pode-se dizer, com Hegel, que o movimento da força na experiência do entendimento é o mesmo movimento que ocorria na 
percepção porque ele é a verdade deste. Essa é, portanto, a verdadeira relação que Hegel pretende assinalar. Cabe ver, então, como a experiência do entendimento sobre seu objeto vai se desenrolar propriamente.

\subsection{0 desdobramento da força em solicitada e solicitante}

Para o entendimento, a verdade é o universal incondicionado. Devido ao modo como ele o concebe, o incondicionado é para ele força. Portanto, o entendimento vê-se agora na situação de quem simplesmente contempla a verdade como força.

O entendimento, desse modo, para estar de posse da verdade, tem de conhecer a força como tal, já que ela é a verdade. Entretanto, a força como tal não é mais do que a volta à unidade das diferenças contidas na força. Isso significa que, além da força enquanto tal, também deve estar presente, na consideração da força, a sua exteriorização. Mas, quando o entendimento toma a força em sua volta a si mesma, em sua unidade, exclui de sua consideração o desdobramento, pois a unidade é justamente o oposto da diferenciação. Consequentemente, nesse ponto o entendimento só pode tomar o subsistir de matérias desdobradas como outra essência em relação à força em si mesma. E, segundo Hegel, "já que é necessário que a própria força seja esse subsistir, ou que se exteriorize, sua exteriorização se apresenta sob a forma de algum Outro que a aborda e solicita. Mas de fato, enquanto se exterioriza necessariamente, tem nela mesma o que era posto como uma outra essência" (FE, p. 99,§ 137). Como se vê, trata-se de uma tentativa, por parte do entendimento, de conciliar o fato de que a força enquanto tal, que se mostra para ele como a verdade, é uma unidade e por isso exclui de si o desdobramento com a necessidade de exteriorização, imposta pela própria força. Sua tentativa consiste em tomar a exteriorização também como força, mas não com a mesma essência do recalcamento em si, já que ambos são opostos. Então, a força enquanto tal realizaria sua necessidade de exteriorização por via de outra essência que solicitaria seu desdobramento. Mas, como indica Hegel, essa posição é insustentável. Na medida em que na própria força como una está posta a necessidade do desdobramento, é a partir dela mesma que ele é necessário e portanto essencial.

A força tornou-se, então, o oposto do que era antes. Agora ela é o meio de matérias desdobradas. Mas as matérias desdobradas são todas força, como já se disse. Isso significa que elas no fundo estão ainda na unidade da força. E como a força agora é tomada como meio de matérias desdobradas, o ser uno só pode ser considerado enquanto um momento oposto a esse ser múltiplo. Assim, a unidade torna-se, analogamente ao que ocorreu antes, outra essência que aborda a força desdobrada e solicita sua reflexão sobre si. Entretanto, "[...] ela mesma é esse ser-refletido-em-si, ou esse ser-suprassumido da exteriorização" (FE, p. 99, $\S 137)$. Ou seja, pela força ser também a reflexão sobre si ou a volta à unidade, esta não pode ser posta como uma outra essência em relação à força desdobrada. Na medida em que as matérias desdobradas são força, têm de estar na unidade de seu ser e por isso a força é antes essa suprassunção da exteriorização numa unidade.

A força com tal tem de diferenciar-se, pois a força é também o desdobramento das matérias livres. Da mesma forma, na exteriorização não há nada além do que a própria força, e as matérias diferenciadas voltam à unidade. A tentativa do entendimento, como se indicou 
acima, foi considerar o momento, que surge ao lado do que é considerado como força, outra essência solicitante. Entretanto, a necessidade do outro momento inscrita na intimidade do primeiro indica que na verdade a essência deste é aquele. Consequentemente, cada momento, ao mesmo tempo em que se opõe ao outro, desvanece diante dele. Entretanto, também algo de novo surgiu. Como diz Hegel, "a oposição, em vez de permanecer de modo totalmente essencial, um momento apenas, parece ter escapado ao domínio da unidade por meio do desdobramento em forças totalmente independentes" (FE, p. 99, § 138). Os dois momentos mencionados são, evidentemente, as forças solicitante e solicitada. O uno mostrase dependente do múltiplo, e vice versa. Mas o solicitar apareceu como algo totalmente independente do ser solicitado. Nesse caso, o entendimento poderia ter encontrado agora as diferenças subsistentes em si mesmas, necessárias para que a força seja a unidade dos momentos diferentes como diferentes. Para certificar-se disso, o entendimento deve "[...] examinar mais de perto qual é mesmo a situação dessa independência" (FE, p. 99, § 138).

$\mathrm{Na}$ experiência acima descrita, o solicitar surgiu quando a força foi tomada como uno, e a necessidade de exteriorização teve de ser atribuída à ação de outra essência sobre a primeira. A solicitante, assim, foi posta como o meio universal de matérias independentes. No momento seguinte, porém, a força converteu-se no que the era oposto - o meio universal. Consequentemente, a força solicitante tornou-se a unidade em si refletida. Conforme salienta Hegel, isso significa que ela

[...] de fato só é igualmente meio universal quando é solicitada a que o seja. Do mesmo modo, também só é unidade negativa - ou o que solicita a força ao retornar por ser solicitada. Por isso transmuda-se também, nessa troca recíproca de determinações, a diferença que se estabelecia entre as duas forças, em que uma devia ser a solicitante, a outra, a solicitada (FE, p. 100, § 138).

Quando se considera a força como a unidade de seus momentos, está-se tomando a força enquanto tal ou recalcada em si. Como consequência imediata, a força enquanto meio de matérias desdobradas passa a ser outra essência, que solicita à unidade sua exteriorização. Ora, solicitante é aquela força que age sobre a outra determinando-a. É isso o que a força como meio faz em relação à unidade. Mas é isso também o que faz a unidade em relação ao meio, pois a força como meio só é solicitante se for anteriormente determinado que a força recalcada em si é a solicitada. Em outras palavras, a solicitante só é solicitante se for antes solicitada a sê-lo. Isso significa que a força solicitante é antes a solicitada, e a que foi tomada inicialmente como solicitada é na verdade solicitante. Essa mesma situação se repete quando, no momento oposto, toma-se a força solicitante como unidade: esta só é solicitante porque foi solicitada pelo meio universal a sê-lo. Com isso, tem-se um movimento semelhante ao que se desenvolvia entre a força recalcada em si e a sua exteriorização, pois também aqui cada momento põe-se como o oposto do outro e, consequentemente, como independente dele, mas ao final acaba revelando que o outro é sua própria essência e converte-se nele. A essência do lado tomado inicialmente como solicitante é antes seu oposto, a força solicitada, pois é ela a base de seu ser, já que só é solicitante na medida em que é solicitada a tornar-se solicitante. Então, a solicitante é antes seu oposto, a solicitada. Além disso, ainda em analogia ao que tinha ocorrido antes, pelo transmudar de determinações, também desvanece a diferença que deveria haver entre as forças solicitada e solicitante. Pela inversão de 
determinações de cada uma, fica explícito que ambas não são subsistentes por si mesmas, isto é, que cada uma desvanece enquanto se põe como diferente da outra por converter-se exatamente nela, ou ainda, que a independência de cada uma é antes um não ser (não tem subsistência). Assim, também aqui o entendimento não alcançou os momentos efetivamente diferentes necessários para que a força seja a unidade da diferença como diferença.

\subsection{A diferença entre forma e conteúdo}

As duas diferenças anteriores desvaneceram enquanto diferenças, já que cada momento mostrou ter no fundo sua essência em seu oposto. Mas nisso também surgiu uma nova diferença, cujos pólos são a forma e o conteúdo. Isso se deve ao próprio fato de que, segundo Hegel,

[...] as próprias diferenças se mostraram sob uma dupla diferença: primeiro, como diferenças do conteúdo pois um desses extremos é a força refletida sobre si mesma; mas o outro, o meio das 'matérias'. Segundo, com diferenças de forma, enquanto uma é solicitante, outra, solicitada; aquela ativa, esta passiva (FE, p. 100, § 140).

Em certa medida, essa é uma retomada da diferença, apresentada no final do capítulo sobre a percepção, entre unidade e multiplicidade, de um lado, e ser para si e ser para outro, de outro lado. As diferenças de conteúdo diriam respeito à determinação própria dos momentos da força. Aqui, a força ou é recalcada em si, ou é o meio de matérias desdobradas. Mas as diferenças de forma diriam respeito apenas à relação dos momentos entre si. Por esse aspecto, um momento é em relação ao outro ou força solicitante, ou força solicitada. Em cada um desses âmbitos de diferenciação, os respectivos momentos mostraram ser evanescentes. Entretanto, cabe saber se ao menos a diferença entre forma e conteúdo é possível. Para isso, o modo segundo o qual cada momento da força se determina deve ser independente da relação que esse dado momento possivelmente estabelece com outro.

Esse requisito, entretanto, não é realizado. Na verdade, a força solicitante é o mesmo que a força recalcada em si, assim como a força solicitada é o mesmo que o meio universal de matérias. O fato é que o recalcamento em si nada mais é do que a volta da força de seu ser outro, ou de seu ser diferenciado, para si mesma, para a unidade de uma só essência. Isso é justamente o que faz a força solicitante. Ela surge como o oposto da força solicitada e faz com que ela assuma sua determinação contrária, ou seja, que passe para o momento oposto. Ora, com essa passagem, desaparece a oposição que foi posta pela força solicitada em relação à solicitante, pois ela mesma põe sua essência no elemento de seu oposto e constitui, assim, uma unidade com ele (ou deixa de se diferenciar dele). Isso significa que a forma, a relação entre os momentos, sob o aspecto da força solicitada, tem como conteúdo a reunião em um só (a unidade, a força recalcada em si); e o conteúdo, a determinação dos momentos, no caso da força recalcada em si, tem como consequência formal (ou seja, como consequência para a relação entre os momentos), a instigação do movimento de um momento em direção ao outro (o solicitar). Assim, ao menos quanto a esse primeiro aspecto do paralelo entre forma e conteúdo, ambos são no fundo o mesmo.

Mas essa conclusão pode ser alcançada também no que diz respeito à relação entre força solicitada e meio universal de matérias desdobras. Segundo o conteúdo, a força $87^{\circ}$ 
exteriorizada é o momento da oposição em relação ao ser para si, em que é deixada de lado a unidade das matérias sob uma só essência em vista da diferenciação efetiva. Ora, a força solicitada, no aspecto da forma, é exatamente isso, ou seja, o momento em que surge, ao lado do que é tomado com força, o outro momento que lhe é oposto. Em outras palavras, enquanto solicitada, a força está determinada como um oposto em relação a um outro (ou tem um outro como seu oposto), e isso é exatamente o que ocorre quando o meio de matérias diferenciadas surge como um outro em relação ao recalcamento em si da força. A força solicitada, assim, tem em conteúdo: é a diferenciação da força em relação a uma unidade simples, ou o surgimento do ser oposto. Da mesma forma, a força exteriorizada implica uma relação específica: a oposição, a relação entre forças opostas. Como se vê, nos dois casos forma e conteúdo são, no fundo, o mesmo.

\subsection{O desvanecer do jogo de forças: o fenômeno e seu interior}

Pela primeira experiência, o entendimento chegou ao ponto de considerar o universal incondicionado como força, ou seja, como uma realidade sensível que contém em si, ou é a unidade de, o ser para si e o ser para outro, o uno e o múltiplo. Mas na medida em que a força foi determinada como uma unidade, nela esses dois momentos não poderiam estar separados. Consequentemente, essa distinção deveria ser atribuída ao pensamento e distinta da consideração da realidade.

Por outro lado, enquanto universal incondicionado, a força também deveria ter em si a diferença, o ser para outro. Isso significa que ao lado de cada momento deveria surgir seu outro e que a essência de um deveria ser distinta da essência do outro. A força como tal, assim, só seria efetiva se tivesse a diferença em si. Mas a força enquanto tal era antes a volta à unidade das diferenças, em que na verdade não havia efetivamente diferença alguma. Por isso, a diferença em relação à unidade teve de ser introduzida por meio da consideração de outra força que solicita à primeira que se exteriorize.

Entretanto, na medida em que a necessidade da exteriorização foi posta pela própria força recalcada em si, o momento que foi posto como outro na verdade era o mesmo, e a essência da força tornou-se o desdobramento. Da mesma forma, a força desdobrada pôs como outra essência solicitante a força recalcada. Mas, por ser ela mesma esse recalcamento, inverteu imediatamente sua determinação e tornou-se força recalcada. Com isso desvaneceram enquanto diferenças efetivas o recalcamento em si e a exteriorização.

Restou, como diferença na força, entretanto, o solicitar e o ser solicitado. Mas aqui também se desenvolveu o mesmo movimento de troca imediata de determinações e o consequente desvanecimento da independência dos momentos. A força solicitante só surgiu quanto foi solicitada, assim como só ao solicitar a força solicitada veio à tona. Resultou, por fim, a diferença entre forma e conteúdo, que, com mostrou-se, também é evanescente, pois o recalcamento em si nada mais é do que o solicitar, assim como a exteriorização equivale ao momento da força solicitada. Essas experiências em conjunto permitem concluir, segundo Hegel, que

[...] o conceito de força se torna efetivo através da duplicação em duas forças e [o modo] como se torna tal. Ambas essas forças existem como essências para si 
essentes; mas sua existência é um movimento tal, de uma em relação à outra, que seu ser é antes um puro Ser-oposto mediante um outro; isto é: seu ser tem, antes, a pura significação do desvanecer (FE, p. 101, §141).

Quando o conceito de força surgiu para o entendimento, foi determinado como o movimento entre o uno e a multiplicidade, o recalcamento em si e a exteriorização. Também foi determinado que a força, enquanto universal incondicionado, só seria efetiva se tivesse em sua realização a diferença enquanto tal. Como consequência, a realização da força teve de ser tomada como um processo em que seus dois momentos estão presentes com distintos e opostos. Em vista disso, os momentos deveriam ser também independentes, pois duas coisas só são opostas quando a essência de cada uma é outra em relação ao que ela põe como oposto. Assim, a realização da força significou, em primeiro lugar, a sua duplicação em duas essências totalmente distintas. Entretanto, com ficou explícito, cada uma é apenas mediante a outra. O recalcamento em si só é em relação ao desdobramento, pois sua determinação essencial é ser a volta à unidade das matérias diferenciadas. O desdobramento é nada mais do que a diferenciação das matérias que estão em uma unidade na força recalcada. A força solicitante só surge quando é posta sua oposição em relação à força solicitada, e vice-versa. Até mesmo a distinção entre forma e conteúdo só surge quando são tomados como opostos o que um momento é em si e a relação que ele estabelece com seu outro. Portanto, em todos esses casos fica explícito que cada momento só é enquanto um oposto, ou seja, que é pela relação de oposição que cada um vem a ser. Os momentos estão imersos numa tal condicionalidade recíproca, em que cada um é em si (isoladamente) um não ser.

Ora, essa conclusão surgiu da experiência a partir da qual o entendimento esperava alcançar a força em sua realidade efetiva. Mas a força só seria efetiva enquanto diferença efetiva, ou seja, mediante o subsistir autônomo dos seus momentos. Com eles mostraram ser evanescentes, a realização da força, como afirmou Hegel no trecho acima, "tem, antes, a pura significação do desvanecer". Assim, a realização da força, ou seja, a tentativa de concebê-la com um ser real, tem, ao menos a princípio, um significado negativo, segundo o qual o que se alcança é apenas um não ser. Mas há algo mais aí. Segundo Hegel, a partir do resultado das experiências do entendimento, também fica explícito que

\footnotetext{
a verdade da força permanece, pois, só como pensamento da mesma, e os momentos dessa efetividade, suas substâncias e seu movimento desmoronam em parar numa unidade indiferenciada - que não é a força recalcada sobre si (pois ela mesma é só um momento desses), senão que essa unidade é seu conceito, como conceito (FE, p. 101-2, § 141).
}

A força, enquanto unidade do ser para si e do ser para outro, não retém esses dois momentos como diferentes. Ou seja, enquanto ambos são força, não são distintos. Mas quando se diz que a força é a unidade de seus momentos, está-se diferenciando um do outro. E na verdade essa diferenciação é necessária, pois, enquanto universal incondicionado, a força precisa mesmo ter em si a diferença. Mas essa diferenciação dos dois elementos intrínsecos ao conceito de força não foi aceita inicialmente pelo entendimento, porque ela é realizada apenas no pensamento, não na realidade da força mesma. É preciso, segundo esse ponto de vista, que a força, em sua efetividade mesma, tenha em si a diferença, ou seja, tenha momentos que subsistam enquanto distintos. Foi justamente por isso que o 
entendimento tentou encontrar a força, na sua realidade sensível, como uma essência constituída por dois elementos independentes e opostos. Entretanto, como se viu, todas as experiências revelaram que na realidade da força os momentos não são efetivamente distintos. Quando se toma a força como tal, para ver as diferenças que há nela, está-se considerando apenas o momento do recalcamento, da volta das diferenças à unidade de uma só essência, em que não há mais diferença alguma. Então é preciso que o momento oposto a este esteja presente, para que a diferença seja efetiva.

Por outro lado, quando as diferenças são repostas, não se tem a força como a unidade entre elas, que é do mesmo modo necessária. Mas o oposto do recalcamento, a exteriorização de matérias, é também força. Então, ambos estão realmente numa unidade. Só que nesse momento já deixaram de ser diferenças efetivas. Cada um, portanto, transmuda-se imediatamente no outro, de modo que não é possível alcançar a força como a unidade de momentos diferentes. Assim, pela experiência do entendimento fica demonstrado que a força, enquanto realidade sensível, é um não ser.

Entretanto, o entendimento é capaz de apossar-se da força como um essente. Não enquanto realidade empírica, é verdade, mas enquanto pensamento, como foi dito inicialmente. Ou seja, ao menos no conceito de força seus dois momentos, o recalcamento e a exteriorização, estão numa unidade que é ao mesmo tempo diferenciada (os momentos são ainda distintos). Isso significa que "a realização da força é assim, ao mesmo tempo, a perda da realidade" (FE, p. 102, § 141). Ou seja, a força só se torna efetiva, como unidade da diferença como diferença (do ser para si e do ser para outro, como foi determinado inicialmente), deixando de ser um ente sensível e sendo conceito.

Aliás, desde o início a força só poderia ser um essente para o entendimento enquanto ele a mantinha como tal, já que, segundo o que ele sabe agora, a força na realidade esvanece. Então, desde o início a força é conceito, mas só agora ela é conceito como conceito, ou seja, só agora o entendimento reconhece sua natureza conceitual e deixa de buscá-la como uma essência sensível.

Desse modo, a experiência realizada pelo entendimento até aqui tem um duplo significado. Em primeiro lugar, mostrou a falsidade daquilo que era para ele a verdade, ou seja, a força como um ente sensível. Aqui o entendimento alcança o momento da negação de seu objeto. Entretanto, e em segundo lugar, essa negação é nela mesma antes uma afirmação, já que por ela sabe-se agora que a força, a unidade entre ser para si e ser para outro (o universal incondicionado), não é possível como algo real, mas apenas como conceito. Para o entendimento, isso significa que "o primeiro universal seria a força recalcada sobre si, ou a força com substância; mas esse segundo universal é o interior das coisas como interior idêntico ao conceito como conceito" (FE, p. 102, § 142).

Ao buscar a unidade entre ser para si e ser para outro como um ente real, o entendimento alcança apenas o momento da força recalcada em si mesma, ou seja, a volta à unidade dos momentos distintos; afinal, numa unidade real, tornada ser concreto, as diferenças deixam de ser efetivas pois passam a compor uma mesma subsistência. Como a verdade não pode estar na realidade sensível, mas tem de estar ao mesmo tempo presente, ela só pode ser o que não é o sensível, e o que é tomado como não sensível por excelência é conceito. Mas o conceito, a partir do modo com surgiu, não é uma mera representação do 
pensamento. Ele é antes a verdade do desenrolar da força na realidade sensível. Por isso, o conceito é aqui o interior das coisas, a verdade mais profunda daquilo que acontece no mundo empírico; estando, no entanto, para além dele mesmo (interior).

De imediato isso transforma o modo como o entendimento toma sua relação com a verdade. Antes ela era contemplada imediatamente. Entretanto, na medida em que passou ao interior, "essa verdadeira essência das coisas está agora determinada de maneira que não é imediatamente para a consciência, senão que essa tem uma relação mediata com o interior; e, como entendimento, divisa através desse meio termo, que é o jogo de forças, o fundo verdadeiro das coisas" (FE, p. 102, §143). Vê-se, portanto, que junto com o sucumbir de um modo de ver a verdade também desvanece a maneira correspondente de considerar a relação com ela. Mais ainda, da mesma forma que a negação de uma verdade tem um sentido positivo, o sucumbir de um modo de considerar a relação com ela implica necessariamente a constituição de uma nova relação. Pela descoberta de que a força real (sensível) é um não ser, o entendimento passou a considerar a verdade como o que está para além da força em sua realidade sensível: o interior das coisas.

É evidente que, mesmo na primeira e negativa consideração dessa descoberta, está implicado o desvanecer do modo como o entendimento tomava a verdade. Isto é, se a verdade não é o sensível, não é pela contemplação imediata deste que se pode alcançá-la. Nisso, por sua vez, está implicado o novo modo legítimo de apreender a verdade: não imediatamente, mas mediatamente. A mesma conclusão é extraída do novo conceito de verdade. $\mathrm{Na}$ medida em que ela é o interior das coisas, não pode ser apreendida imediatamente, pois está para além do que é imediato.

Com isso está determinado também um novo papel ao jogo de forças. Antes ele era o próprio lugar da verdade. Agora ele é o meio através do qual a verdade pode ser alcançada, pois foi só através do movimento de desvanecer constante presente nele que o interior das coisas surgiu para o entendimento.

Além disso, em relação à natureza própria do jogo de forças, na medida em que ele é um evanescente, segundo Hegel,

[...] se chama fenômeno; pois a aparência é o nome dado ao ser que imediatamente é em si mesmo um não-ser. Porém, não é apenas um aparecer, mas sim fenômeno, uma totalidade do aparecer. Essa totalidade como totalidade ou universal é o que constitui o interior: o jogo de forças como sua reflexão sobre si mesmo (FE, p. 102, § 143).

O entendimento pensava apossar-se da verdade através da contemplação da força em sua realidade empírica. Mas ao tentar fazer isso, deparou-se com o jogo de força, em que ocorre a passagem de cada determinação que deveria ser essencial a seu oposto, que nada mais é do que o próprio desvanecer da força. Considerando essa situação a partir do ponto em que seu significado positivo já foi alcançado, qual seja, a descoberta da verdade como interior, ela (a situação do jogo de forças) nada mais é do que um movimento destituído de essência em si mesmo, ou o desdobramento de algo não presente no próprio desdobrar. Para Hegel, isso é justamente o que se compreende por fenômeno e aparência: embora sejam alguma coisa presente, são distintos daquilo que "é" em sentido pleno, a essência, que fica escondida por trás deles. 
O fato é que tudo que existe tem uma subsistência, algo que lhe sirva de base. Mas, no caso do jogo de força, o que existe é antes o sucumbir de toda base, de toda determinação fixa. Então ele só pode ser compreendido como fenômeno, ou seja, como uma manifestação cuja essência está para além dela mesma. O jogo de forças, segundo o ponto de vista do entendimento, existe. Mas existe enquanto um desvanecer de tudo o que poderia sustentar-se na existência. Por isso, na medida em que essa base para sua existência é necessária, tem de ser posta em algum ponto a salvo de seu sucumbir. Esse ponto é o interior. Consequentemente, o interior nada mais é do que a base necessária ao jogo de forças na medida em que ele revelou ser apenas um fenômeno.

Outro aspecto importante, presente no trecho acima, diz respeito ao fato de que é o fenômeno em sentido universal o que constitui o interior. Ao que tudo indica, essa ideia é no fundo a mesma presente na consideração do universal incondicionado como a unidade entre ser para si e ser para outro. O grande problema do entendimento foi tentar encontrar essa unidade num elemento sensível - a força. Tomando a força como tal, o entendimento alcançou apenas a volta das diferenças à unidade, que é somente um dos momentos da força e que por isso desvanece, já que no universal incondicionado tem de estar presente também o ser para outro. Agora o entendimento sabe que essa unidade só é possível no que está para além do sensível - o interior das coisas - que assim torna-se a nova forma de o universal incondicionado ser determinado. O interior surge, assim, como a essência das diferenças, pois as diferenças só "são" enquanto ancoradas numa essência comum. Ou seja, o interior é a essência do fenômeno e, portanto, a unidade de seu ser. Nada no fenômeno pode se furtar à volta à unidade simples de sua essência enquanto interior. Ou, em outras palavras, cada coisa só pode ser fenômeno na medida em que é sustentada pela essência que está no interior das coisas.

O fato é que não se pode compreender a aparência aqui com uma forma particular de manifestação de um ente ainda oculto. Não é que no sensível haja aparências, é que o sensível é aparência. Ou seja, não resta nenhuma essencialidade nele, tudo é desvanecer. Quando se diz que há aparências no mundo sensível, está-se supondo que resta ainda alguma essência nele e, mais ainda, que essas aparências são apenas formas distorcidas de o sensível se mostrar. Mas, segundo o ponto de vista em questão, a aparência no sensível não é uma falha ou uma exceção. Na verdade o sensível mesmo é aparência, de modo que nele não se encontra essência alguma. E é por que não há essência alguma no fenômeno que a sua reflexão sobre si ou a volta àquilo que é sua essência é a constituição do interior como sua verdade plena ou universal. 


\section{AS EXPERIÊNCIAS DO ENTENDIMENTO COM O SUPRASSENSÍVEL}

A tensão entre as forças não pode ser resolvida pelo entendimento senão pela postulação da existência de um mundo para além do fenômeno. Nesta seção, descreveremos as experiências através das quais esse novo mundo, o suprassensível, determina-se para o entendimento, a partir do mundo fenomênico.

\subsection{O suprassensível como verdade da força}

O interior das coisas é, portanto, a essência que falta à totalidade do movimento do jogo de forças e o faz ser fenômeno. Ele é o além essente alcançado através do aquém evanescente. Entretanto, parece haver algo de confuso na exposição hegeliana. Inicialmente ele afirmou que, pelo fato de as diferenças não poderem sustentar-se no jogo de forças, sua verdade deveria ser o conceito como conceito. Logo em seguida, entretanto, ele afirma, sem maiores explicações, que a verdade que o entendimento passa a considerar é o interior das coisas. O problema, então, é saber qual a diferença entre uma e outra forma de tomar a verdade e por que o entendimento considera o fato de que as diferenças só mantêm no conceito a afirmação de que a verdade é o interior das coisas.

De todo modo, sabe-se que a verdade surgiu para o entendimento a partir da constatação de que o jogo de forças é evanescente e por isso deve ter sua essência, a unidade de seus momentos, fora dele. Isso significa que a verdade, seja ela o que for, surgiu como resultado da reflexão a partir do fenômeno, ou seja, da sua volta a si mesmo (à sua essência). Em certo sentido, isso poderia ser considerado apenas um ato da consciência. "Mas [pondera Hegel], como é consciência, torna a fazer do verdadeiro um Interior objetivo: distingue, de sua reflexão em si mesma, a reflexão das coisas; como também, para ela, o movimento mediador é ainda um movimento objetivo" (FE, p. 102, § 143). Aqui está explícita tanto a diferença entre conceito e interior das coisas, quanto o motivo que leva a consciência a tomar a verdade como o segundo elemento.

O fato é que o entendimento, assim como a certeza sensível e a percepção, só admite como verdade o que é objetivo, o que tem como fundamento algo distinto da mera construção subjetiva. Para ele, a verdade tem de ser o pólo objetivo, oposto à subjetividade. Essa consideração funciona como guia em todas as suas experiências. Assim, o que o fenômeno põe como sua verdade, para além dele mesmo, tem de ter igualmente um significado objetivo.

Com isso, evidentemente, o entendimento se encontra imerso num paradoxo: por um lado, a verdade não pode ser a subjetividade; mas igualmente, a objetividade sensível é só fenômeno. Entretanto, a imersão nesse paradoxo, muito antes de impossibilitar qualquer verdade, é o suporte para um novo modo de entendê-la. Ou seja, pelo caráter necessário das 
duas diretrizes, a verdade é o não sensível objetivo (distinto do sujeito), ou seja, o interior (para além do sensível) das coisas (que são distintas do sujeito). Além disso, o próprio movimento pelo qual a verdade é alcançada é objetivo, ou seja, distingue-se dele próprio. Não é que o sujeito, ao buscar a essência do fenômeno, veja-se forçado a admiti-la como interior das coisas. É que o próprio fenômeno é um desvanecer objetivo que existe só na medida em que está amparado num interior essencial. Por isso, simplesmente observando-o, pode-se alcançar a verdade que nele mesmo é posta como um interior.

Para Hegel, com o surgimento do interior, "pela primeira vez, descerra-se sobre o mundo sensível como o mundo aparente, um mundo supra-sensível como o verdadeiro. Patenteia-se sobre o aquém evanescente o além permanente" (FE, p. 103, § 144). Em todos os momentos anteriores, a verdade foi tomada como o sensível objetivo ao alcance imediato da consciência. Na certeza sensível era o objeto singular visado. Na percepção tratava-se da coisa de muitas propriedades. Agora, entretanto, a verdade é determinada exatamente como o que está para além do sensível, ou seja, a verdade é o suprassensível. Consequentemente, como já foi indicado, a relação da consciência com a verdade não pode mais ser imediata. $O$ entendimento precisa agora do meio termo do fenômeno para alcançar o objeto que para ele é o verdadeiro.

Essa nova forma de o entendimento tomar a verdade e a relação com ela modifica também o objeto que a Fenomenologia do espírito tem de descrever. Antes tratava-se apenas da relação imediata entre a consciência e aquilo que para ela era a realidade. Agora, porém, "nosso objeto é [...] o silogismo que tem por extremos o interior das coisas e o entendimento, e por meio termo, o fenômeno. Pois o movimento desse silogismo dá a ulterior determinação daquilo que o entendimento divisa através desse meio termo, e a experiência que faz sobre esse comportamento do Ser-concluído-junto [com ele]" (FE, p. 103, § 145). Ou seja, para descrever a experiência que o entendimento faz na sua relação com a verdade, é preciso apanhar o modo como, segundo seu próprio modo de ver, ele se relaciona com ela. Se para o entendimento a verdade só é possível através da mediação do fenômeno, então é preciso acompanhar como ele a alcança através dessa mediação. Além disso, como indica Hegel, o entendimento mesmo só se conclui como consciência que possui a verdade através do meio termo, já que é por ele que ela é alcançada. Então, observando esse processo, poder-se-á saber também o que significa para o entendimento esse concluir-se junto com o próprio ato pelo qual a verdade é alcançada ${ }^{14}$.

\subsection{A determinação do suprassensível}

O interior das coisas ou o suprassensível surge como verdade do jogo de forças. Mas é preciso ainda que o entendimento determine essa verdade. Segundo Hegel, "para a consciência, o interior é ainda um puro. Além, porquanto nele não encontra ainda a si mesma:

\footnotetext{
${ }^{14}$ É interessante perceber que essa observação só pode ser compreendida quando se tem em mente o desenvolvimento posterior, em que o entendimento vai tornar-se consciência de si. Aliás, isso é corrente na exposição hegeliana: cada momento só é compreendido completamente quando é ultrapassado.
} 
é vazio, por se apenas o nada do fenômeno, e positivamente [ser] o Universal simples" (FE, p. 103, § 146). O interior surgiu simplesmente a partir da necessidade imposta pelo fenômeno de que existisse um ponto para além dele que se mantivesse firme (essência) diante de seu desvanecer. Consequentemente, ele foi constituído apenas como o que está para além do fenômeno e o mantém. Nisso também está dito que ele é um universal simples, pois surgiu como a volta à unidade de uma só essência dos momentos evanescentes no fenômeno.

A partir dessa conclusão, Hegel faz uma análise no mínimo interessante a respeito de algumas ideias acerca do suprassensível e do modo de relacionar-se com ele. Talvez se possa inclusive tomar alguns aspectos dessa argumentação como uma resposta crítica principalmente a Kant. Entretanto, não é possível aqui desenvolver essa abordagem. Basta, para os fins deste trabalho, reconstruir o próprio desenrolar da argumentação hegeliana.

A primeira ideia analisada por Hegel refere-se à afirmação de que o interior das coisas é incognoscível. Hegel concorda que essa afirmação seja verdadeira, "[...] não porque a razão seja míope ou limitada [...], mas pela simples natureza da Coisa mesma: justamente porque no vácuo nada se conhece; ou, expressando do outro lado, porque esse interior é determinado como o além da consciência" (FE, p. 103-4, §146). É interessante considerar essa argumentação a partir do modo como interior das coisas foi constituído. Inicialmente, ele surgiu simplesmente como o que está para além do sensível, que passa a ser fenômeno. Entretanto, o entendimento também quis que ele fosse algo objetivo, distinto de um mero modo subjetivo de ver a realidade. Então ele foi posto como interior das coisas. Desse modo, o interior está tanto para além do fenômeno quanto da própria consciência; pois, como se disse, esta só tem acesso ao interior através da mediação do jogo de forças, que permanece assim como um entreposto entre os dois. Fica determinado, portanto, que a consciência só tem acesso ao fenômeno e só mediante ele à verdade que está no interior. O interior não pode ser conhecido como é em si, justamente porque é desde sempre determinado como o que não está acessível em si à consciência senão apenas mediatamente.

Se o interior não pode ser conhecido, restam duas alternativas à consciência. Em primeiro lugar, "[...] ater-se ao fenômeno, isto é: tomar por verdadeiro algo que sabemos não ser verdadeiro [para preencher este vazio]" (FE, p. 104, § 146). Ou seja, como o interior não pode ser conhecido, o que resta de mais próximo da objetividade, o fenômeno, tem de preencher seu lugar. Entretanto, o fenômeno é determinado como o que não tem essência em si. Então também já está dito previamente que ele não contém a verdade que se procura.

Ou, na segunda alternativa, como o interior é o que está para além de todo conteúdo, "[...] para que haja algo nesse vazio total, que também se denomina sagrado, há que preenchê-lo, ao menos com devaneios: fenômenos que a própria consciência produz para si" (FE, p. 104, § 146). Aqui trata-se de tomar elementos que são acessíveis à consciência, que por isso são no fundo fenômenos, para preencher o vazio do interior. Enquanto antes o fenômeno era mantido como tal mas assumido como a única verdade que resta, agora ele é conduzido ao interior para ser a verdade em si que se procura nele.

Segundo o ponto de vista de Hegel, as duas situações são inaceitáveis, pois contradizem o princípio básico do interior - ser a verdade como o que está para além do que é percebido pela consciência. Na primeira situação descrita, tomando o fenômeno como tal, sabe-se que ele é algo evanescente e por isso não pode substituir a verdade mesma, que só 
está presente no interior. No caso da segunda situação, sempre que se atribui qualquer conteúdo ao interior, está-se apenas fazendo com que fenômenos assumam o lugar do suprassensível. Na verdade, nenhum conteúdo pode ser encontrado no interior, pois o fato de algo ser encontrado ali implica que se está de posse apenas do que é cognoscível, enquanto o interior mesmo é inacessível.

Nesse ponto aparentemente surge um paradoxo. Por um lado, o interior é determinado como sendo o inacessível ao entendimento. Mas, por outro, o entendimento mesmo o toma como sua verdade. Se ele é inacessível, não se pode ter ideia alguma do que seja. Mas se ele é a verdade, já tem algum significado para o entendimento e, portanto, não é mais inacessível. Esse paradoxo resolve-se ao considerar o fato de que o interior, segundo Hegel,

[...] provém do fenômeno, e esse é sua mediação. Quer dizer: o fenômeno é sua essência, e de fato, sua implementação. O supra-sensível é o sensível e o percebido postos tais como são em verdade; pois a verdade do sensível e do percebido é serem fenômeno. O supra-sensível é, pois, o fenômeno como fenômeno (FE, p. 104, § 147).

Ou seja, a verdade que o interior quer expressar não é nada mais nada menos do que o fato de que o jogo de forças, o sensível percebido, é fenômeno, algo destituído de essência própria. Então, o interior é a essência do fenômeno, ou melhor, a essência do fenômeno, no seu desvanecer, é o interior. Isso significa que não se tem acesso mesmo ao interior, a não ser mediante o fenômeno. Mais ainda, o interior só surge para o entendimento como a essência que está para além do percebido, porque o percebido mostra não ter essência em si mesmo. O interior, assim, não é uma essência a que o entendimento tem acesso. Ele representa antes o fato de que a essência do mundo objetivo não está presente nele e por isso não pode ser apreendida como algo observável empiricamente. Desse modo, o acesso que o entendimento tem ao interior é diferente do acesso que ele teria a uma verdade imediata qualquer. Na verdade, o que há no interior é apenas o que é posto pelo fenômeno como fenômeno. Ou seja, parte-se da aparência para ver o que ela necessariamente tem de pressupor como essencial justamente enquanto é aparência. Assim, o entendimento nem tem acesso ao interior enquanto tal, nem deixa de poder representá-lo, embora isso só seja possível mediatamente (através do fenômeno).

Hegel faz outra observação tentando esclarecer ainda mais a relação entre o interior e o fenômeno. A partir do modo como surgiu, o interior é a essência do fenômeno. Essa afirmação é aparentemente contraditória, pois faz equivalerem duas realidades que por definição são distintas. Quer dizer, o interior é o que está para além do mundo observável, enquanto o fenômeno é tomado justamente como esse mundo, de modo que um não pode ser o outro. Hegel retoma justamente essa posição. Segundo ele, "costuma-se dizer-se que o supra-sensível não é o fenômeno; mas, com isso, não se entende por fenômeno o fenômeno e sim o mundo sensível como a própria efetividade real" (FE, p. 104, § 147). Ou seja, o que está por trás da oposição entre fenômeno e suprassensível é a consideração de que ambos são duas realidades subsistentes e independentes uma da outra, pois ao dizer-se que duas coisas são opostas está-se afirmando que o ser de uma não é o ser da outra. Isso significa que a oposição entre suprassensível e sensível só é possível quando se negligencia o verdadeiro significado do fenômeno - ser um evanescente, algo que não é - e do próprio interior - ser a essência do fenômeno. Considerados dessa forma, que segundo Hegel é a 
adequada, ambos não podem ser opostos; pois, quando o ser de um é o outro, há identidade e não distinção. Desse modo, quem diz que o sensível não é o interior ainda não chegou ao ponto de considerá-lo na sua forma própria, o fenômeno, e por isso não pôde compreender que ele só "é" enquanto interior, ou seja, enquanto um ser que tem para além de si sua essência.

Desse modo, a partir da experiência que o entendimento fez sobre o jogo de forças, ele chegou ao ponto de considerar como verdade o interior suprassensível, que não é imediatamente acessível, mas que pode ser implementado através do fenômeno. O próximo passo, conforme a descrição hegeliana, é observar a experiência que ocorre com o próprio entendimento quando ele tenta apossar-se da verdade como um interior suprasssensível.

\subsection{A diferença universal como lei do fenômeno}

Para ter acesso à verdade, que é o interior, o entendimento tem de usar a mediação do fenômeno. O fenômeno é, assim, o modo pelo qual o interior deixará de ser um puro além vazio para ser realmente a verdade do que ocorre no mundo sensível percebido.

É importante lembrar também que o desvanecer do fenômeno surgiu a partir da tentativa, por parte do entendimento, de conceber o universal incondicionado com força, ou seja, como um ente empírico. Sendo o incondicionado, a força deveria ter em si a unidade entre o ser para si e o ser para outro, que na força foram postos como recalcamento em si e desdobramento. Mas a unidade entre os dois implica apenas o momento da força recalcada em si que precisa exteriorizar-se, assim como o desdobramento só é possível como diferenciação a partir da força recalcada, e por isso desvanece nela. Por causa desse desvanecer dos momentos da força, tentou-se considerar a diferença a partir da oposição entre força solicitada e força solicitante, como também entre forma e conteúdo. Entretanto, como ficou explícito, todas as diferenças transmudam-se umas nas outras de modo que nada de subsistente resta. Nesse ponto, o jogo de forças passa a ser considerado fenômeno. Consequentemente, a verdade que o entendimento buscava desloca-se para o interior, ou seja, está para além do fenômeno e da consciência. Nisso fica demonstrado também que a unidade da diferença (ser para si e ser para outro) é possível apenas num mundo suprassensível.

Como o mundo suprassensível é a essência do fenômeno, ele assume de imediato a forma de um interior simples e permanente. É simples porque, como essência dos momentos do jogo de forças, é o retorno ao que é condição ou fundamento de seu desvanecer. E, sendo o fundamento do desvanecer dos dois, redu-los à unidade de uma só essência. Da mesma forma, é permanente porque é posto como o que sustenta o desvanecer e que, por isso, não desvanece.

Mas o entendimento ainda não sabe o que é que permanece e que é o simples, pois o interior, na medida em que está para além do que pode ser percebido imediatamente, é ainda puramente vazio. O interior só poderá ser apreendido através de um meio termo - o fenômeno.

Na medida em que o fenômeno tem como essência o suprassensível, ele é também a forma que o suprassensível assume ao tornar-se acessível aos sentidos. Essa constatação 
parece uma mera tautologia, mas revela algo de importante: a essência posta no suprassensível está presente também no sensível, embora não na sua forma essente, mas antes como desvanecer. Tendo consciência dessa ligação entre a essência e sua aparência, torna-se possível ao entendimento encontrar o conteúdo que é indicado como essente pelo desvanecer do fenômeno.

O entendimento procura a verdade, mas ela não é acessível imediatamente. Só "o jogo de forças é imediatamente para o entendimento; porém o verdadeiro para ele é o interior simples; por isso também o movimento da força somente é o verdadeiro como algo simples, em geral" (FE, p. 105, § 148). Ou seja, o entendimento procura a verdade e sabe que ela está para além do percebido. Mas ele também sabe que este além surgiu a partir do momento em que o percebido foi tomado como fenômeno. Então ele tem consciência de que a essência que ele procura é a que é indicada pelo fenômeno no seu desvanecer. Consequentemente, cabe a ele descobrir o que deve ser essente para que o fenômeno seja uma aparência. Já se sabe que o interior é simples; pois, como essência dos momentos evanescentes no jogo de forças, ele tem de sustentar a ambos na unidade de seu ser. Então basta ver qual é o elemento que é indicado como simples pelo próprio fenômeno.

Toda essa argumentação pode ser mais bem esclarecida da seguinte forma. $O$ entendimento sabe que o que se apresenta imediatamente é evanescente, não tem essência alguma em si mesmo. Mas ao menos enquanto evanescente ele "é". Ao afirmar isso, ele toma o percebido por fenômeno e também lhe dá um fundamento que, ao mesmo tempo, não pode estar nele (nem tampouco na consciência, pelas razões já mencionadas). A questão que se coloca agora para o entendimento é saber o que é posto como essente quando o percebido evanesce. Ora, procurar a essência do fenômeno é buscar o ser em que todos os elementos evanescentes encontram a base para seu desvanecer. Isso significa que a essência do fenômeno, que deve estar no interior, é a unidade ou simplicidade que é posta no ato mesmo do desvanecer. Aliás, o desvanecer mesmo só é possível porque, ao lado do momento tomado como essencial, outro é posto e acaba assumindo o lugar do primeiro. $O$ que não desvanece, consequentemente, é o que não tem ao seu lado outro ser como sua negação, isto é, a essência determinada em seu ser simples. Com isso o entendimento já sabe sua tarefa: encontrar o que é simples no fenômeno, o que não é negado por nenhum ser outro.

Conforme se viu antes, no jogo de forças o que ocorre é a troca constante de determinações, em que cada momento considerado como essente torna-se diferente de si e, por isso, converte-se no que é por ele mesmo posto como um outro a ele oposto. É por essa razão que o jogo de força é fenômeno: nele não resta nenhuma diferença fixa, tudo é suprassumido constantemente. Nessa altura da argumentação, Hegel afirma: "por conseguinte, desvanece toda a diferença entre forças particulares que deveriam estar presentes nesse movimento, uma frente à outra, em geral, já que tinham por base apenas aquelas diferenças. Igualmente, a diferença das formas converge, junto com as duas diferenças, numa diferença única" (FE, p. 105, p. 148). No jogo de forças, cada momento deveria ser em si diferente do outro. Mas, quando invertem suas determinações, a diferença se esvai, pois desvanece o que era seu sustentáculo - a essência isolada de cada momento. A força solicitada, por exemplo, deveria ser em si diferente da força solicitante. Porém, quando se descobre que a força solicitada é antes solicitante, já que é ela que faz com que a outra 
seja o que é, sua essência de força solicitada desvanece, pois esta é agora um não ser (um outro) em relação à sua essência de força solicitante. Ou seja, enquanto a diferença tem por base a essência de cada momento ela desvanece exatamente junto com o desvanecer da essência dos momentos. Entretanto, e é isso que Hegel quer indicar, com isso não desvanece a diferença como tal, pois é só porque ela se sustenta que a diferença entre os momentos desvanece, mediante o desvanecer deles mesmos enquanto essências distintas.

Por exemplo, a força solicitada torna-se solicitante. Nisso ela se torna o que era para ela um não ser e assim deixa de lado sua diferença para com ele. Mas ela desvanece na verdade porque a diferença como universal se mantém. Enquanto ela se iguala ao que antes Ihe era diferente, ao mesmo tempo se diferencia do que a ela era igual. Quer dizer, antes era solicitada e não era solicitante. Agora passa a ser solicitante, deixando de ser solicitada. Isso significa que a diferencia está presente não só quando os momentos são distintos; mas também, o que no fundo é o mesmo, quando a diferença entre eles sucumbe, pois neste caso ainda resta o diferenciar-se de si mesmo, que faz com que a essência de cada momento oponha-se a si mesma e nisso desvaneça. Entretanto, não se trata mais aqui da diferença entre dois momentos determinados, a força solicitada e a força solicitante, por exemplo; e sim do diferenciar em geral, ou da diferença que não é esta ou aquela (singularidade) e que, por isso, é diferença universal.

Desse modo, em meio aos momentos diferentes, que sem cessar surgem, o que resta de simples e permanente no fenômeno é a diferença como universal. Isso significa, segundo Hegel, que "esta diferença como universal é, portanto, o simples no jogo da força mesma, e o verdadeiro desse jogo. A diferença é a lei da força" (FE, p. 105, § 148).

Antes Hegel tinha afirmado que o interior surgiu para o entendimento como a verdade do fenômeno por ser a essência simples e permanente que deveria estar por trás do desvanecer. Mas o interior era ainda vazio, e só poderia ser implementado através do próprio fenômeno. Agora, como se vê, chegou-se através do fenômeno justamente ao que é simples e permanente nele - a diferença universal. Ou seja, o fenômeno absolutamente cambiante mostra o que existe de simples e permanente, que está para além de seu desvanecer e é sua condição. Isso, na verdade, nada mais é do que a volta à essência de seus momentos e por isso é sua verdade. A diferença universal deve ser, portanto, a verdade procurada.

A diferença universal, como sugere Hegel, é também a lei do fenômeno. Isso se deve ao tipo de relação que ela estabelece com aquilo de que é a essência. No fenômeno tudo muda. Então, a

\footnotetext{
mudança é sua essência, mas a mudança como posta no Interior como é em verdade, e por isso nele recebida como sendo também absolutamente universal, tranqüilizada e permanecendo igual a si mesma. Ou seja: a negação é o momento essencial do Universal; ela - ou a mediação - é assim, no Universal, diferença universal (FE, p. 106, § 149).
}

O fato é que, tanto no mundo sensível percebido, quanto no mundo suprassensível, a diferença está presente. Entretanto, pelo fato de este ser a essência daquele, que é por isso sua aparência, enquanto neste a diferença apresenta-se como passagem constante de um momento a outro (desvanecer), naquele ela está como algo que não muda, que continua sempre igual a si mesmo, pois se ela se tornasse também aqui um ser outro (mudança), 
deixaria de ser essencial. $\mathrm{O}$ incondicionado surgiu pela necessidade de o universal ter em si o ser outro ou a diferença. No mundo percebido, isso faz com que surja, ao lado de cada momento da força, seu outro. Por isso, os momentos desvaneceram. A essência desse desvanecer é, portanto, a negação ou a diferença como universal. Mas, posta como um interior (como a verdade do fenômeno), ela permanece igual a si mesma, quer dizer, em relação a ela não pode haver nenhum ser outro. Desse modo, a diferença universal surgiu como o simples do jogo de forças e, portanto, é sua essência. E por ser a essência, é também sua lei, pois prevê, através de sua permanência, a mudança constante no mundo fenomênico. Ou, como afirma Hegel, a diferença "se exprime na lei como imagem constante no fenômeno instável" (FE, p. 106, § 149). 


\section{AS EXPERIÊNCIAS DO ENTENDIMENTO COM O REINO DAS LEIS}

Nesta seção, apresentar-se-á o conjunto das experiências que conduzem o entendimento da ideia de reino das leis à sua própria superação no conceito de infinitude. $O$ entendimento tenta conceber o fenômeno como desenrolar de diferenças determinadas, que obedecem a leis universais presentes no mundo suprassensível. Entretanto, a dualidade entre o caráter unitário da lei e a multiplicidade do que se quer explicar está sempre presente, impedindo que um elemento possa ser concebido como a explicação do outro. Em busca da superação dessa dualidade, o entendimento será obrigado a ultrapassar a estrutura categorial que aceita tacitamente. Nisso, encontrará a si mesmo.

\subsection{O suprassensível com o reino das leis}

O importante a observar na nova forma de o entendimento tomar a verdade é que agora a essência é considerada a base do movimento e por isso é lei. Na certeza sensível e na percepção, tratava-se apenas de essências inertes, em que a diferença não podia estar presente. Agora a diferença é necessária. A bem dizer, o movimento já tinha sido considerado na essencialidade a partir da ideia de força. Entretanto, a força deveria ser a essência do movimento como também seu desenrolar. Essa situação, por sua vez, mostrou ser insustentável, pois enquanto essência do movimento, a forma permanece igual a si mesma e a diferenciação (que é o próprio desdobrar do movimento) torna-se um outro, oposto à ela; do mesmo modo, no desenrolar do movimento, a força se diferencia de tal forma que escapa ao seu ser uno, tornando-se oposta a ele. Ou seja, no movimento mesmo não resta essência alguma. Com isso, o entendimento conclui que o movimento só pode ser tomado como essente se sua essência estiver afastada do desvanecer que é seu desenrolar. A lei, assim, é a essência do movimento, mas enquanto tal permanece igual a si mesma.

Com isso, o suprassensível fica determinado para o entendimento como "[...] um tranqüilo reino de leis" (FE, p. 106, § 149). Enquanto verdade do fenômeno, ele contém o que é simples e permanente nele - a diferença universal ou lei. Assim, as diferenças que a força deveria possuir encontram sua base, sem que isso signifique simplesmente o momento do recalcamento, como ocorria no jogo de forças. Isso porque a lei é a verdade permanente do que ocorre no fenômeno, mas não é toda a realidade, de modo que nenhuma diferença possa estar presente. Ou seja, a lei expressa apenas a essência do que ocorre no fenômeno, que é o diferenciar constante dos momentos, mas pela simplicidade desta determinação não fica excluída a diferença como tal no fenômeno. Pelo contrário, é justamente por essa base suprassensível simples, a diferença universal, que cada momento se diferencia do outro e também de si mesmo, levando adiante o movimento do aparecer. 
Mas o fato de o reino das leis tomar a diferença apenas em sua universalidade deixa sempre a este algo que não é suprassumido, isto é, que não está previsto na lei. Como afirma Hegel,

a lei está nele presente, mas não é toda a sua presença: sob situações sempre outras, tem sempre outra efetividade. Portanto, resta ao fenômeno para si, um lado que não está no interior; ou, o fenômeno ainda não está posto em verdade como fenômeno, com ser-para-si suprassumido (FE, p. 106, § 150).

É importante lembrar que o jogo de forças só foi considerado fenômeno quando mostrou não ter em si essência alguma, sendo, portanto, um puro desvanecer. Foi por isso que sua verdade teve de ser posta num além supra-sensível. Entretanto, o reino das leis, que é a implementação do mundo suprassensível, toma apenas o que é simples e permanente no jogo de forças - a diferença universal. Não considera, portanto, as diferenças específicas que surgem e desvanecem. Ora, se essas especificidades não encontram base no suprassensível, só podem estar fundadas no próprio mundo percebido. Isso significa, portanto, que o percebido não foi ainda posto inteiramente como fenômeno.

Para pôr o fenômeno inteiramente como tal, ou seja, com um suprassumido, as diferenças específicas que se dão nele têm de encontrar sua base também no suprassensível, ou seja, na lei. Mas a lei, como indica Hegel, "[...] embora tenha em si a diferença mesma, só a tem com universal, indeterminada. Porém enquanto não é a lei em geral, mas uma lei, tem nela a determinidade, e assim se dá uma pluralidade indeterminada de leis" (FE, p. 106, $\S$ 150). Ou seja, a lei em sua generalidade é incapaz de captar tudo que ocorre realmente no fenômeno. Mas o fenômeno enquanto tal tem de ter seu ser completamente suprassumido nela. Isso só é possível se ao invés de uma lei geral existir uma multiplicidade de leis. Cada lei particular, assim, suprassumiria uma parte do mundo fenomênico.

Entretanto, afirma Hegel, "[...] essa pluralidade mesma é antes um defeito: contradiz precisamente o princípio do entendimento para o qual, como consciência do interior simples, o verdadeiro é a unidade em si universal" (FE, p. 106, § 150). Essa afirmação, pois, lembra e ao mesmo tempo explicita algo de importante em relação àquilo que o entendimento toma como verdade. Essa figura da consciência, como já se afirmou, surge no momento em que a verdade passa a ser tratada como o universal incondicionado, quer dizer, como a unidade entre ser para si (identidade) e ser para outro (diferença). O entendimento tenta encontrar, consequentemente, o ser que no mundo real (distinto dele próprio) é constituído por essa unidade. O primeiro candidato foi a força. A força enquanto tal é apenas a volta a si dos momentos, mas a verdade é o incondicionado, em que a diferença também tem de estar presente. Foi esse o motivo principal que faz do mundo em que a força deveria ser a essência um mero fenômeno. Com isso, o entendimento teve de pôr a unidade entre ser para si e ser para outro para além do mundo percebido. Mas o importante é observar que esse além deveria ser a unidade entre o ser para si e o ser para outro que não pôde ser realizada pela força. Isso fica explícito no fato de que a lei é a diferença universal, que é o simples do jogo de forças, ou seja, o que permanece igual a si mesmo ou o que em relação ao qual nenhuma diferença pode surgir. Então, o suprassensível, que se tornou um reino de leis, deveria ser simples. Esse fato se expressa também no próprio modo como a lei surgiu. Diante das diferenças evanescentes, o entendimento perguntou-se qual seria sua base, já que ele 
mesmo não a possuía. A base deveria ser a diferença universal, o diferenciar constante dos momentos. Então, o que é posto como essência é algo simples, pois é em sua unidade o fundamento para todas as diferenças existentes no mundo percebido. Consequentemente, não poderia haver nele nenhuma diferença, já que ele é a volta a si de tudo o que é distinto. Mas é exatamente isso o que ocorre quando várias leis surgem para suprassumir todas as especificidades do fenômeno. A diferença é reposta na própria essência, onde não poderia haver diferença alguma. Desse modo, tentar a suprassunção total do fenômeno através de diversas leis é contradizer o próprio princípio a partir do qual a lei surgiu como o essencial do jogo de forças.

Devido a essas circunstâncias, "[...] o entendimento deve fazer coincidir as múltiplas leis numa lei só" (FE, p. 106, § 150). Ou seja, o único modo de evitar que a diferença seja inserida no interior simples é fazer com que as diversas leis sejam unificadas numa única lei. Só assim a diferença não estaria presente também aí. Hegel cita inclusive o exemplo da unificação das leis da queda dos corpos e do movimento das esferas celestes na lei da atração universal. Para ele, embora com isso se consiga manter a simplicidade do interior, perde-se a determinidade dos fenômenos específicos envolvidos, restando apenas "[...] o mero conceito da lei mesma". Pois, "a atração universal diz apenas que tudo tem uma diferença constante com Outro" (FE, p. 107, § 150). Ou seja, pela unificação das várias leis numa só, obtém-se apenas o conceito de lei como diferença universal, em que não estão contidas todas as determinidades presentes nas leis particulares que se referem a aspectos mais precisos do real ${ }^{15}$. Embora a lei da atração universal estabeleça a relação constante que há entre os elementos do fenômeno - a diferença -, não determina que elementos são esses e como a relação entre eles se desenrola especificamente. A queda dos corpos e o movimento das esferas celestes guardam cada um para si um conjunto de elementos que não são comuns a ambos e que por isso têm de ser negligenciados quando surge a lei da atração universal como a verdade dos dois âmbitos específicos.

Isso significa, por sua vez, que a lei em sua unidade, aqui representada pela atração universal, opõe-se às leis determinadas. Isso pode ser explicitado a partir de duas considerações. Em primeiro lugar, a unificação da lei implica necessariamente o abandono de aspectos particulares do fenômeno, de modo que a lei determinada que compreendia esses aspectos torna-se algo distinto do que é tomado como lei depois da unificação. Mas, em segundo lugar, essa diferença é também oposição, pois a lei determinada é em si algo oposto

\footnotetext{
${ }^{15}$ Essa problemática, como aliás também outras presentes na Fenomenologia, remetem à relação que se estabelece entre a compreensão e a extensão de conceitos. O conceito homem, por exemplo, é menos extenso do que o conceito de animal, entretanto por ele está mais bem compreendido seu conteúdo do que no outro caso. Ou seja, quanto mais universal é um conceito, menor é o grau de determinação de seu conteúdo. No caso da lei, reduzindo-a a uma unidade, tem-se a simplicidade total do suprassensível, mas perde-se sua determinidade. Ou seja, obtém-se um conceito que é capaz da extensão máxima, suprassumindo toda diferença, mas que por isso mesmo tem de deixar de expressar tudo de específico que está contido nele. Por outro lado, com leis diversas a compreensão completa do fenômeno é alcançada, mas nisso se perde a extensão ou universalidade do conceito, que é o mesmo que a simplicidade exigida pelo entendimento.
} 
à lei una. Isso porque as leis específicas, na tentativa de suprassumir todos os aspectos do fenômeno, tornam o que é, a essência, algo múltiplo, enquanto a lei universal determina que a base do fenômeno é simples, em que as diferenças não podem estar presentes. Mais precisamente, a lei universal é o momento em que a diferença é tomada como algo simples, de tal forma que não surge ao lado dela outro ser, enquanto nas leis determinadas o que está presente é justamente a diferença efetiva, ou seja, o coexistir de diversas essencialidades.

$\mathrm{Na}$ verdade, trata-se da mesma oposição, anteriormente mencionada, entre o ser para si e o ser para outro. Enquanto naquele o que está determinado é a unidade, ou seja, o desvanecer das diferenças enquanto diferentes, ou a volta das mesmas à essência (unidade); nesta, o que está posto é a expansão efetiva das diferenças, em que cada uma opõe-se a todas as demais. Aliás, é importante observar como o movimento desdobrou-se a partir dessa situação. A força tinha de ser a unidade entre os dois momentos, mas não pôde porque nisso seria apenas o ser para si. A lei surge, de certa forma, para cumprir esse papel de ser a essência que está na base dos dois momentos entre si opostos. Ela tem a vantagem de estar para além da esfera empírica, o que evita a eliminação das diferenças no momento da unidade simples, na medida em que, no fenômeno ao menos, elas ainda permanecem. Entretanto, ressurge o problema que já estava presente na percepção, como também na consideração da força enquanto tal (recalcada em si). É que o universal simples, o ser para si, é indeterminado. Embora seja em si a base da diversidade, não a expressa em todas as suas especificidades. Mas o reino das leis deveria fazer isso, pois foi tomado como a essência do fenômeno. Este enquanto tal é, por sua vez, um si apenas um puro desvanecer, de tal forma que nenhum elemento pode encontrar subsistência nele. Porém, como o suprassensível em sua simplicidade não suprassume tudo o que está contido no fenômeno, acaba tendo de restar a ele algum tipo de efetividade, o que não é possível pela sua própria natureza. Isso mostra que o que está em jogo é novamente o problema da determinação do universal. Enquanto verdade do sensível percebido, a universalidade do reino das leis tem de expressar tudo que ocorre nele. Como isso não é possível apenas pelo momento do ser para si, é preciso inserir no reino das leis novamente o ser para outro, isto é, a multiplicidade ou a diferença. E isso se expressa agora na forma de uma diversidade de leis. Criam-se, assim, novamente duas exigências opostas intrínsecas ao próprio ser daquilo que o entendimento quer tomar como essência.

Mas essa oposição não diz respeito apenas à relação entre as leis determinadas e a lei universal. Como afirma Hegel, "[...] a determinidade de que se falava é apenas momento evanescente, que não pode mais apresentar-se aqui como essencialidade, pois só está presente a lei como o verdadeiro; porém o conceito de lei se voltou contra a lei mesma" (FE, p. $107, \S 151)$. Na medida em que a lei surgiu como o que é simples no fenômeno, desde o início já está posto que ela não pode ser uma lei determinada, pois isso só se cumpriria pela diferenciação de elementos, que é justamente o oposto da simplicidade. Como consequência imediata, a determinação ou o conteúdo próprio da lei é excluído dela e tem de ser encontrado no fenômeno. Entretanto, o fenômeno é, como ficou explícito no jogo de forças, um evanescente. Por isso, a lei mesma tem de ser a suprassunção do que está contido no fenômeno na forma evanescente. Ou seja, a lei mesma tem de ser determinada. 
Consequentemente, o conceito de lei, segundo o qual ela é o simples do fenômeno, opõe-se à lei efetiva, que tem de ser determinadamente a verdade do fenômeno.

Para Hegel, essa situação decorre do fato de que "é justamente na lei que a diferença é captada imediatamente e acolhida no universal; mas com isso [também] um subsistir dos momentos cuja relação ela exprime como essencialidades indiferentes e em-si-essentes" (FE, p. 107, § 151). A oposição entre os dois aspectos na lei, mencionada acima, tem sua origem na própria essência da lei. Enquanto diferença universal, ela é por um lado a volta àquilo que é simples no transmudar constante das diferenças. Mas esse simples, que é o próprio diferenciar constante ou universal, supõe elementos que se diferenciam. Ou melhor, só há diferença se há elementos que entre si são distintos. Isso significa que a própria diferença, mesmo como universal, supõe alguma determinidade. Dessa forma, quando a diferença universal é posta, também surgem os momentos entre si distintos, cada um tendo seu ser fundado em si mesmo, independentemente do outro.

Entretanto, como separadamente os lados da diferença são evanescentes, também está posta a necessidade do retorno ao que é simples. Por isso, segundo Hegel,

o conceito puro da lei, como atração universal, deve entender-se em seu verdadeiro sentido, de que nesse conceito como no Simples absoluto, as diferenças que ocorrem na lei como tal retornam de novo ao interior, como unidade simples; esta unidade é a necessidade interior da lei (FE, p. 107, § 151).

Ou seja, a lei, como diferença universal, põe os elementos distintos como distintos e, ao mesmo tempo, afirma que eles só "são" como algo simples, como uma unidade que não está em nenhum dos elementos, mas que simultaneamente é o interior de ambos. Assim, com o conceito de lei fica estabelecido, sobretudo, a relação necessária que há entre os elementos distintos e o interior simples. O interior simples é a diferença universal que se expressa na forma de diferenças efetivas. Estas, por sua vez, só são reais na medida em que se baseiam num interior simples. A essa ligação, como se viu, Hegel dá o nome de "necessidade interior da lei", ou seja, a necessidade de que as diferenças mostrem no seu desvanecer (no mundo percebido) que têm sua base na simplicidade do interior, e que o interior seja a verdade cuja manifestação são as diferenças percebidas.

\subsection{A duplicação da lei e o retorno à força}

De todo modo, segundo Hegel, "a lei está portanto presente de duas maneiras: uma vez como lei, em que as diferenças são expressas como momentos independentes; outra vez, na forma do simples Ser-retornado-a-si-mesmo, que de novo pode chamar-se força" (FE, $p$. 107 , § 152). Surge para o entendimento, assim, uma nova distinção a partir da qual ele pretende apossar-se da verdade a partir das duas exigências que ele percebe nela: a determinidade ou diferenciação e a simplicidade. A lei efetiva, enquanto verdade do fenômeno, tem de suprassumir os elementos presente nele, ou seja, tem de ser determinada. Mas também há a necessidade de que os elementos distintos tenham uma base, que só pode ser uma unidade simples. Então, o que está posto é a necessidade do movimento pelo qual as

diferenças retornam a si mesmas. Esse movimento entre a unidade e a multiplicidade, como 
se viu antes, é a força. Com isso, enquanto as diferenças efetivas cabem à lei, a volta à unidade é a força.

Este é o novo modo de o entendimento tomar a verdade. A lei garante as diferenças em si essentes que lhe dão conteúdo, enquanto à força cabe a volta à unidade. Entretanto, as duas estruturas não estão desvinculadas. Na verdade, elas só são o essencial porque mantêm entre si um vínculo estreito, representado pelo que Hegel chamou de necessidade interior da lei. Ela é que faz com que as diferenças não desvaneçam, nem a essência se torne vazia. Isso porque por ela está posto que as diferenças devem retornar ao interior simples e que este é o voltar a si (à essência) dessas diferenças. Trata-se, portanto, de duas estruturas que isoladamente não cumprem aquilo que é exigido da verdade como interior, ser simples e suprassumir o fenômeno, e que por isso são o verdadeiro na medida em que guardam cada uma em relação à outra um laço de necessidade.

Isso mostra que aquilo que o entendimento toma por verdade não é nada mais do que o resultado da experiência anterior. Ou seja, ele apenas tenta considerar o suprassensível, que é para ele o verdadeiro, a partir das exigências que se mostraram essenciais no que se refere à verdade: ser o universal simples e determinado. As diferenças enquanto tais estão presentes nas leis efetivas e a simplicidade na forma de força. Enquanto fenômeno, a essência do percebido tem de estar no interior. Então, é preciso que o interior preveja o que ocorre no fenômeno através de leis determinadas. Mas as diferenças, como também mostrou o jogo de forças, só são efetivas quando têm uma base, e esta é o próprio diferenciar universal. Então nelas já está posto como necessário o retornar a esse interior simples. Dessa forma, pelo próprio modo como a experiência se desenvolveu, está posto o que é a verdade: as diferenças na lei, cujo ser é a força simples; ou a força simples, cuja determinação é a diferença contida na lei. As duas exigências são simplesmente mantidas na forma como se apresentaram, isto é, simultaneamente necessárias.

O essencial para o entendimento é, assim, encontrar a força e a lei em seu vínculo necessário, pelo qual as diferenças, ao mesmo tempo em que estão presentes nesta, têm de retornar à simplicidade daquela. Para verificar como isso ocorre, Hegel descreve a experiência do entendimento na consideração da eletricidade e do movimento.

A eletricidade em seu ser simples é a sua força. Mas ela tem a lei de apresentar-se como negativa e positiva. No caso da lei, o vínculo entre seus dois elementos é nítido: se o positivo é posto, também o negativo o é, "[...] porque o positivo é somente como relação a um negativo, ou seja, o positivo é nele mesmo a diferença de si mesmo, como também o negativo" (FE, p. 108, § 152). Este aspecto diz respeito ao conteúdo do que é chamado de eletricidade. Pelo fato de o negativo e o positivo serem interdependentes, um não pode ser sem o outro. Ou melhor, um só é mediante o outro. Então, está indicado, como ocorreu no jogo de forças, que o ser de ambos é o interior simples, que aqui é denominado de força.

Parece, portanto, que a necessidade interior da lei, segundo a qual as diferenças têm de retornar à unidade, foi realizada. Entretanto, há outro aspecto que deve ser levado em conta. Embora o negativo e o positivo mostrem ter um vínculo necessário com a eletricidade simples, "[...] não é necessário em si que a eletricidade enquanto tal se divida assim. Como força simples, é indiferente diante de sua lei de ser como positiva e negativa" (FE, p. 108, § 152). Ou seja, embora o negativo e o positivo indiquem que são constituídos a partir de uma 
unidade fundamental, não está determinado nesse ser simples que ele tem de dividir-se nos dois elementos citados.

Aparentemente essa argumentação não faz muito sentido, já que não se pode compreender o que é a eletricidade sem considerar sua existência como negativo e positivo. Nesse caso, estar-se-ia autorizado a dizer que na verdade há sim uma relação necessária entre a eletricidade simples e a divisão contida na lei, na medida em que tal divisão seria posta como condição da existência da eletricidade. Entretanto, Hegel revela um ponto de vista ainda mais radical. Mesmo tomando como definição de eletricidade ser na forma de positivo e negativo, "[...] naquela definição não está contida a necessidade de sua existência: ela, ou é porque a encontram, logo não é nada necessária, ou então, sua existência é por meio de outras forças; logo, sua necessidade é uma necessidade externa" (FE, p. 108, § 152). O ponto fundamental, portanto, é que, embora a existência da força só seja possível na forma de positivo e negativo, não está determinado nela mesma a necessidade de existir. Ou seja, mesmo que a força esteja presente realmente e nisso seja como positivo e negativo, isso não significa que em sua simplicidade está posta a necessidade de que ela venha a ser.

O fato é que só se pode dizer que algo é necessariamente existente por comprovação empírica ou por dedução a partir de outra lei. Mas o que se está investigando é se há ou não necessidade, a partir da eletricidade simples, de ela dividir-se em positivo e negativo. Ora, já se sabe que ela só pode existir sob essas duas formas. Então, se existe, está dividida em positivo e negativo. Entretanto, não é necessário que ela mesma exista. As provas de que existe, a comprovação empírica e a dedução a partir de outra lei, tornam evidentemente necessário também que ela esteja como positivo e negativo, mas como são uma outra fonte de necessidade, distinta da própria força em questão, não comprovam que a eletricidade tem de necessariamente dividir-se nos elementos presentes na lei (o positivo e o negativo).

A questão toda é o seguinte. A lei tem de ser, para o entendimento, algo simples e determinado. Mas como os dois são opostos, não podem compor o mesmo ser. Então, o aspecto da determinidade, em que estão compreendidas as diferenças que se apresentam no fenômeno, é deixado à lei mesma; enquanto a simplicidade, em que as diferenças voltam à unidade simples, é tratada novamente como força. Mas estas duas estruturas não podem ser entre si indiferentes, pois ficou demonstrado na experiência com o jogo de forças que as diferenças, que agora estão compreendidas na lei, não se sustentam em si mesmas e por isso têm de estar ancoradas numa base simples; assim como a simplicidade, fixada agora como força, só é a essência do fenômeno se suprassume seus elementos, o que significa que ela mesma tem de mostrar que as diferenças da lei são expressões de sua essência. Em outras palavras, é preciso que as diferenças contidas na lei apontem necessariamente para a força como sua essência simples e que esta necessariamente se desdobre nas diferenças da lei.

No caso da eletricidade, o positivo e o negativo (a lei) apontam para um interior simples. Entretanto, na eletricidade como tal não está dito que ela se diferencia necessariamente nesses dois elementos. Ela só existe nesse modo determinado, mas não existe necessariamente a partir de si mesma. A necessidade de sua existência, que implicaria a diferenciação em positivo e negativo, não pode ser deduzida dela mesma, o que seria necessário, pois o que deve ser mostrado é que a força não pode ser sem a lei, mas antes apenas da experiência empírica ou de outra lei. Com isso, segundo Hegel, fica demonstrado 
que o vínculo necessário que o entendimento procurava entre a lei e a força não se concretiza em relação à eletricidade, ao menos no que se refere ao caminho que vai da força à lei. Mas há também outro caso a ser considerado, segundo Hegel, como segue.

\begin{abstract}
$\mathrm{Na}$ lei do movimento, por exemplo, é necessário que esse se divida em tempo e espaço, ou também em distância e velocidade. Sendo apenas a relação entre esses momentos, o movimento como universal está, sem dúvida, dividido em si mesmo; mas então essas partes, tempo e espaço, distância e velocidade, não exprimem nelas sua origem [comum] do Uno: são indiferentes entre si. O espaço é representado como se pudesse ser sem o tempo; o tempo, sem o espaço; a distância sem a velocidade pelo menos; assim como suas grandezas são indiferentes entre si, já que não se relacionam como positivo e negativo e portanto não estão ligadas uma à outra através de sua essência (FE, p. 108-9, § 153).
\end{abstract}

Como se pode ver, a problemática aqui gira em torno da segunda via de necessidade, que vai da lei à força. O movimento, conforme afirma Hegel, é apenas a relação entre distância e velocidade ou entre tempo e espaço. Logo, está explícito nele mesmo a necessidade de ele apresentar-se dividido nesses elementos. Entretanto, devido justamente a essa situação, que tem em si a vantagem de tornar necessário o desdobramento da força em lei, o movimento reduz-se às diferenças presentes nesta. Ou seja, tempo e espaço, ou velocidade e distância não mostram o vínculo necessário, o ser por meio do outro, que faria com que a verdade de ambos fosse posta como um interior simples, o movimento. Tempo e espaço, assim como distância e velocidade, podem ser tomados distintamente, como entidades autônomas. Assim, agora fica evidente que a necessidade interior da lei, também sob o aspecto da volta das diferenças à unidade simples, não é encontrada na realidade.

\title{
4.3 A indiferença entre lei e força e o explicar
}

"Assim [conclui Hegel], nos dois casos, a diferença não é nenhuma diferença em si mesma; seja que o universal, a força, é indiferente em relação à divisão que está na lei; ou seja, que as diferenças, partes da lei, são indiferentes umas em relação às outras" (FE, p. 109 , § 154). A multiplicidade que está na lei é indiferente à força, assim como a força é indiferente à divisão que ocorre na lei. Para entender como é decisiva essa conclusão para o ponto de vista que o entendimento adotou a respeito da verdade, basta lembrar que ela foi posta como um interior simples. É verdade que as diferenças específicas também tiveram de ser consideradas, afinal esse interior deveria conter também toda a verdade do fenômeno. Mas, como o interior simples contrasta com as diferenças específicas, teve de se considerado à parte, como o retornar das diferenças à unidade, isto é, como força.

As diferenças, por sua vez, permaneceram como lei. Entretanto, para que essa fosse a expressão adequada da realidade, tanto as diferenças na lei deveriam levar à unidade simples, através do ser por meio do outro (mútua dependência e, portanto, base numa essência única), quanto a força deveria revelar seu ser determinado como lei. Isso porque, só assim a diferença entre as duas esferas seria mantida, ao mesmo tempo em que o ser específico de cada uma. 
A força simples põe as diferença da lei como algo outro em relação a ela, e vice-versa. Mas nisso também está posto que a força só "é" na medida em que os elementos distintos na lei deixam de ser distintos, quer dizer, retornam à unidade. Da mesma forma, a lei só "é" se, da simplicidade da força, desdobram-se diferenças. Como foi possível encontrar casos que desmentem as duas exigências, ou seja, em que a lei não retorna à unidade da força nem esta desdobra-se nas diferenças da lei, fica explícito que entre elas há antes uma relação de indiferença e não a de passagem de uma à outra, necessária para que se tenha uma verdade ao mesmo tempo simples e determinada.

O que cria certa dificuldade de compreensão no modo como Hegel expõe a questão é a afirmação de que, se a relação entre força e lei é de indiferença, então entre elas não há diferença alguma. Aparentemente, seria preciso concluir o contrário. Isto é, se a força não aponta para a lei, nem esta para a força, então as duas são independentes, subsistentes em si e, portanto, diferentes.

Entretanto, a diferença tem aqui um sentido mais radical. $O$ diferente é o ser outro, o oposto. A força é diferente da lei se se opõe a ela. Mas, ao menos aparentemente, uma coisa não precisa ser oposta a outra para ser diferente. Diz-se, por exemplo, que uma árvore é diferente de uma casa, sem contudo considerar que sejam opostas. Aliás, no fundo é esse mesmo sentido de diferença que está por trás da hipótese, mencionada acima, de que, se a força e a lei são independentes, devem ser tomadas como diferentes, ao contrário do que afirma Hegel, que deduz da indiferença a ideia de que entre elas não há diferença alguma. No exemplo, casa e árvore são tomadas como seres que possuem, enquanto singulares, essencialidade própria. E é justamente por isso que são diferentes. O ser de uma, na medida em que está nela isoladamente de tudo mais, é um outro ser em relação à outra. Entretanto, pelo espírito deste trabalho, é preciso seguir a exposição hegeliana e explorar melhor o próprio sentido que o conceito de diferença adquire para o autor.

Desde o início do capítulo sobre o entendimento, ele toma a diferença como o momento do ser para outro, que é oposto ao ser para si. Esta é a relação que um ser qualquer tem consigo mesmo, isto é, é o momento da identidade. Mas a identidade de um ser consigo mesmo não diz o que o ser é. A determinação do ser depende de tudo aquilo que ele nega ao ser ele mesmo. Então, o ser não pode permanecer apenas no momento do ser para si. É preciso que ele se distinga de outro. Esse é o momento do ser para outro, que surgiu ainda no perceber. Contudo, nesse momento ele era dissociado do ser para si. O entendimento surge exatamente quando a consciência se dá conta de que, na medida em que a determinação do objeto depende de sua relação para com outro, a própria identidade do objeto consigo mesmo tem de estar unida à diferença (ser para outro).

Isso significa que na verdade há duas diferenças envolvidas. Em primeiro lugar, aquilo que comumente, como na hipótese acima, chama-se de diferença: a simples distinção entre elementos. Em segundo lugar, a diferença que está na base desses elementos distintos: a distinção entre ser para si e ser para outro. O problema é que o primeiro modo de tomar a diferença é inadequado, pois baseia-se na ideia de que os seres singulares são subsistentes por si mesmos, independentemente de tudo mais. Ideia que já foi evidenciada em seus paradoxos no capítulo sobre a certeza sensível. A diferença, considerada de modo adequado, surge no momento em que o universal, a coisa de muitas propriedades que veio a ser a 
essência a partir da certeza sensível, determina-se. Isso porque nesse momento as propriedades são evidenciadas no seu ser distinto. Mas não são distintas enquanto elementos isolados independentes, pois isso as reduziria novamente a seres meramente visados. A diferença entre elas surge a partir do desdobramento do universal simples. Essa é a fonte de toda diferença e é na verdade o próprio movimento da força: o desdobramento a partir de um ser recalcado em si. O universal simples é o momento da essência, enquanto o desdobramento é o momento da determinação ou da diferenciação. Isso significa que um momento não pode ser sem o outro. As diferenças que surgem no momento da diferenciação só são possíveis na medida em que são sustentadas pela essência que está no ser para si. Isoladamente não subsistem. Mas a diferenciação ou desdobramento é um oposto em relação ao ser para si (universal simples), pois neste o que se tem é a igualdade consigo mesmo do objeto enquanto naquele está presente uma multidão de diferenças. Então, a diferença fundamental é a oposição entre ser para si e ser para outro. É essa a situação que está por trás da afirmação de que a diferença é oposição. A diferença é o momento oposto ao do ser para si, quando, do recalcamento em si, as diferenças se expandem.

No caso específico que se está analisando, a relação entre força e lei, esta é o momento da diferenciação, do ser para outro, enquanto aquela é o ser para si. Na verdade, o interior, a diferença universal como lei, surgiu como o simples do fenômeno, ou seja, como ser para si. Mas, como verdade do fenômeno, nele tinha de estar a determinação ou a diferenciação. Como esses momentos são opostos, pois um é simples e o outro é múltiplo, tiveram de ser distintos. O ser para si, ou a volta à unidade das diferenças, foi tratado como força, enquanto o momento das diferenças coube à lei. Era essencial, entretanto, que ambos mantivessem entre si uma relação necessária, ou seja, que a força se desdobrasse necessariamente em lei, e esta mostrasse ter sua essência na força.

Isso é evidente a partir da própria ideia de universal incondicionado, que é o critério de verdade para o entendimento. Segundo o que está determinado por ele, a essência só pode ser a unidade entre ser para si e ser para outro, ou a identidade tem de ter em si mesma a diferença. No caso da lei e da força, isso não ocorreu. A força pode ser sem a lei e vice-versa. Isso significa que elas não são diferentes no sentido mencionado acima. Uma não é o ser oposto de outra. A lei não mostra ser o desdobramento da força, assim como esta não revela ser a volta à unidade das diferenças contidas na lei. Ou seja, elas não mantêm entre si a relação de ser para outro e ser para si, que é a diferença mesma. Consequentemente, a diferença que o entendimento pensava existir entre elas desvanece.

Mas se poderia ainda dizer que uma não é a outra, e que por isso elas são distintas, mesmo não sendo opostas. Entretanto, não tem sentido falar em diferença, nesse contexto de argumentação, sem falar em oposição entre ser para si e ser para outro, pois é somente essa relação que pode sustentar os elementos distintos. Quando se afirma que força e lei são distintas mesmo uma não sendo o oposto da outra, está-se supondo tratar-se de essências fixas, fundadas em si mesmas. Mas isso é impossível, conforme mostrou a experiência da certeza sensível e da percepção. Então, o que Hegel quer afirmar é que uma não tem a outra como o diferente necessariamente, ou seja, a força não se opõe a si mesma como lei nem esta como força. Mas as duas também não são essencialidades fixas, cada uma fundada em si mesma, pois é só pela unidade entre ser para si e ser para outro que há ser. 
Consequentemente, se não se tratam de duas essências distintas, nem da oposição entre a simplicidade do universal e a multiplicidade de elementos distintos; o que se pode concluir, conforme Hegel, é que elas simplesmente não são diferentes.

Por outro lado, essa conclusão tem de ser contrastada com os princípios daquilo que foi estabelecido como verdade. Não há diferença entre força e lei. "Mas [afirma Hegel] o entendimento tem o conceito dessa diferença em si, justamente porque a lei, de uma arte, é o interior, o em-si-essente; mas é, ao mesmo tempo, o que é distinto nele" (FE, p. 109, § 154). Ou seja, o entendimento está agora entre um paradoxo. Ele sabe que não pode recuar diante do fato de que a verdade é a lei que se apresenta sob o duplo aspecto, que justamente por ser duplo tem de ser cindido entre a lei mesma e a força, de ser o conjunto das diferenças que se manifestam no fenômeno e o simples dele. Mas agora o entendimento também sabe que esse duplo aspecto não está cindido na lei mesma, ou melhor, que na lei o lado da força não é diferente do lado dela mesma enquanto determinada, e vice-versa. Consequentemente, segundo Hegel, "que esta diferença seja uma diferença interna, está dado no fato de ser a lei uma força simples, ou ser com conceito dessa diferença, portanto, uma diferença de conceito. Mas essa diferença interna por ora recai exclusivamente no entendimento; não está ainda posta na Coisa mesma" (FE, p. 109, § 154). É certo que a lei internamente tem de ter os dois momentos, a simplicidade e as diferenças. Entretanto, nela mesma esses elementos não estão distintos. Portanto, a diferença que é necessária na lei, mas não se apresenta nela mesma diz respeito apenas a seu conceito. "É" ela mesma, já que é sua verdade, mas não nela mesma. A distinção deve pertencer, assim, somente ao entendimento.

Com isso, há agora uma dissonância entre o que a coisa é e o modo adequado de considerá-la. Quer dizer, a diferença é necessária na coisa para ela ser a verdade do entendimento, mas ao mesmo tempo não está presente nela como tal. $O$ entendimento descreve seu objeto a partir do que ele toma por necessário, mas ao mesmo tempo tem de afirmar que isso diz respeito só ao modo de concebê-lo, ou seja, ao seu conceito, e não a ele enquanto realidade distinta. Ou, como afirma Hegel, a lei e a força "são diferentes, sem dúvida; mas se exprime ao mesmo tempo, não serem diferença nenhuma da Coisa mesma, e assim são logo de novo suprassumidos. Esse movimento se denomina explicar" (FE, p. 109, § 154). A realidade é concebida pelo entendimento a partir da diferença entre a força, o lado da essencialidade, e a lei, o lado da determinação. A necessidade dessa distinção, entretanto, baseia-se simplesmente no conceito e não no real. A coisa é decomposta em seus elementos constituintes. Mas isso só diz respeito a ela enquanto objeto do entendimento; por isso é um mero explicar, um movimento de palavras, não de entes reais (imediatos).

Para explicitar esse modo de o entendimento conceber a realidade, Hegel cita o exemplo do raio, como segue.

O evento singular do raio é apreendido com universal e esse universal, enunciado como a lei da eletricidade - a explicação assim abarca a lei condensando-a na força, como a essência da lei. Está portanto essa força de tal modo constituída que ao exteriorizar-se surgem eletricidades opostas, que tornam a desvanecer, uma na outra. Quer dizer: a força está constituída exatamente como a lei: diz-se que ambas não são, em nada, diferentes (FE, p. 109-10, § 154). 
O que é observado no raio é a ação da eletricidade positiva e negativa, isto é, a lei. Isso significa que seu fundamento simples, a força, é a eletricidade como tal, em que o positivo e o negativo não são diferenciados. Entretanto, o próprio fundamento é tratado como lei da eletricidade, em que estão presentes positivo e negativo. Diz-se que a eletricidade como tal é constituída dessa forma, ou seja, como positivo e negativo. A força e a lei são distintas pelo entendimento, mas ao mesmo tempo são tomadas como não distintas na coisa mesma.

Isso é exatamente o que ficou determinado a partir da conclusão de que na eletricidade simples não está posta a necessidade do desdobramento em eletricidade negativa e positiva. O fato é que as duas se dão juntas, embora uma seja simples e a outra múltipla. Se a simplicidade devesse necessariamente desdobrar-se em diversidade, então uma seria o oposto da outra. Entretanto, esse movimento de diferenciação não é necessário. As duas estão presentes sem que uma seja diferente da outra. Uma é a determinação, a outra é a essencialidade simples. Mas a determinação não é um outro em relação à essencialidade simples, assim como esta não é diferente do lado das diferenças específicas. Como as duas são postas como verdade a partir do fenômeno e como não são diferentes, ambas são a verdade ou a essência como tal e a distinção entre elas cabe apenas ao entendimento.

Com isso, segundo Hegel, "[...] o entendimento, como resulta, persiste na unidade tranqüila de seu objeto, e o movimento só recai no entendimento, não no objeto" (FE, p. 110, § 155). Ou seja, a verdade permanece inalterada. A mudança diz respeito apenas ao modo como ela é representada pelo entendimento. Entretanto, há também algo de novo, como afirma Hegel na sequência.

\footnotetext{
Nós porém nele reconhecemos justamente algo que fazia falta na lei: a saber, a mudança absoluta mesma. Com efeito: esse movimento, se o examinarmos mais de perto, é imediatamente o contrário de si mesmo: põe uma diferença que, para nós, não é diferença nenhuma; e além disso, ele mesmo a suprassume como diferença (FE, p. $110, \S 155)$.
}

A lei surgiu para o entendimento como o simples e constante do fenômeno, como diferença universal. Assim, a diferença mesma estava presente na lei, mas não como diferença efetiva, que se apresenta mesmo na mudança, e sim na igualdade consigo mesma. Em outras palavras, a diferença é o pôr o outro (ser para outro), que é o mesmo que a mudança, mas em sua simplicidade ela mesma não muda, não põe nenhum outro em relação a si mesma. Isso agora é alcançado, porque a diferença entre força e diferenças é encontrada pelo entendimento na lei, mas ao mesmo tempo o seu outro é considerado como estando também presente nela, ou seja, a identidade dos dois elementos. Na lei distingue-se o aspecto de sua simplicidade ou universalidade do aspecto de seu ser desdobrado. Mas ao mesmo tempo não há diferença alguma entre esses dois momentos. Assim, por esse meio o entendimento alcança a representação da diferença em sua efetividade, ou da diferença enquanto diferente de si próprio - a mudança absoluta.

$\mathrm{Na}$ verdade, isso já estava presente, a seu modo, no jogo de forças. Como afirma Hegel, "nesse havia a diferença entre força solicitante e solicitada, entre a força exteriorizada e a recalcada sobre si mesma. Porém eram diferenças que em verdade não eram diferenças nenhumas, e que por isso tornavam a suprassumir-se imediatamente" (FE, 110, § 155). Ou seja, trata-se do mesmo movimento, em que diferenças são postas para serem logo depois 
suprassumidas. Foi justamente por meio desse processo que o fenômeno tornou-se um evanescente, pois aí ficou explícito que nenhum de seus momentos era essencial. Como consequência, a verdade foi posta como algo para além dele, como um interior simples.

Essa exigência, aliás, está perfeitamente de acordo com a noção inicial de verdade: a unidade entre ser para si e ser para outro ou o universal incondicionado. Isso porque, segundo esse ponto de vista, no essencial tem de estar presente a diferença (ser para outro), mas como algo simples (unidade). Como no fenômeno o simples é evanescente (torna a desdobrar-se), e o próprio desdobramento em sua essencialidade nada mais é do que a simplicidade (recalcamento em si), a diferença como algo essencial teve de ser posta no suprassensível; mais precisamente, foi tratada como lei.

Mas também aqui, no reino das leis, a diferença em sua simplicidade mostrou não ser a verdade em sua plenitude. Devido a sua universalidade, não pôde captar o fenômeno em sua diversidade. Por isso, a diferença teve novamente de ser posta, como meio de a lei alcançar sua determinidade. Com isso reapareceu também a oposição entre o lado da simplicidade de lei (ser para si) e o lado de sua determinidade ou diferenciação (ser para outra). As diferenças couberam à lei e a simplicidade à força. Os dois aspectos deveriam pertencer à verdade, sendo ao mesmo tempo distintos. Entretanto, a simplicidade não põe a diferença como uma outra (o exemplo da eletricidade que não tem em si inscrita a necessidade do desdobramento como positiva e negativa), assim como as diferenças não remetem à unidade como uma outra essência (tempo e espaço que aparecem como entidades independentes). Ambas não são diferentes. Isso significa que nenhuma delas mantém-se à parte da outra, assim como ocorria no jogo de forças. A força (ser para si) é o mesmo que a lei (ser para outra). A diferença entre elas é também diferente de si mesma, de forma que elas voltam à igualdade.

Entretanto, essa consideração só é possível, segundo Hegel, porque a consciência do filósofo "[...] se transferiu como objeto ao outro lado - para o entendimento - e nele experimenta a mudança" (FE, p. 110, § 155). Ou seja, só é possível considerar a mudança, o diferenciar-se de si mesmo, tomando por objeto o entendimento mesmo, pois é nele que a diferença é posta e ao mesmo tempo é suprassumida. Em outras palavras, a mudança só está presente no entendimento, enquanto a coisa mesma permanece inerte. Por isso, só o filósofo, que é capaz de dar-se conta do que ocorre no entendimento, é capaz também de considerar a mudança, pois para o entendimento o interior continua na sua identidade consigo mesmo.

"Porém [afirma Hegel], enquanto o conceito como conceito do entendimento é o mesmo que o interior das coisas, essa mudança vem-a-ser para o entendimento como lei do interior" (FE, p. 110, § 156). Trata-se, aqui, do importante passo pelo qual o entendimento toma sua consideração a respeito da forma como a verdade é contemplada por ele como uma asseveração sobre a verdade mesma. O entendimento toma a verdade como um interior. Nesse interior, estão distintos os momentos da simplicidade e da diversidade, já que são diferentes. Entretanto, segundo a experiência do explicar, essa diferença na verdade é nenhuma. Ou seja, a força não é diferente da lei. Isso significa que o oposto é a verdade. Ou seja, o interior é verdadeiro quando passa pela mudança absoluta, em que inverte sua determinação. Assim, a consideração do modo como a verdade é apreendida torna-se uma determinação inerente à própria definição do que é a verdade. 


\subsection{A dissolução do suprassensível no mundo invertido}

Com isso, surge uma nova lei do fenômeno, segundo a qual as "[...] diferenças vêm-aser que não são diferenças nenhumas, ou que o homônimo se repele de si mesmo; e também, que as diferenças são apenas tais que não são nenhumas, e se suprassumem; ou, que o heterônimo se atrai" (FE, p. 110-1, § 156). O fenômeno apontou antes para a verdade como um interior simples, que era a diferença constante, igual a si mesma. Mas agora o entendimento sabe que esse interior é antes o oposto de si mesmo. O homônimo de que fala Hegel é justamente a situação segundo a qual a diferença é igual a si mesma. Pela descoberta de que a diferença na verdade não é diferença alguma, o homônimo difere de si mesmo, pois a diferença não permanece igual a si mesma. Ela vem a ser seu outro, em que só há a igualdade. Da mesma forma, os elementos tomados como diferentes (o heterônimo) não permanecem nela assim. Mostram ser na verdade o oposto e se atraem, ou seja, vem a ser o mesmo.

Observe-se que se trata na verdade da mesma situação, mas vista de dois aspectos distintos. A diferença enquanto tal é o homônimo e os momentos diferentes que estão nela são o heterônimo. Como a diferença não é nenhuma, tanto ela deixa de ser igual a si mesma (o homônimo se repele de si), quanto os elementos distintos nela deixam de ser desiguais (o heterônimo se atrai).

No jogo de forças, cada momento tornava-se outro em relação a si mesmo e suprassumia também essa inversão. Por isso, foi considerado um puro esvanecer. Ele foi tomado, portanto, como uma aparência, cuja essência era um interior. Ora, essência é o que "é" necessariamente, ou seja, é o que não pode ser um não ser. Consequentemente, a essência do fenômeno tem de ser o que nele permanece igual a si mesmo. Foi assim que o interior veio a ser para o entendimento diferença universal. No entanto, nem mesmo a diferença universal permanece igual a si mesma. Os elementos que ela supõe não são em nada diferentes. As diferenças na lei não são diferentes da simplicidade da força, nem viceversa. Ou seja, a diferença, na sua igualdade consigo mesma (força), deveria manter a lei como um outro no qual ela está desdobrada. No entanto, isso não ocorre. Ela não se distingue em nada de seu desdobramento. Consequentemente, ela assume uma identidade com o que deveria lhe ser oposto e passa a diferir inclusive de si mesma enquanto diferença simples.

Com isso, também tem de ser revisto o próprio conceito de lei. Inicialmente, ele se referia ao que é constante no fenômeno, a diferença. Mas agora, trata-se de uma constância de outro tipo. Como afirma Hegel, "a segunda lei, sem dúvida, é também uma lei, ou um ser interior igual-a-si-mesmo; mas é antes uma igualdade-consigo-mesma da desigualdade - uma constância da inconstância" (FE, p. 111, § 156). Enquanto pela primeira lei o simples e igual a si mesmo no fenômeno era posto como sua verdade, agora é justamente o oposto que deve sê-lo. A lei, que representa a constância (o que permanece, o essente, o que não pode não ser), não toma mais como conteúdo a igualdade consigo mesma. Pelo contrário, agora o que é constante é antes o desigual.

$\mathrm{Na}$ verdade, o que é posto agora como interior é o mesmo que já estava presente no jogo de forças. Nele, como afirma Hegel, "[...] o homônimo, a força, se decompõe numa 
oposição que primeiro se manifesta como uma diferença independente, mas que de fato demonstra não ser diferença nenhuma" (FE, p. 111, § 156). A força recalcada em si punha o desdobramento como outra essência. Entretanto, ela mesma deveria ser esse desdobramento. Da mesma forma, a força exteriorizada era o oposto do recalcamento, mas não era mais do que ele mesmo. Cada momento diferente era diferente também de si mesmo e se convertia naquilo que deveria ser seu oposto. Agora esse movimento deixa de ser apenas uma aparência para ser a própria essência do interior.

Para Hegel, "[...] só com essa determinação a diferença é interior, ou diferença em-simesma, enquanto o igual é desigual a si, e o desigual é igual a si” (FE, p. 111, § 157). No primeiro modo como a lei foi tomada, a diferença estava nela apenas como algo simples, igual a si mesmo. Ou seja, não era a diferença efetiva, pois ela mesma não se tornava o oposto de si. Com a segunda lei, a diferença é diferente também de si mesma e assim é inserida como tal, em sua efetividade, no interior. E, segundo Hegel,

\footnotetext{
esse segundo mundo supra-sensível é dessa maneira um mundo invertido; e na verdade, enquanto um lado já estava presente no primeiro mundo supra-sensível, é o inverso desse primeiro. Com isso, o interior está completo como fenômeno. Pois o primeiro mundo supra-sensível era apenas a elevação imediata do mundo percebido ao elemento universal; tinha seu modelo nesse mundo percebido, que ainda retinha para-si o princípio da mudança e da alteração. O primeiro reino das leis carecia desse princípio, mas [agora] o adquire como mundo invertido (FE, p. 111-2, § 157).
}

O primeiro mundo suprassensível tinha em si a diferença em sua igualdade consigo mesma. No segundo mundo suprassensível, ela está presente como diferença mesma, em que o oposto do primeiro mundo torna-se a verdade. Por isso, comparado com o primeiro, este segundo mundo suprassensível é um mundo invertido, ou seja, seu conteúdo determinase pela inversão do que estava posto no primeiro mundo. Por esse passo, por sua vez, o suprassensível é capaz de abarcar tudo o que estava posto no fenômeno. Pelo primeiro suprassensível, o fenômeno pode ser representado como tal, quer dizer, como um aparecer. Entretanto, ainda restava para ele algo que não podia ser posto como interior - mudança mesma, a diferenciar-se de si mesmo dos momentos da força. Pela diferença como universal, a lei previa o transmudar dos momentos: o solicitar que diferenciava de si mesmo tornando-se ser solicitado, e vice-versa. Entretanto, aí não estava posta a mudança mesma, como tornarse outro a partir de si mesmo, pois o interior permanecia na sua igualdade consigo mesmo. Em outras palavras, a diferença estava no interior, mas não como diferença e sim como identidade. A diferença mesma só estava presente no fenômeno, pois só nele o igual a si mesmo se tornava diferente e as diferenças voltavam à igualdade. O mundo invertido não é nada mais do que a diferença efetiva posta também no interior. Por isso mesmo é invertido, quer dizer, é o tornar-se outro do que está no interior (a diferença em sua simplicidade).

É interessante perceber o tipo de argumentação que Hegel desenvolve aqui. Ele parte ideia de que há duas exigências a serem cumpridas pelo interior. Em primeiro lugar, ser o simples, o que permanece no fenômeno. Em segundo, suprassumi-lo completamente. Essas duas exigências são contraditórias; pois, enquanto a primeira supõe uma unidade indiferenciada, a segunda só é possível através de diferenças específicas. A saída foi, então, deixar a simplicidade à força e as diferenças à lei, como dois lados ligados entre si 
necessariamente. Na verdade, esse vínculo de necessidade é posto por cada um dos lados. A força só é simples como retornar a si das diferenças na lei, e estas só podem existir como desdobramento de uma unidade simples, pois, se tomadas como independentes, suprassumem-se mutuamente fazendo desvanecer toda essencialidade. Nessa estrutura, a diferença simples restaria na força e as diferenças específicas seriam integradas na lei. Assim, tanto a força permaneceria na sua igualdade consigo mesma, quanto as diferenças estariam presentes. Para isso é essencial que ambas permaneçam como diferenças, uma o oposto da outra. Só enquanto oposta à lei a força é igual a si mesma, assim como a lei só é igual a si mesma como oposta àquela; pois é justamente nessa situação de oposição que cada uma ganha sua determinação própria.

Entretanto, não foi isso que ocorreu. No caso da eletricidade, a força não mostrou ter em si a necessidade de que o seu outro fosse a lei enquanto positivo e negativo. Da mesma forma, no caso do movimento, espaço e tempo não mostraram ser um desdobramento cujo oposto seria uma unidade simples. Força e lei, assim, não são diferentes. Elas não têm em si a determinação de serem o oposto uma da outra. Ora, se é graças a essa oposição necessária que elas determinavam-se mutuamente, então, junto com o desvanecer da oposição, esvanece também a identidade de ambas. Ou seja, cada uma é também o oposto de si mesma. A verdade interior é, assim, o oposto do que estava determinado no primeiro mundo suprassensível. Essa inversão significa antes de tudo que o igual a si mesmo é também o oposto de si mesmo, pois é neste oposto que ele mesmo encontra sua determinação essencial. Da mesma forma, como aquilo a que ele se opõe é sua determinação essencial, passa a ser ele mesmo.

Hegel dá exemplos dessa estrutura. Segundo ele, "em momentos determinados, o resultado será este: o que na lei do primeiro mundo era doce, nesse Em-si invertido é amargo, e o que naquela lei era negro, nessa é branco" (FE, p. 112, $\S 158$ ). Ou seja, pelo mundo invertido a verdade passa a ser buscada como o oposto do que é determinado pelo primeiro suprassensível. Isso parece estranho, pois a inversão que foi sugerida inicialmente não parece conduzir a essa situação. O entendimento sabe que a diferença que deveria existir entre a lei e a força no mundo suprassensível não é diferença alguma. Isso é o explicar, que representa um movimento que não se apresenta na coisa mesma. Com isso, o entendimento sabe que a diferença entre força e lei, que está presente no primeiro mundo suprassensível, não é a verdade do mundo sensível. Isso porque nele a força e a lei são distintas, quando na verdade não são. A consciência observa um determinado fenômeno e extrai dele seu interior. Neste interior, há a força simples e as diferenças específicas da lei, o primeiro mundo suprassensível. Mas a verdade é que elas não são diferentes. A verdade do mundo suprassensível é seu inverso, ou seja, a lei e a força são o mesmo. Com isso, a verdade torna-se a inversão, o diferenciar do não diferenciado. O fato é que as diferenças não são em si diferenças, e por isso voltam à unidade. Ou seja, a diferença mesma difere de si mesma e faz o que por ela estava posto como diferente tornar-se igual. Por isso nesse ato há tanto o igual a si mesmo, a diferença, que se diferencia também de si, quanto o diferente, a igualdade que se diferencia de si para gerar a diferença. O problema é saber como essa inversão implica a inversão de conteúdo exatamente. 
Ora, o que fica determinado pela inversão descrita por Hegel é que as diferenças entre força e lei não são diferença alguma. Deve-se, portanto, extrair todas as diferenças possíveis dessa tese fundamental para verificar se alguma delas justifica a inversão do conteúdo empírico, como Hegel descreve.

A eletricidade, primeiro mundo suprassensível, estava distinguida, enquanto força simples, de sua lei de ser como positivo e negativo. Mas no mundo invertido essa diferença é nenhuma, e esse mundo é sua verdade mais concreta. Por essa inversão, Hegel afirma que o polo negativo passa a ser positivo, e vice-versa. Ou seja, as diferenças na lei deixam de serem diferenças e passam, portanto, a serem igualdades. Talvez esse seja o ponto. Cada polo da diferença na lei deve tornar-se seu oposto. Essa é a hipótese aqui adotada, mas caberia verificar com cuidado se essa interpretação pode ser aplicada também à relação entre o doce e o amargo, o preto e o branco, a vingança e a autodestruição, o crime e o castigo, etc., todos exemplos apresentados por Hegel no texto.

Para que um polo da eletricidade se converta em seu oposto, é necessário que a diferença que mantinha em relação a ele desvaneça. Sabe-se que a diferença entre força e lei desvanece. Se não há diferença entre força e lei, então as diferenças presentes nesta última não encontram mais base na simplicidade da força. $O$ positivo e o negativo não podem mais ser tomados como desdobramentos de algo simples. Mas o positivo só é mediante o negativo, e vice-versa. Nenhum deles encontra uma essencialidade própria, isolada de seu oposto. Quando um é posto como a essência, exclui de si imediatamente o outro, já que ele não é o outro. Esse é o momento da essencialidade isolada ou ser para si. Mas sua determinação depende de seu oposto. Ou seja, sua base está nele. Por isso, ele deixa de lado sua diferença com ele e passa a ser ele mesmo. Consequentemente, o que inicialmente foi posto como uma essência independente desvaneceu. O positivo torna-se, assim, o negativo. Assim, a lei do mundo invertido, segundo a qual as diferenças entre ser para si (força) e ser para outro (lei) são tais que não são nenhumas, implica a inversão das determinações de cada elemento da lei.

Mas isso é aplicável à relação entre branco e preto, por exemplo? Pode-se supor que Hegel pensa aqui a lei estabelecendo a oposição entre essas cores como condição de sua determinação. Assim, o branco só é branco não sendo o preto, e vice-versa. Quando o branco é posto, imediatamente surge o preto como seu oposto. Pela dissolução da diferença no mundo invertido, a determinação de cada cor deixa de dar-se pela oposição. Assim, cada cor inverte sua determinação: o branco é em verdade o preto, e vice-versa, pois o que determina cada um é seu oposto.

Outro exemplo interessante é a relação entre vingança e autodestruição. A vingança, conforme Hegel, é a lei "[...] segundo a qual devo mostrar-me, como essência, frente a quem não me trata como essência autônoma e, antes, suprimi-lo como essência" (FE, p. 112, § 158). No primeiro mundo suprassensível, essa lei corresponderia à "mais alta satisfação da individualidade ultrajada". Mas "se converte através do princípio do outro mundo no oposto; e a restauração de mim mesmo como essência, mediante a supressão da essência alheia, se converte em autodestruição" (FE, p. 112, § 158). Ou seja, a vingança visa a restituição da individualidade ferida através da destruição violenta do outro. Entretanto, conforme Hegel, ela 
alcança o oposto, a autodestruição. Isso significa que na própria vingança está presente seu oposto.

Poder-se-ia cogitar que o fato na verdade é o seguinte: a vingança visa restituir a dignidade através dos mesmos meios ou a partir da mesma forma como foi ferida. Então, aquele que se vinga torna-se tão indigno quanto aquele que o agrediu. Isto é, ambos não se distinguem em nada. Quando o vingador quer restituir sua dignidade pela vingança, assim, acaba por destruí-la completamente. A vingança era determinada pela sua oposição ao ato injusto. Sem essa oposição, ela se converte nele.

Como último exemplo, pode-se mencionar ainda o caso do castigo ao crime cometido. Aparentemente, ele é a ação da lei sobre o indivíduo que a desrespeitou. Entretanto, é antes seu oposto, pois pelo castigo a individualidade reconcilia-se com a universalidade que desrespeitou antes. Isso porque, no castigo já está posta a sua oposição ao crime. A realização do castigo é consumação de sua unidade com o oposto, que devolve simetria a uma relação desestabilizada pelo crime.

\subsection{A infinitude como verdade do entendimento}

Desse modo, o mundo invertido é a representação da essência como um oposto. Isso significa que cada elemento só é ele mesmo quando é também seu oposto. Por isso pelo mundo invertido está representado o movimento absoluto, ou seja, não o ir de um elemento a outro, mas o movimento que move a si mesmo, o ser para si que é enquanto tal também ser para outro. Cada coisa é, na sua igualdade consigo mesma, seu oposto. Hegel esclarece esse difícil conceito da seguinte forma:

\footnotetext{
Com efeito, na diferença, que é uma diferença interior, o oposto não é somente um dos dois - aliás seria um essente, e não um oposto; mas sim o oposto de um oposto, ou seja, nele está dado imediatamente o Outro. Ponho, na certa, o contrário do lado de cá; e, do lado de lá, o Outro de que é contrário; portanto de um lado, o contrário em si e para si sem o Outro. Mas, justamente porque tenho o contrário em si e para si, é o contrário de si mesmo, ou seja, já tem de fato o Outro imediatamente em si mesmo (FE, p. 114, § 160).
}

Essa é uma nova forma de a consciência conceber o ato de diferenciação que determinava os momentos da lei. Ao invés de pôr uma identidade que deve fracionar-se nas diferenças, são as próprias diferenças que, em cada um de seus pólos, estabelecem a identidade a partir das quais se diferenciam. Cada oposto tem o outro em si, na medida em que é oposto, e por isso determina sua diferença em relação a ele.

A essa diferença que é autossuficiente, no sentido de conter em si o ser outro pelo qual é diferença determinada, Hegel chama de infinitude. Para ele, "nós vemos que, graças à infinitude, a lei cumpriu-se em si mesma como necessidade, e que todos os momentos do fenômeno foram recolhidos ao interior" (FE, p. 114, § 161). Nada mais resta ao fenômeno que não esteja presente no mundo suprassensível. O suprassensível, agora invertido, infinito, não é apenas a esfera da identidade oposta às diferenças que se manifestam nos fenômenos. Ele contém agora o diferenciar-se, enquanto um movimento contido em cada diferença efetiva. 
$\mathrm{Na}$ infinitude, unidade e multiplicidade, identidade e diferença, estão suprassumidas uma na outra. Essa ideia permite a Hegel reinterpretar o clássico problema da relação entre uno e múltiplo.

Costuma-se dizer que a diferença não pode brotar da unidade; mas de fato a unidade é apenas um momento de fracionamento, é a abstração da simplicidade que defronta a diferença. Mas por ser abstração, é só um dos opostos, como já se disse. Ela é o fracionar-se, pois a unidade é um negativo, um oposto; assim é posta justamente como o que tem nele a oposição (FE, p. 115, § 162).

O real, o efetivo, é a unidade entre a identidade e a diferença. Mas a consciência natural concebe a identidade e a diferença como elementos simplesmente opostos. A questão é que cada um deles só se determina pela oposição ao outro. Então, esta unidade de fundo é anterior e condição para cada um. A identidade é um movimento que parte da diferença e a reduz a uma unidade. Da mesma forma, quando se estabelece diferenças, vai-se da unidade à multiplicidade. No conceito de infinitude, fica evidente em cada um desses extremos sua identidade com o outro, que no mundo invertido faz com que cada um se converta no seu oposto.

A infinitude, que é a verdade do entendimento, foi alcançada a partir da dissolução de seus momentos, o ser para si (identidade) e o ser para outro (diferença), que ocorreu pelas experiências do entendimento. $E$, na verdade, a infinitude é exatamente essa dissolução posta como verdade. Isso significa que, em todas essas experiências, o que o entendimento realmente experimentou foi a si mesmo, no sentido de que se tornou consciente das determinações que o constituem desde sempre. Como afirma Hegel, "[...] de fato, o entendimento só faz experiência de si mesmo" (FE, p. 117, § 165).

Mediante esse aprendizado, o entendimento eleva seu ponto de vista, fazendo com que a consciência seja capaz de tomar a si mesma como seu objeto, sua verdade.

\footnotetext{
Enquanto esse conceito de infinitude se tornou seu objeto, ela é pois consciência da diferença como de uma diferença também imediatamente suprassumida: a consciência é, para-si-mesma, o diferenciar do não-diferenciado ou consciência-de-si. Eu me distingo de mim mesmo; mas este diferente, este posto-como-desigual, é imediatamente, enquanto diferente, nenhuma diferença para mim (FE, p. 117, § 164).
}

$\mathrm{Na}$ autoconsciência, a diferença entre o eu e seu objeto é posta e imediatamente suprassumida, já que o objeto é o próprio eu. A consciência de si, assim, é infinita, no sentido de que os polos do eu e do objeto estão nelas como suprassumidos. E o conteúdo dessa consciência, na medida em que é fruto de um ato de diferenciação do eu, revela sempre a unidade com seu oposto, que em última instância é sempre a consciência mesma. Nesse ponto, o entendimento converte-se em consciência de si. 


\section{CONCLUSÃO}

Pelo que foi demonstrado, a crítica de Hegel a Kant está relacionada à elaboração da Fenomenologia do espírito de duas maneiras. Em primeiro lugar, ela mostra porque não se pode estabelecer o âmbito de legitimidade do conhecimento, ancorando a análise em algum tipo de elemento externo ou anterior à determinação desse âmbito, e porque desta constatação surge a necessidade de uma Fenomenologia do espírito. Em segundo lugar, a crítica de Hegel a Kant antecipa, em linhas gerais, o modo como a consciência tematiza seu saber ao longo do processo exposto pela Fenomenologia.

O ponto central do trabalho de Hegel, a partir do ponto de vista adotado aqui, consiste em mostrar que a crítica de Kant só é possível mediante a aceitação tácita de certas noções a respeito do sujeito, de sua faculdade cognitiva e do próprio objeto. Consequentemente, a legitimidade de suas conclusões depende da legitimidade desses elementos, já que estes são pressupostos daquelas. O problema é que, enquanto posta como instância fundamentadora, somente a investigação crítica, a partir de seus resultados, dispõe do critério de legitimação da qualquer saber. Porém, esse critério não pode ser utilizado para fundamentar aqueles elementos, pois ele mesmo é extraído a partir deles. E, como não resta outra instância de fundamentação a esses pressupostos, torna-se necessário concluir que a fundamentação crítica do saber só é possível pela aceitação acrítica de certos conhecimentos. Com isso, a crítica converte-se em seu oposto, ou seja, em aceitação dogmática de um conteúdo dado.

Por um lado, essa conclusão abre espaço a uma obra tal como a Fenomenologia do espírito, em que a ciência aparece à consciência enquanto esta tematiza seu saber. Se a tentativa de Kant tivesse obtido êxito, a tarefa de fundamentação estaria concluída, restando à consciência apenas a tarefa de guiar-se rigorosamente pelo critério de cientificidade estabelecido. Neste caso, não faria sentido dar algum valor a uma consciência que está ainda envolvida no saber aparente. O que se deveria fazer é mostrar a ela o verdadeiro conceito de ciência, para que ela pudesse adotá-lo e assim abandonar suas ilusões. Entretanto, conforme o argumento hegeliano, não é possível estabelecer previamente o caminho que leva ao saber científico, pois essa determinação estaria sempre na dependência de certos pressupostos baseados em pontos de vista anteriores ao aparecimento da ciência e, consequentemente, impossíveis de serem validados sem levar, nisso, ao um círculo vicioso. A única forma de evitar essa situação é fazer com que os pressupostos de que se parte possam ser considerados também científicos. Isso, por sua vez, desloca a tarefa de fundamentação de um ponto anterior à ciência para o interior dela mesma. Em outras palavras, a ciência só poderá ser fundamentada quando o saber de que se parte para isso for ele mesmo científico. Resta à consciência que ainda não se tornou ciência, portanto, não mais a tarefa de fundamentá-la, já que isso lhe é impossível, mas a de implementá-la a partir dos elementos de que dispõe. Se 
não há outro caminho à ciência do que sua implementação efetiva, desenvolvida por uma consciência que ainda não a conhece, então o saber dessa consciência acaba tendo de ser encarado como o aparecer da ciência, por meio do qual ela vem a ser o que é verdadeiramente. Esse é justamente o processo a ser exposto pela Fenomenologia do espírito.

Mas, a conclusão mencionada também tem outro significado. Ela diz algo sobre o modo como se desenvolve o objeto exposto pela Fenomenologia. Mais precisamente, ela indica como é possível à consciência tornar-se ciência a partir de seu saber aparente. A questão é que na crítica de Hegel a Kant fica saliente o fato de que um determinado saber só pode ser avaliado a partir dos elementos que estão em jogo nele mesmo. O apelo a um fundamento externo é um engano. Não porque esse fundamento seja incorreto. O fato é que tal exterioridade não é possível. O saber elaborado por Kant, segundo o qual a ciência tem seu âmbito de legitimidade restrito ao fenômeno, deveria ser encarado como um momento singular, em que se desenvolve a pergunta sobre as condições de possibilidade do conhecimento, e não como a efetivação de um ato cognitivo propriamente dito, cuja legitimidade deveria ser avaliada. Quer dizer, Kant não quer depender de qualquer qualificação a respeito dos objetos a serem conhecidos ou do sujeito conhecedor. Ele quer que sua interrogação diga respeito apenas àquilo que se deve pressupor como necessário para a elaboração de todo conhecimento. Portanto, ele imagina estar ancorando sua análise num elemento que está aquém de qualquer saber efetivo e, por isso, está igualmente aquém da pergunta a respeito de sua validade. Justamente por ser esta a pressuposição basilar de Kant, é ela também o primeiro alvo da crítica de Hegel. Sua estratégia consiste em mostrar que há sim conhecimentos implicados na pergunta kantiana. Perguntar sobre as condições subjetivas do conhecer significa tomar como certas determinadas noções a respeito do que seja o conhecimento, o objeto a ser conhecido e a própria faculdade cognitiva. Então, não é possível considerar a pergunta sobre a fundamentação da ciência como algo externo ao desenvolvimento efetivo do saber científico, pois o que se tem aí não é nada mais do que certo conteúdo cuja legitimidade precisa ser avaliada. Ou, dizendo o mesmo de outra forma, não é possível elevar-se imediatamente para fora de um determinado saber até um ponto indiferente a ele a partir do qual tudo mais pode ser julgado; pois nessa tentativa não se vai além do que está pressuposto desde o início no próprio saber em questão.

Essa argumentação na verdade inaugura o ponto de vista que se deve adotar na elaboração da Fenomenologia do espírito. A consciência aí apresentada deve ser tomada a partir dos elementos de que ela mesma dispõe. Para ela, seu saber é legítimo porque se apossa de uma verdade anterior e autônoma em relação a ele. A rigor, esta constatação impede o desenvolvimento do processo fenomenológico, pois nele é necessário que a consciência avalie seu saber, o que é impossível se a verdade for considerada um elemento oposto e exterior a ela. A crítica a Kant mostra que aquilo que é tomado como base do saber no fundo é também ele um saber. A princípio, como se mostrou, isso simplesmente refuta a ideia de que é possível dispor de um elemento imune aos possíveis defeitos do saber e, por isso mesmo, capaz de fundamentá-lo adequadamente. Mas, olhando mais de perto, isso permite conceber o processo pelo qual a consciência, que não conhece a verdade, procura certificar-se do saber que possui de outra forma. Para Kant, como se mostrou simploriamente, 
era necessário encontrar um caminho seguro à elaboração posterior do saber científico. Esse caminho deveria ser traçado a partir de um critério rigorosamente definido. Para a elaboração desse critério, por sua vez, ele forneceu uma hipótese: ideia de que o conhecimento científico só é possível a partir de certas condições subjetivas a priori. A validade dessa hipótese dependeria simplesmente dos resultados obtidos mediante sua aplicação sobre os problemas da metafísica clássica. Para Hegel, entretanto, o que está em jogo aí não é apenas isso. $\mathrm{Na}$ verdade, não se trata de uma consciência que num dado momento experimenta a aplicação de certo modo de pensar o conhecimento e que, a partir dos resultados desse ato, constata se encontrou ou não o caminho da ciência. No fundo, o que está em jogo aí é um determinado conjunto de conhecimentos - os conceitos de sujeito, objeto, conhecer, etc. Tudo que ocorre não é nada mais do que o desenvolvimento dos elementos intrínsecos ao próprio saber e diferenciados no seu interior. O que cabe observar, consequentemente, não é apenas o desdobramento de certo pressuposto e o resultado de sua aplicação, pois nisso não ocorre o que é realmente exigido: a fundamentação do saber. É preciso ver o processo pelo qual a consciência avalia seu saber na forma de uma autotematização. Assim, o que surge como verdade terá de ser visto como o desdobramento das tensões intrínsecas àquilo que está posto no saber da consciência desde o início.

A partir dessa visão ampla sobre o projeto hegeliano, o presente trabalho reconstruiu as três figuras da consciência: a certeza sensível, a percepção e o entendimento. Tentou-se interpretar as experiências presentes em cada uma delas enquanto autocríticas da própria consciência fenomenológica.

$\mathrm{Na}$ certeza sensível, a consciência buscava a essência na pura singularidade. Entretanto, ao lado de cada singular surgia outro, ou seja, cada ser era ao mesmo tempo um não ser. Por exemplo, a verdade é o singular de que se está diante: esta casa. Mas também pode-se ter diante de si uma árvore. Nesse caso, ter-se-ia duas essências, já que nas duas situações trata-se de singularidades. Pelo fato de uma ser diferente da outra, fica determinado que uma não é a outra. Como se trata de dois seres, um ser não é o outro, isto é, enquanto um é tomado como ser, o outro tem de ser um não ser. Ou seja, se são ambos singulares, ambos tem de ser essências, mas se um "é" o outro não "é". Consequentemente, a singularidade não pode ser a base da essencialidade, pois por ela está dito também exatamente o oposto, ou seja, que o singular não é o essencial, já que quando um singular é tomado como ser os outros tem de ser negados como essencialidades. Isso significa que a singularidade desvanece como essência. Pelo caráter necessário dessa experiência, ela assume também um papel positivo em relação à verdade, que não é nada mais do que o que está dito por ela em seu sentido negativo. Pela experiência fica determinado que o singular não é o essencial. Então, o essencial é justamente esse desvanecer da singularidade. Quando se diz que a singularidade é o essencial, não se está tomando um singular como essente mas antes um universal. Isso é o que faz com que todo singular desvaneça. A singularidade não é esta casa ou esta árvore, embora tanto a casa quanto a árvore sejam singulares. Da mesma forma, quando se toma a casa como uma essência, não se está falando desta ou daquela casa, mas sim, com o perdão do termo, da "caseidade", da casa em sua universalidade.

Isso é o que fica descoberto pela experiência de tomar um singular como essente e verificar que, ao lado dele, surgem também outros singulares da mesma forma essenciais: o 
essencial é um conjunto de singulares e, por isso, os singulares só são seres na medida em que estão embasados em uma universalidade.

Nesse momento, a consciência passa da certeza sensível à percepção. A essência agora é o universal. Ora, o singular não pode ser a essência porque ao lado dele sempre surge algo da mesma forma singular, portanto com o mesmo "direito" de ser a essência, e ao mesmo tempo diferente. Esta casa é diferente (não é) aquela casa, mas ambas deveriam ser essenciais, pois as duas são singulares. Pelo universal, justamente esse problema é solucionado. A casa enquanto tal não tem ao seu lado outra casa, pois toda casa singular já está contida na casa em sentido universal. Isso significa que na universalidade atinge-se o ponto em que toda diferença, todo ser outro, é suprassumida na simplicidade da essência. Assim, ao lado do que é tomado como essência não pode surgir algo outro que negue a primeira em seu ser essencial, como ocorria na certeza sensível. Por isso a percepção toma por tarefa apreender o real em sua igualdade consigo mesmo, de que toda diferença como diferença efetiva está excluída. Não pode haver diferença naquilo que é tomado como verdade, pois toda diferença nada mais é do que um elemento singular que já deve estar presente no universal e, portanto, já não pode mais ser diferença efetiva.

Quando, na percepção da coisa em sua universalidade simples, surgirem diferenças efetivas, que escapam à simplicidade da essência, é preciso supor que há uma falha no perceber, quer dizer, uma ilusão; pois pela universalidade, que é a verdade na percepção, está dito que a essência é simples, de modo que em relação a ela não há diferença alguma, justamente porque ela já tem em si reunidas todas as diferenças.

A verdade agora é a coisa de muitas propriedades. Por isso ela tem de assumir duas tarefas. Por um lado, ser simples, ou seja, reunir todas as propriedades numa unidade. Por outro, ser determinada, distinguindo-se das demais coisas. De acordo com a primeira exigência, as propriedades estão na coisa como elementos indiferentes entre si. Todas estão no mesmo "lugar" sem que uma interfira nas outras. Mas de acordo com a segunda exigência, as propriedades devem ser distintas umas das outras. O sal, por exemplo, só é ele mesmo, diferenciando-se de todas as outras coisas, na medida em que possui propriedades específicas. Para isso, o branco tem de estar nele de tal forma que possa distinguir-se do sabor salgado. Nesse caso, a coisa tem de ser considerada mais propriamente uma multidão de propriedades entre si opostas.

Com isso, surge no perceber uma diferença: a coisa é una e ao mesmo tempo múltipla. Para a consciência, isso não é possível, pois a verdade como universal é a suprassunção de toda diferença numa unidade. A diferença enquanto diferença efetiva não pode estar presente. As propriedades deveriam, assim, ser determinadas e ao mesmo tempo indiferentes entre si. Entretanto, com isso não se tem nada além do que as puras singularidades da certeza sensível. A consciência sabe, em todo caso, que o objeto como universal é o verdadeiro a partir da experiência da certeza sensível. Então, a falsidade que surge só pode ser fruto do próprio perceber, e a consciência novamente põe o objeto como coisa de muitas propriedades, assumindo para si a desigualdade que possa surgir nele.

Como universal, a coisa tem de ser uma unidade simples. Mas também estão presentes as múltiplas propriedades. Se fossem realidades efetivas diversas, fariam da coisa uma multiplicidade. Então a consciência deve assumir isso como efeito seu. A coisa é uma, e 
a multiplicidade de propriedades está presente apenas no perceber. Mas a coisa mesma só é determinada se tem propriedades distintas. Isso significa que nela mesma é necessário que existam as diversas propriedades opondo-se mutuamente. Consequentemente, a coisa é antes uma multiplicidade de propriedades e a unidade é que deve ser assumida pela consciência. Por essa experiência, fica claro para a consciência que as duas exigências estão ligadas à objetividade: a coisa deve ser uma unidade e, ao mesmo tempo, uma multiplicidade. As propriedades têm de estar todas numa mesma coisa, para que não se tenha simplesmente uma porção de elementos singulares, e têm de opor-se entre si, sem o que não seriam determinadas.

Mas, com isso, a coisa torna-se diferente de si mesma. Ora, isso não é possível para a percepção. Então ela divide os momentos entre coisas distintas. A coisa é una, na medida em que suas propriedades só existem como propriedades da coisa e assim coincidem quanto à essência. A oposição mútua entre elas só surge quando a coisa se relaciona com algo outro que ela (uma outra coisa). Ou seja, em relação a si mesma, a coisa é uma unidade simples. A multiplicidade só surge quando ela precisa distinguir-se das demais. Assim, a unidade é o ser para si, enquanto a multiplicidade é o momento do ser para outro. Com isso, a coisa enquanto tal, em seu ser para si, permaneceria igual a si mesma. A multiplicidade seria apenas o momento da relação com outro (ser para outro). Entretanto, a determinidade, que só é alcançada pelo momento do ser para outro, também é necessária à coisa, como tornou-se evidente. Então, na coisa, tomada apenas na simplicidade de seu ser para si, está posta também a necessidade do ser para outro. Isso significa que os dois momentos são intrínsecos à própria objetividade. Ou seja, na consideração da verdade é preciso tomar os momentos do ser para si e do ser para outro numa unidade. Nesse momento, a consciência deixa de ser percepção para tornar-se entendimento.

Para o entendimento, a verdade é o universal incondicionado, a unidade entre ser para si e ser para outro. O fato é que a universalidade da percepção surgiu como volta das diferenças, de que partiu a certeza sensível, à unidade de uma essência permanente. Com isso, a determinação fundamental da coisa torna-se a igualdade consigo mesma, que só pode implementar-se pela suprassunção de toda diferença. Justamente por isso, em relação a ela nenhuma diferença poderia existir. Foi por isso também que o momento da determinação da coisa, em que ficam evidentes os elementos específicos que a compõem, teve de ser considerado, por diversas formas, um outro em relação à coisa em sua simplicidade. A esse tipo de universalidade poder-se-ia dar o nome de universal condicionado, já que o universal do entendimento o supera exatamente por ser incondicionado. $\mathrm{E}$ a condicionalidade do universal da percepção está justamente no fato de que sua determinação é um outro que ele, isto é, a coisa de muitas propriedades depende (está condicionada) de um outro para determinar-se, para ser ela mesma.

O entendimento surge exatamente quando o momento da oposição com outro é assumido como constituinte da mesma essência. Por isso, o entendimento toma como princípio de seu objeto a universalidade incondicionada, ou seja, um universal que tem em si mesmo também a condição de sua determinação - o ser para outro, as múltiplas diferenças.

Dessa forma, a consciência se torna entendimento justamente ao dar-se conta de que o objeto em sua simplicidade e universalidade só é ele mesmo quando assume também a 
forma de múltiplas determinações, pois só assim se distingue de todas as demais coisas. Por isso, no entendimento a objetividade vai ser considerada a partir da unidade entre ser para si e ser para outro, ou seja, entre o objeto em sua identidade consigo mesmo e as múltiplas diferenças presentes nele. Essa identidade, por sua vez, tem seu caráter determinado pelo próprio modo como os momentos desvaneceram no seu isolamento. A coisa como uma unidade desvaneceu porque a diferenciação the era necessária e por isso deveria ser o essencial. Da mesma forma, a coisa como meio de matérias livres desvaneceu, pois a independências das matérias não era nada mais do que a unidade da coisa. Assim, o momento em que os dois aspectos da coisa estão presentes é o do movimento de um a outro, em que cada um se converte no que deveria ser o oposto em relação a ele. É isso, então, o que deve ser o essencial: o movimento entre a unidade e a diferenciação, que recebe o nome de força. A força enquanto tal, na simplicidade de sua essência, é a força recalcada em si - o momento da unidade. O outro momento é o da força desdobrada, em que todas as diferenças estão presentes enquanto diferenças.

A força enquanto tal é, assim, ela no seu recalcamento em si, quer dizer, enquanto una. Consequentemente, o desdobramento é para ela outra essência. Mas enquanto força, o desdobramento é igualmente essencial. Então, a partir da força como tal fica determinado que o desdobramento é essencial à força.

Com isso, o desdobramento passa a ser a essência da força. Contudo, o desdobramento só é possível a partir de uma essência recalcada. Assim, a essência da força deve ser antes sua unidade. Fica claro para a consciência que são essenciais à força tanto a oposição que há entre as forças recalcada e desdobrada, quanto a relação necessária que há entre elas, que faz com que uma desvaneça diante da outra.

Mostrando-se inevitável, o jogo entre essas forças revela o caráter evanescente do real. Ele passa a ser concebido, por isso, como fenômeno, aparência. Sua essência está para além dele, no mundo suprassensível. Nele estão contidas as leis que governam as múltiplas relações entre os seres materiais. Embora estes desvaneçam constantemente, as leis mesmas são imutáveis.

Mas isso revela uma dificuldade: como o mundo suprassensível pode ser a essência do mundo fenomênico, se a multidão de diferenças que existe neste não pode estar presente naquele, já que é a esfera das leis simples, iguais a si mesmas? Multiplicando as leis, por outro lado, volta-se ao desvanecer das diferenças umas nas outras.

A solução do entendimento é conceber o mundo suprassensível como tensão entre lei e força. As leis explicariam as diferenças, as oposições do mundo fenomênico, e a força faria essas leis retornarem à unidade.

Mas nada é explicado aqui. A força, como a unidade, o ser para si, permanece indiferente à lei, que é o ser para outro, a diferenciação. Não fica demonstrado porque a força deve diferenciar-se nas leis, nem porque as leis devem unificar-se na força.

A dissolução da lei e da força enquanto momentos isolados e ainda assim essenciais, por fim, faz surgir um segundo mundo suprassensível, oposto em relação ao primeiro. Nesse mundo invertido, a unidade será concebida com o outro da diferença, e vice-versa. A identidade entre ambas será denominada infinitude. Nesse momento, o entendimento compreende que as diferenças que impõe aos objetos que tematiza são frutos de um 
movimento que parte dele mesmo. É ele que conhece a si mesmo e se diferencia, sendo ainda ele mesmo nesse diferenciar. Nesse momento, a consciência converte-se em consciência de si. 


\section{REFERÊNCIAS}

\section{OBRAS DE HEGEL EM PORTUGUÊS}

HEGEL, G.W.F. Enciclopédia das ciências filosóficas em epítome. Trad. de Artur Morão. Lisboa: Ed. 70, 1988. 3.v.

HEGEL, G.W.F. Fenomenologia do espírito (Prefácio, Introdução e Cap. I e II). Trad. de Henrique Cláudio de Lima Vaz. São Paulo: Abril Cultural, 1974.

HEGEL, G.W.F. Fenomenologia do espírito. Trad. de Paulo Meneses. Petrópolis: Vozes, 1992. 2.v.

HEGEL, G. W. F. Discursos sobre educação. Trad. Ermelinda T. Fernandes. Lisboa: Colibri, 1994.

HEGEL, G. W. F. Propedêutica filosófica. Trad. Artur Morão. Lisboa: Edições 70, 1989.

HEGEL, G. W. F. Filosofia do direito. Tradução de Paulo Menezes. São Paulo: Loyola, 2010.

\section{OBRAS SOBRE A FENOMENOLOGIA DO ESPÍRITO EM PORTUGUÊS}

HYPPOLITE, J. Gênese e estrutura da Fenomenologia do espírito de Hegel. Trad. de Sílvio Rosa Filho (Coord.). São Paulo: Discurso Editorial, 1999.

MENESES, P. Para ler a Fenomenologia do espírito - Roteiro. Ed. Loyola: São Paulo, 1985.

SANTOS, J. H. Trabalho e riqueza na Fenomenologia do espírito de Hegel. São Paulo: Loyola, 1993. 


\section{OBRAS SOBRE HEGEL E DIALÉTICA EM PORTUGUÊS}

AQUINO, M. O conceito de religião em Hegel. São Paulo: Edições Loyola, 1989.

BICCA, L. O conceito de liberdade em Hegel. In: Rev. Síntese Nova Fase, Belo Horizonte, vol. 19 , n. 56,1992 , p. 25-47.

CHAGAS, E. F.; UTZ, K.; OLIVEIRA, J. W. J. Comemoração aos 200 anos da 'Fenomenologia do espírito' de Hegel. Fortaleza: Editora da Universidade Federal do Ceará, 2007.

CHÂTELET, F. O pensamento de Hegel. Trad. de Lemos de Azevedo. 2 ed. Lisboa: Editorial Presença, 1985.

CIRNE-LIMA, C. Dialética para principiantes. Porto Alegre: EDIPUCRS, 1996.

CIRNE-LIMA, C. Sobre a contradição. Porto Alegre: EDIPUCRS, 1993.

FEUERBACH, L. Princípios da Filosofia do futuro. Lisboa: Ed. 70, 1988.

FLICKINGER, H. Marx e Hegel: o porão de uma filosofia social. Porto Alegre: L\&PM; CNPq, 1986.

GARAUDY, R. Para conhecer o pensamento de Hegel. Trad. de Suely Bastos. Porto Alegre: L\&PM, 1983.

HÖSLE, Vittorio. O sistema de Hegel: o idealismo da subjetividade e o problema da intersubjetividade. Tradução de Antonio C. Pinto de Lima. São Paulo: Loyola, 2007.

INWOOD, M. Dicionário Hegel. Trad. de Álvaro Cabral. Rio de Janeiro: Jorge Zahar Editor, 1997.

KAUFMANN, W. Hegel. Trad. de Victor Sánchez de Zavala. 4 ed. Madrid: Alianza Editorial, 1985.

LUFT, E. As sementes da dúvida: investigação crítica dos fundamentos da filosofia hegeliana. São Paulo: Mandarim, 2001.

LUFT, E. Para uma crítica interna ao sistema de Hegel. Porto Alegre: Edipucrs 1995.

LUKÁCS, G. Ontologia do ser social: a falsa e a verdadeira ontologia de Hegel. Trad. de Carlos Nelson Coutinho. São Paulo: Livraria Editora Ciências Humanas, 1979.

MARCUSE, H. Ontologia de Hegel. Trad. de Manues Sacristán. Barcelona: Ediciones Martínez, 1983. 
MARX, K. Crítica da Filosofia do Direito de Hegel. Trad. de Conceição Jardim e

NOBREGA, F. P. Compreender Hegel. São Paulo: Loyola, 2009.

OLIVEIRA, M. A. A liberdade como síntese de opostos: transcendência, engajamento e institucionalidade. In.: Rev. Véritas, Porto Alegre, vol. 44, n. 4, dez de 1999, p. 1019 a 1040).

OLIVEIRA, M. A. Tópicos sobre dialética. Porto Alegre: EDIPUCRS, 1996. (Coleção Filosofia, $\left.n^{\circ} 51\right)$.

STEIN, E. e DE BONI, L (Org). Dialética e liberdade - Festschrift em homenagem a Carlos

Roberto Cirne-Lima. Petrópolis: Vozes; Porto Alegre: Editora da Universidade Federal do Rio Grande do Sul, 1993.

\section{OUTRAS REFERÊNCIAS}

COLOMER, E. O pensamento alemão de Kant a Heidegger. Barcelona: Editorial Herder, 1986.

HARTMANN, N. A filosofia do Idealismo Alemão. Trad. de José Gonçalves Belo. Lisboa: Fundação Calouste Gulbenkian, 1976.

KANT, I. Crítica da Razão Pura. 3. ed. Lisboa: Fundação Caloustre Gulberkian, 1994. 
